$$
4 x-121
$$

Feasibility Studies of the Partitioning of Commercial High-Level Wastes Generated in Spent Nuclear Fuel Reprocessing: Annual Progress Report for FY-1974
W D Bond
P E Leuze 


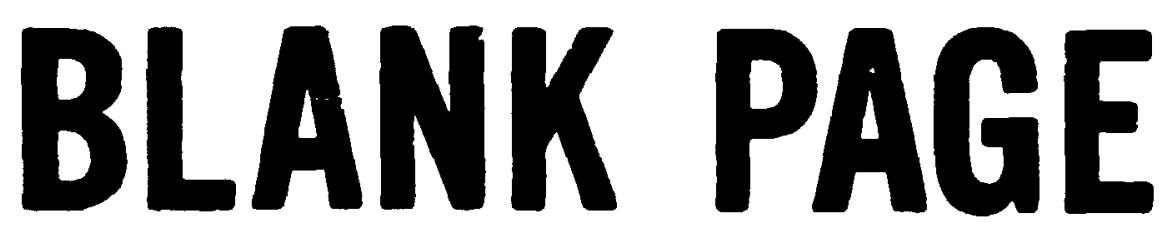


Printed in the Unitud Stabs of Ameriea Avaibute from Nationd Tex wiod informotion Service

US. Depertment of Coconere

5206 Port Rord Row. Spring feld. Virginia 22161

Price: Arinted Copy S5.65: Mionofiche 2.25

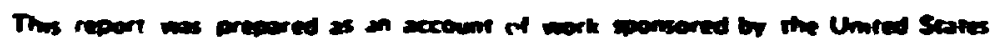

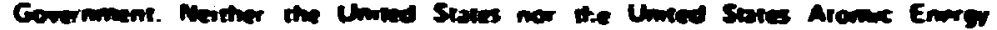

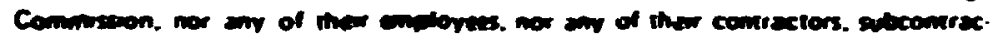

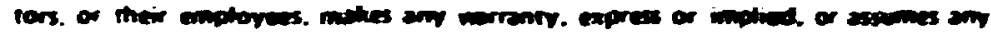

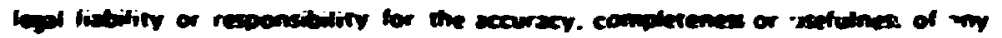

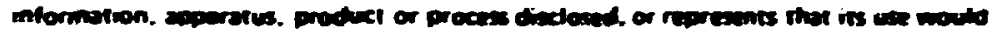

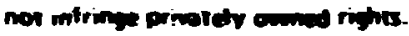


$0.12-5012$

UC-70 - Wace Vinevent

Contract Do. W-7405-eng-26

CEAICAL IECEDLOT DIVISIOA

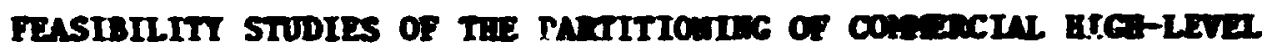

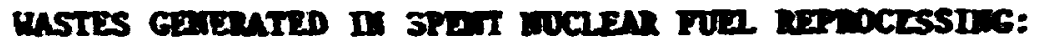

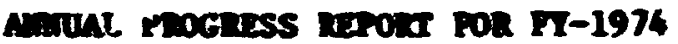

U. D. Bond and 2. E. Levese

Contributios by:

J. 0 . Blonke

D. 0. Capbell

H. C. Clatborme

F. A. Kappelonan

F. G. Rites

L. E. Horse

B. Weaver

\section{JANUARY 1975}

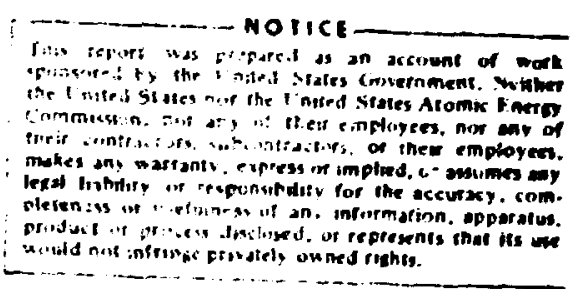

OAK RIDGE NATIOKAL LADORATORY

Oak RAdge, Tennescee $\mathbf{3 7 8 3 0}$

operated by

isson CARBIDE CORPORATIOA

for the

U.s. ATOMIC ENergy COMission 
matuts

Anetret .......................... I

1. Introhnetion ..................... 1

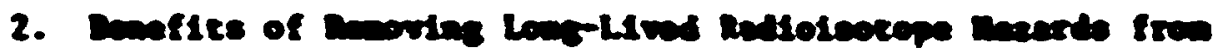

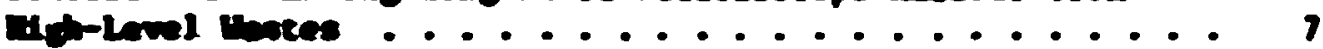

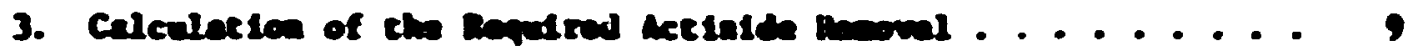
3.1 Laste of Calculations . . . . . . . . . . . . S

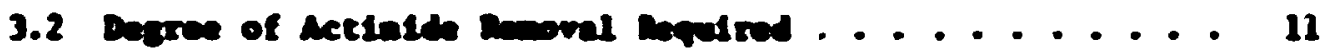

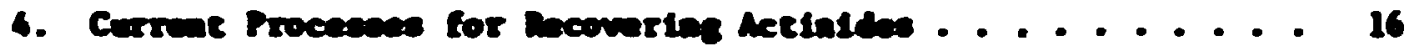

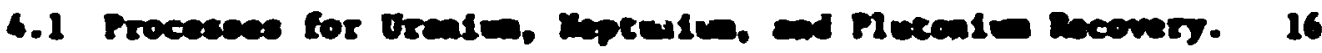

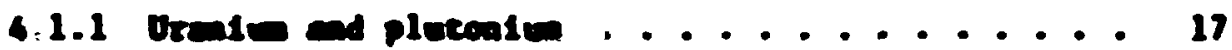

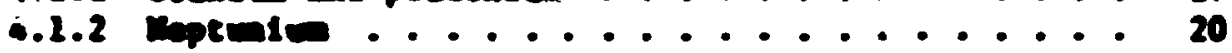

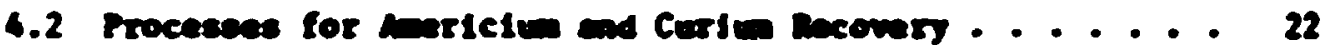

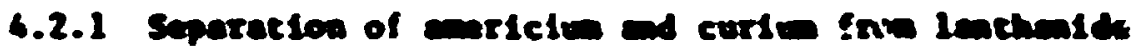
flocion probuces . . . . . . . . . . . 23

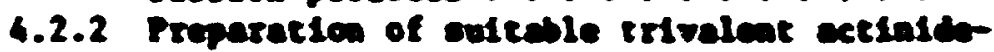

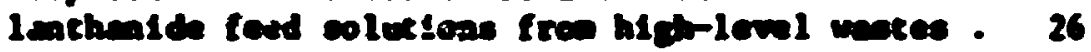

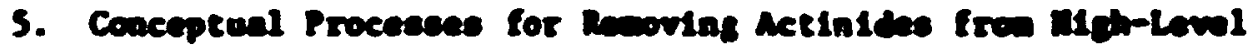

Werte. . . . . . . . . . . . . . . . . 35

S.1 Proceastog Sequence . . . . . . . . . . . . 35

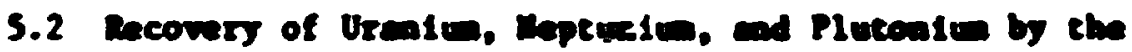
Purex Proceses in the Fuel Roproceseder Plase ...... 37

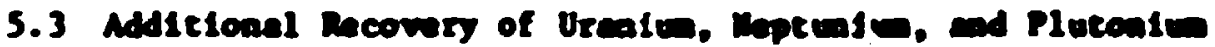
by Echoustive Extraction ............. 30

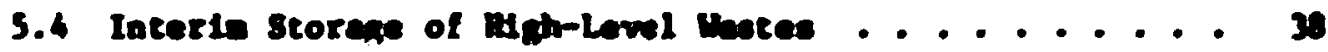

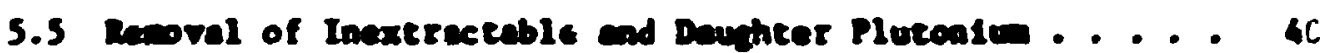

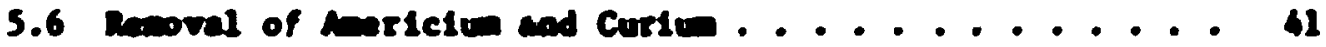

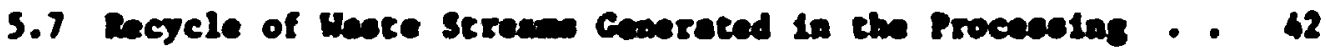

6. Hajor Problen to se solved ... . . . . . . . . . . 43

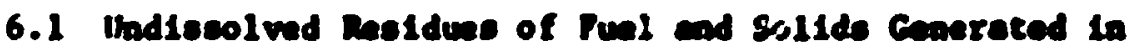
the Proceaslns .................. 43

6.2 Inoxtractable plutoalú . . . . . . . . . . . 4s

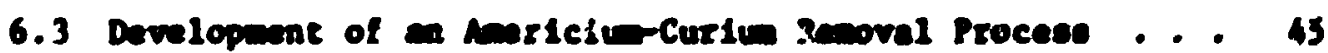


6.4 Altern-1ive Eeducteats for Branin, Deptonion, and Plutonion Partitioniag . . . . . . . . . . . . 46

6.5 Jantrol of Eeptonion Dalence in Coextraction . . . . . 48

6.6 Kecycle of Uncte Stren . . . . . . . . . . . 49

7. Laboratory Studies on Process Developmeat ........... 51

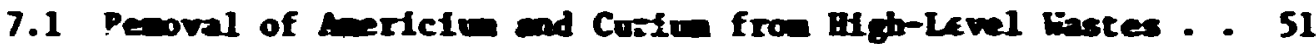

7.1 .1 Solvent extraction process ecthods ....... 52

7.1 .2 Ion exchnage process methods .......... 59

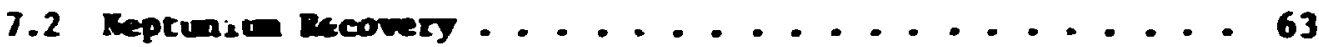

7.2.1 Purex process and nomeaclature und ....... 63

7.2.2 Coextraction of neptontion, oranien, and plutonien (BA colon) ................. 63

7.2.3 Partitioaing step (colu Bis) .......... 66

7.2.4 First uranto purification cycle . . . . . . . 11

$7.2 .5 \mathrm{~V}(\mathrm{IV})-\mathrm{I}_{2} \mathrm{H}_{4}$ as a reductant for aeptuaiun...... 71

8. Conceptual Flowsheet Studies on Recycle in tine Purex Process. - 75

9. Sumary ...................... 82

10. Appendixes .................... 85

10.1 Appendiz A: Hazard Iadex Values for the Major Component: oi Unprocessed Spent Puels from the Principal Reactor Types .... . . . . . . . . . . . . 85

10.2 Append:x B: Calculation of the Hazard Inderes of Uraniul Miserals . . . . . . . . . . . . . 91

10.3 Appendix C: Relative Contributions of the Mafor Components of High-Level wate from Conventional Reprocessing of Uresium-riutonitu Fuels and from Assuned Secondary Processing of the Vlaste . . . . . . . 93

104 Appendix D: Relative Contribution of Each Long-Lived Fission Product to the Total Hazard Index of Pission Products in High-Level lastes.............. 97

10.5 Appendix E: Preparation of Synthetic Waste Solutions. . 99

11. References .................. 103 
FEASIBILITY STUDIES OF THE PARTITIONING OF COAERCIAL HIGH-LEVEI. UASTES GENERATED IN SPENT NUCLEAR FUEL REPEOCESSIYG: ANTUAL PROGRESS REPORT FOR FY-1974

H. D. Bond and R. E. Leuze

\section{ABSTRACT}

The feasibility of renoving long-lived actinides from high-level waste has been evaluated on a prel ininary basis. Results indicate that it asy be possible to rewve actinides to a sufficiently low level to decrease the potential nazard of high-level raste at 1000 years to a value comarabl z to that of naturally occurring uraniu minerals. The feasibility study vas directed primarily at high-level vaste generated iy the comerciai reprocessing of LWR fuel. Although certain separations processes have the potential for the necessary actinide removals (up to $10^{4}$ on a sp.nt-fuel basis), they have not been applied to the particular problew of separations fron waste solutions. A research and develcpment progran of constderable depth is required to deterwine whether these separations processes can be successfully modified and adapted to achieve the necessary separations and, in turn, be integrated into a fuctional raste processing facility at the expected levels of radioactivity. Data obtained in studies carried oxt thus far indicate that the wost pronising concept for achieving the jeafred removals of actinides will require ilproved recovery of actinides in conventionai reprocessing of fuels as well as secondary processing of the waste. Potentfal frocesses for the necessary actinide removals were studied, and several problese that must be solved to develop satisfactory process flowshe sts were identified. Present laboratory studfes are cesigned to pinpoint the advantages of various prowing potential processes and to resolve some of the difficult chentcal problens.

\section{INTRODUCTION}

The Waste Partitioning Program was inftiated in FY-1974 by the U.S. Atondc Energy Comission (USAEC). The objective of this program is to determine the technicsl and economic feasibility of ramoving the potentially hazardous very long-lived (>1000 years) radionuclides (primarily actinide 1sotopes) fron high-level wastes generated in the commercial reprocessing 
of spent mu "onr resctor fuels. Decmue of the longlived and potentially

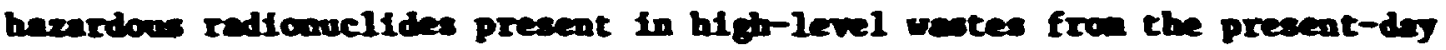
reprocesaing of nuclear fuels, prudenor dictates that these wastes be nanged for a allion years or longer in a numer ubereby they are reatrained

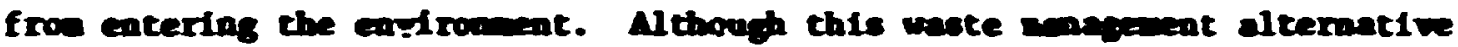
is a vible ase, it depend on predicting the stablitites of certatn geologil formetion ofth suffictent confidence to peritt their selection as atorase stes for the wastes.

Denoval of the long-lived (ectinides) redionoclides is a potential

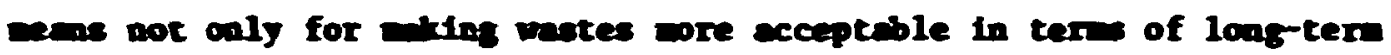
hasards, but also of alleviating storage requiremen.

Severai of the vaste angegent altematives beins studied by the USABC depend on sevarating and solidisying one streen containing fiesion products wth a accet tably low content of long-lived redionuclides ad producting a second sesipure, concentrated strem containing the long-lived radiconoclides. 1

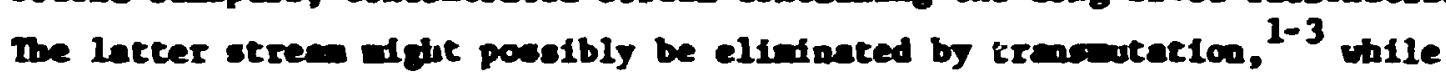
:he actinide-depleted, solidified fieston product stres aght be disposed of in reological fornaticas reliably predicted to be atable for tbousads of rears. [While there is considerable confidence in predicted stabilities of geological formations for thousends of years, there is leas confidence in such predictions for the pertod of a Allion years or wre required for senaged storage of fission products contalning the long-lived (actinide) radionuclides.!

The present study provides a part of the necessary terhnological basis for eveluating the waste managenent alternatives currently under atudy by the USARC. Inteialy, the eaphasis will be directed primarily at the wastes fron the reprocessing of LWR fuel because this is the oaly reactor fuel expected to be proceseed comercially durin;, the next decade. However, some attention will be given to LFBR and GTGR fuels, during the developwent of reproceseing concepts, to ake certain that whods for reprocesoing thise fuels are compatibie with processes for removing the long-11ved radionuclides. 
Spent LiR fuels contain esveral very loag-lived radionuclides - both actiaides an fission products - wich are discharged to wastes in conventional reprocessing. The actinides are the anjor contributors to the potential long-tern hazard, representing greater chan 992 of that for 1000-year-decayed waste. 2 The actinides of concern are uranim, neptuniu, plutcain, crictin, and curiu. The long-lived fission products of concern are ${ }^{99} \mathrm{TC},{ }^{93} \mathrm{Zr}-93 \mathrm{mb},{ }^{135} \mathrm{cs}$, and ${ }^{12}$ I. Removal of the actinides and ${ }^{129}$ I tu the resiced hegree would reduce the potential hazard posed by canned high-level waste after 1000 years to values comarable to those of naturally occurting uramion ainerals. 2,4

Comercial reprocessing of spent LWR fuel is carried out for the purpose of recover:ng the econonic values in the fuel. Uraniu and plutonim recoveries of up to 99.52 are attalined in convent lonal reprocessing. In sone iases, 90 to 952 of the nepiunit has been rtcovered for spectial uses, although it has no fissile vaive in comercial industry. The high-level waste ioes not contain all of the unrecovered uraniu, plutiniu, and neptinila. Significant anounts are also fund in interwediate- or low level wastes such as those ganerated in sacondary purffication cycles and in wastes accumlated from the purffication of sfent solvents. Sometimes these are concentrated and conbined with the is igh-level wastes. Anericius and curiu are not nornally recovered and thus are present in the high-level waste. The wolatile fission products, which include lodine, tritin, and the rare gases, are removed during reprocessing and are managed ds separate vastes.

Our Initial studies on the partitioning of high-level wastes showed the progian needed to be greatly expanded in scope. Secondaiy processing of the wastes fron conventional reprocessing is not the nost efficient way to accompl ish the desired levels of actinide removal. In addition to secondary processing of the high-level waste, the progran should also include inproved whods of reprocessing spent fuels. Significant advantages are possible by odifications of present-day reprocessing methods. P1rat, losses of fissile and ferttle values tc the high-level waste can be reduced; in addition, neptunium can be resoved by the Purex process, which 
is already exployed in the reprocessing plant. Second, there are potential wethods to elininate or recycla the niscellaneous low and internediatelevel wastes generated in the reprocessing plant which also contain ionglived radionuclides (primarily actinides). These dscellaseous actinidebearirg waster presently require relatively large-area sires fas disposal or storage. We have therefore expanded the original concept to include both iproved wethods for spent fuel reprocessing and secondary processing of the high-level waste.

Prelifinary calculations indicate that the potential loog-ten vaste hazard level achieved by remoling 99.97 of the urenion, aericiu, curiun, and ${ }^{129}$ I, 99.992 of the plutonion, and 952 of the neptuniu fron LWR fuels that utilize plutoniun recycie and have been irradiated to $33,000 \mathrm{md} /$ aetric ton is comarable to that from naturally occurring uraniu deposits. This werns that the total losses in all wastes (high-, internediate, and low level) wust not exceed 0.012 of the plutoniu, 0.12 of the urmiun, amenciun, curiun, or lodine, and $5 z$ of the neptuaiun. Attaining these recoveries of actinides will require that the recoveries of uraniun, neptuniun, and plutoniu be substantially increased over those achieved in conventional reprocessiag; in addition, anericiu and curiun will have to be renoved from the high-level waste. Considerable improvenents and advances in process wethods and technology will be required to attain the desireci actinide resoval. It mist also be renembered that any waste strean wose composition exceeds the maxim permissible concentrations for unrestricted release to the environment ( $10 \mathrm{CPR} \mathrm{20*}$ ) must be recycled to some appropriate step in the processing or combined with the high-level waste for disposal. irocesses employed to effect the necessary resovals of the long-lived constituents wust not utilize chenical reagents that greatly tncrease the voluwe of the solidified high-level waste.

retermination of the cechnical and economical feasibility of significantly reducing the potential iong-term hazards and storage requirements of comercial vastes is a mafor undertaking. It appears that the program

*Title 10 Energy, Code of Federal Regulations, Part 20. 
required is of the sace order of agnitude as the original progray to develof today's comezcial reprocessing methods. Ultinately, it will be necessary to operate a full-activity-level pilot plant (or desonstration plant) that satisfactorily treats all waste streans from a nuclear fuel seprocessing facility to confin the feasibility of separating the longlived radionuclides, demstrate the required operatioual and recycle techniques, and provide operating and capital cost data. This feasibility study can be divided into eight problen areas, wich are listed below in the order in wich the work should proceed; hovever, work in the different casks will often be carried out concurrently; and thus provide mutually beseficial inforation that will help to regulate and to deternine the progran details.

(1) Deternine the benefits of rewoving long-1ived radionuclides and, from this, infer the amounts to be rewoved.

(2) Develop an overall process concept that is conpatible with nuclear fuel reprocessing ethods and with ultimate disposal wethods for the wastes.

(3) Devise flowsheets that w11 accomplish the required removals hut wil not generate low or internediate-level wastes of potential long-tern hazard or greatly increase the volume of high-leve! waste. In such flowsheets, the exit streans would either weet the linits as defined by 10 CPR 20 , be combined directly with the high-level waste, or be recycled to the process.

(4) Dewonstrate each process of the overall flowsheet in laboratory-scale tests with synthetic feed.

(5) Carry out sall-scase hot-cell tests and demonstrate, at full activity liveis, the eteps of those processes that way be affected by irradiation.

(6) Perform engineering-scale investigations of new equipment or process concepts which require scale-up irformation. The purposes of this task are to examine the overall problem of 
waste partitioniug plant design and to reiate any individual problees in waste partitioning to the overall concept. Such investigations will provide design information for a "hot" pilot plant. This work is necessary in order to find and eliminate any equipment- or process-related difícul;ies that were not predicted on the basis of smalle:-srzle development work.

(7) Operate 2 full-activity-level pilot plant or dewonstration plant.

(8) Cn a technical and econonic basis, evaluate the entire ccncept for reducing the long-ter: hazard of wastes. This task will remain active throughout the duration of the progr=a. Judgents should be ade at each stage of the program t's determine whether problems arise that ake the concept infeasible. If the program proceeds through a full-activity demonstration, it will be necessary te prepare a final summary report dealing with all technical and economical aspects of the dewonstration concept.

A previous study ${ }^{3}$ of waste parcitioning included actinide removal from high-level waste and a general survey or possible methods for removing the actinides from fission products. Some of the main conclusions reached in that study were:

(1) The separation faccors for removil of actinides from highlevel waste can ralye from as $10, \pi$ as 10 to as much as $10^{6}$ to $10^{8}$, depending on the assumpticis and conditions of the spacific case. Most likely, they will be somewhere ir. the alddle of the range, probably between 100 and 16,000 .

(2) Adequate basic separations technology exists for developing separations processes which give separation factors of up to $10^{4}$, but it has not been applied to the particular problem of waste partietoning. 
(3) Solvent extraction and ion exchange processes hold the best promise of achieving the required separation factors.

(4) Solids present in liquid high-levei radioactive waste will complicate separations p;oces; development.

Ackriouledgents. The authors express their sincere appreciation to R. G. Wyer for technical advice throughout the course of this study and for edf.torial suggestions during the preparation of this report. Epecial think: are also due Martha G. Stewart for editing and to Jane Posey for typing this report. Significant portions of the experiental work reported in this study were capably performed by R. L. Hickey and D. L. Davis.

\section{BENEFITS OF RENUVIMG LONG-LIVED RADIOISOTOPE HAZARDS FROY HIGH-LEVEI. WASTES}

If th were possible th divid: wastes into a series of fractions strictly according to the half-lives of the radioactive colponents, the various waste fractions could then be released to the environnent one by one after suitable storage times. Thus, the fraction contanning only stable isotopes could be released imediately, the fraction con:aining isotopes with very short lives could be released after only a few years, and so on. On first consideration, this seem to be a particularly attractive concept for managing high-level waste from comercial reprocessing of nuclear fuel, since there are only a few fission products and actinide elements that have very long 11 ves. About 60 wt $z$ of the fission products will decay essentially to stable daughters in 100 years. After 1000 years, the only radioactive hazards remaining will stem from a few fission products (e.g., ${ }^{129} \mathrm{I},{ }^{93} \mathrm{Zr},{ }^{99} \mathrm{TC}$, and several others of 1 esser importance) and the actinides.

The difficulty with this approach to waste management is that lurge separwion factors arc requiced. Long-1tved footopes remaining in the fractions of stable (or short-11ved) isotopes cannot exceed the maximum permissible levels for uncontrolled release (as stipulated in 10 CRR 20). This requires decontamination factors (DFa) up to $10^{11}$ for release at 10 years, up to $10^{10}$ for release at 100 years, and up to $10^{7}$ for release at 
1000 years. All of these factors are greatly beyond the range of presentday technology, and it seems highly improbable that such seperations can be attained on a practical basis. However, as has already been intimated, advantages may be realized by separations which, although of somewhat poorer quality, wa be technically feasible.

In our inizial attemt to investigate this possibilfty, it was assuned that 99.97 of the iodine (which, of course, includes 99.97 of the iso:ope 129 I) would be removed in head-end processing and thus would not report to the high-level waste, and that resoval of actinides from the high-level vaste should be sufficient to decrease their hazard value at 1000 years to a hazard calparable to that of the long-lived fission products. With these actinide rewovals, the resultant hiph-leve: waste at 1000 years would have a hazard comparable with that of naturally existing ore bodies (onetwentieth of the hazard from high-grade pitchblende and 4,50 times the hazard from uraniun ores in the western United States). If it becoses necessary or desirable to decrease the hazard even further, significant anounts of the long-lived fission products, as well as additional anourts of the ar.cinides, will have to be rewoved. For the initial investigation, we will ccnsijer rewoving the actinides to only moderately low levels (1.e., to lavels posing hazards comarable to the hazards from long-lived fission products). The most demanding removals are required for $L W R$ reactor fuel with plutonium recycle. For fuel irradiated to 33,000 MHdmetric ton, these removals amount to $99.9 \%$ of the uranium, $95 \%$ of the neptunium, $99.99 \%$ of the plutonium, and $99.9 \%$ of the americium-curium.

Radioactive wastes from present-day reprocessing of nuclear fuel will remain hazaritous for over a million years; however, removing the long-lived radioisotopes as described above will greatly decrease the hazard for times beyond 1006 years. The actinide-depleted, solidified fission products might be safely disposed of in geological formations reliably predicted to be stable for thousands of years. The recovered actinides might be eliminated by transmutation. 
3. CalcUlation OF THE REQUiREd aCtiNIDE REMVVAL

Calculations were carried out to determine the degree of actinide rewoval, together with rewoval of 99.97 of the lodine, that would be required from spent fuels to reduce the actinides to levels where their contribution to the hazard index ${ }^{*}$ of 1000 -year-decayed waste would be comprable to that of the reasining long-lived fission products. When tr.e actinides and ${ }^{129} I$ have been reduced to this extent, the hazard index of i:igh-level waste after 1000 years of deray will be in the range of calculated hazard index values for uranive ninerals; it will be onily about 52 of the value for pitchblende. The calculations showed that wastes from the refrocessing of uraniumplutoniu fuels vill require resoval of uranius, neptuniun, plutoniun, anericin, and curius wastes fron thoriuuraniun fuels will also require removal of thcriun and procactinius.

It is likely that the calculations of actinide removal presented here will eventually have to take into account the possibility of breach of containment and be extended to include an environmental pathway analysis in which the physical and chemical forms of the wastes and radionuclide content are evaluated with respect. to potential modes for solubilization and to mechanisms of transport in environmental media. However, the calculations based on comparative hazard index values are entirely satisfactory for the initial worix on the evaluation of the technical feasibility of actinide removal.

\subsection{Basis of Calculations}

The detalls of the calculational method and the bas1s on which the calculations of the required actinide removals were made have been reported

\footnotetext{
*The hazard index is defined as the volume of water required to dilute: unit volume of a radionuclide mixture to the levels defined in tire Code of Federal Regulations (10 CFR, Part 20) as the maximum permissijle corcentri son for unrestricted use of water. The hazard index provideg only an approximate comparison of radiological risks since it does not allow for accumulation or reconcentration of a nuclide in environmental media, or for the total impact of a number of nuclides. Por limited comparisons, it is an acceptable alternative to dose calculations if used with caution.
} 
previously. ${ }^{2}$ Therefore, only the basis of the calculations need be presented here to provide an understanding of the percentage removal requirewents of the actinides from high-level wastes.

The effect of the degree if remval of actinides on the radiological toxicity was estiaried by calculating the hazard index value as a function of tine for the aixture of fission products and actinides that remained in the high-level vastes after assuned percentages of inftial artinid: removal. The bases on which these calculations were ade were as follows:

(1) The total quantities of actinides not recovered in the processing of 1 eetric ton of spent LI, UTLE, and HTG fols were aouned to be prevent it 2, 3, axi $6 \mathrm{ft}^{3}$, respectively, of solidified hish-level fission product waste.

(2) All of the rare gases, 1002 of the trition, and 99.92 of the lodine were assuned to be remved as separate wastes In the fuel reprocessing and heace vere not present in the high-level fraction. The total quatities of all other fisaton products were asesed to be present in this fraction. Wone of the activation pmoucts produced in the fuel cladding was assumed to report to the high-level waste.

(3) Puels fron a 1000-iw(e) LWR of the pressurtized water type (PWR), a 1100-Mid(e) LAFBR of the General Eiectric Follow On (GEPO) design, and a 1160-raw(e) refereace deeign ITGR were used as the representactive classes of fuls in a commetal industry. Two clases we considared for the LWR: PWR-U, In which there is no recycle of the plutoniun: and Pin-Pu, In which the plutontur to recycled. It was aesued that waste fros pirk-Pu was bleaded (one-third PinPu - two-th1rde PrR-U). 
(4) The average exposures of the LWR, LYFBR, and ITGR fuels were assuned to be $33,000,41,200$, and $94,300 \mathrm{mid} /$ metric ton, respectively. The fission product and actinide contents of the speat fuels were calculaced by use of the ORIGers' code.

(5) Radiation control guide (RCG) values were not listed for all of the nuclides in 10 CFR 20. Therefore, the BCG values calculated by Laveme ${ }^{6}$ were used for any unlisted nuclides. Appendix $A$ of this report gives the hazard index values that were used to calculate the desree of

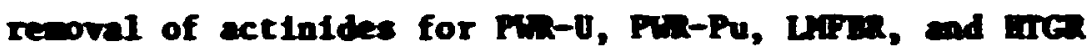
fuels.

(6) Hazard Index values of $1 \times 10^{8}$ and $1 \times 10^{5}$ vere uned for pitchblende and domestic ores, respectively. These values reflect the range of ureailo concentration found in ecoavefic ore deposits (see Appeadix B). On a hazard index basis, pitchbleade represents the upper linft of coxicity of redfouctive aberals.

\subsection{Degree of Actinide Rewoval Required}

Plgure 1 shows the effect of the removel of actinidas from high-lewel wastes. The hatard index of high-level waste searated by conventional reprocaselas of spent fuel from a typical un (no plutoatun is recycled) is comared with that of the seme wate after additional removel of actinidae by secondary treatecent. It was asound that 99.91 of lodine

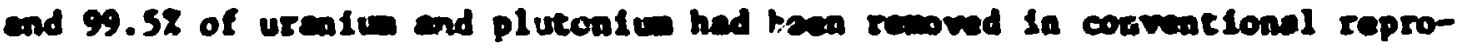
ceesing. wherees 99.558 of the plutontiv, 99.92 of the ureation, earicion, curiun, and lodine, an $95 x$ of the neptuate ind been renoved in combined

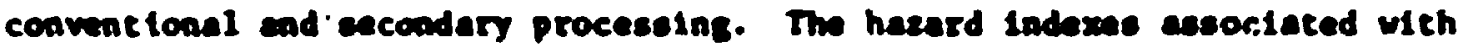

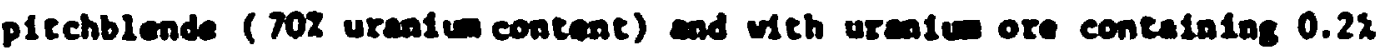
urention (high-grede tometic ore that occurs in the celorcdo Plateauj are included for reference purposen. As seen, the haserd ladex of vasces 
Cnme owe 74-1010sn1

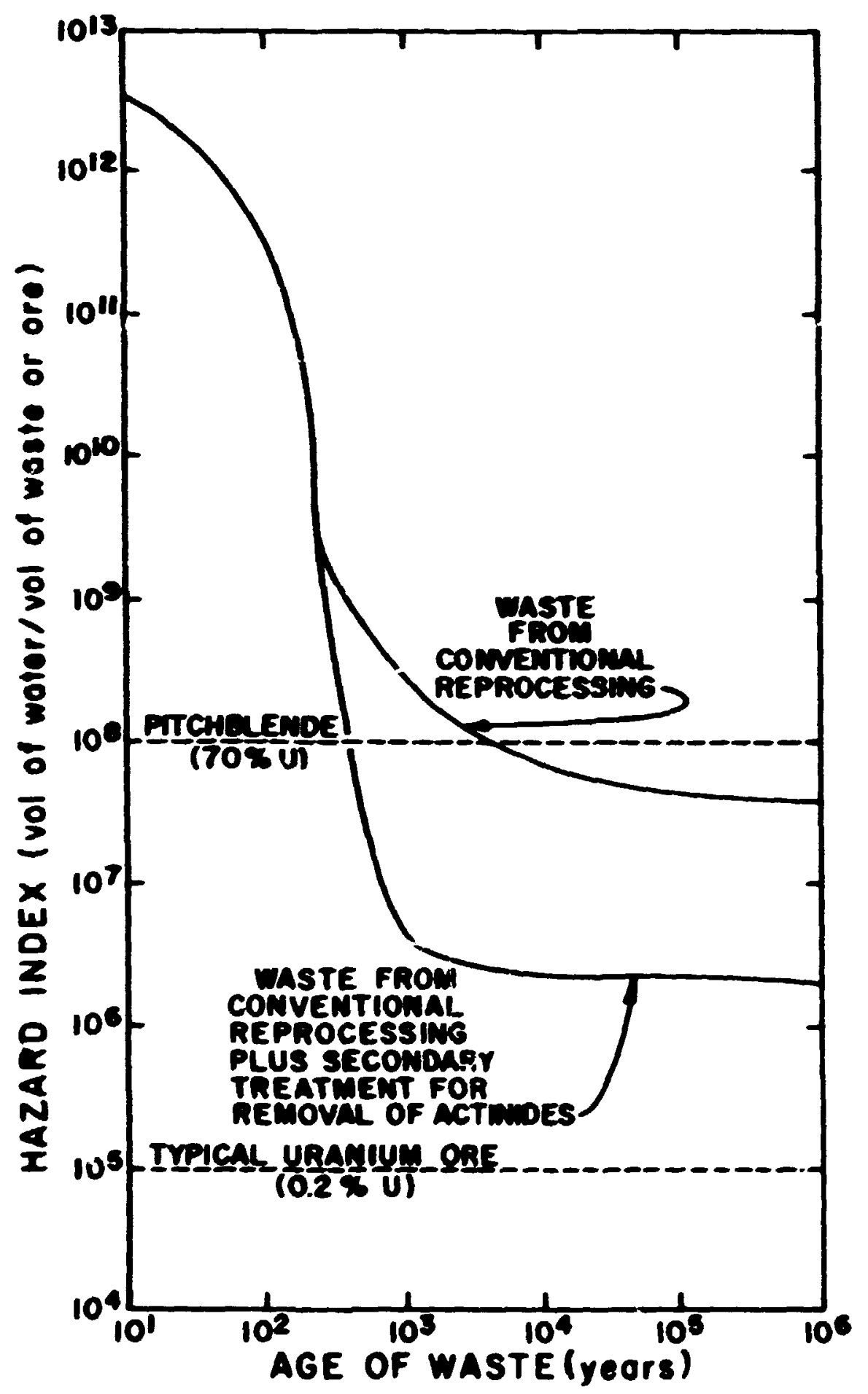

P1g. 1. Effect of age and wethod of treatent on the hazard index of high-level wastes fron LWR. 
generated by conventiunal reprocessing decreases rapidly over the first 1000 years (due minly to decay of ${ }^{90} \mathrm{Sr}$ and ${ }^{137} \mathrm{C}_{5}$ ) but reanins almost as great as pitchblende for worn than a alliton years. However, the harard index for waste produced by secondary treatment falls well within the range of naturally sccurring radioactive materials after only about 1000 years, a tile span for which the effects of geologic, climatic, and other natural phenomena can be reliably predicted.

One wethod for disposing of the separated actinides and ${ }^{129} \mathrm{I}$ would be to recjcle the with fresh fuel to power reactors. Previous calculations 2 show that even after sustaived recycle of these anterfals (which would tend to build up the levels of the actinides), the hazard index of the waste would still lie wibin the range of aturally occurring radioactive anerals aithough it is 20 to 307 higher than without recycle.

Table 1 gives the percentage rewoval of each actinide elenent for different reactor fuels that would be requited to reduce the hazard index of wastes after 1000 years of storage to about $5 z$ of pitchblende. Eacin fuel type requires removal of uranion, plutoniun, neptuniun, and antricu and curiun; in addition, HTGR fuel requires rewoval of thoriun and protactiniu. If it is assuned that conventional reprocessing renowed 99.52 of the uraniun and plutoniue fron all fuel types, plus 99.52 of the choriu from HTGR fuel, the secondaxy treatment of waste to achieve the overall removal of actinides shown in Table 1 reduces the hazard Index of 1000year-old wastes from conventional reprocessing by factors of $60,400,260$, and 270 for PWR-U, PWR-Pu, LMPBR, and HTGR fuels, respectively.

Evaluation of the technical feasibili:; of actinide renoval proceases for LWR fuels will be based on the removal requireo for PiR-Pu fuel, which are equal to or greater then rewovels required for Pis-U fuals. To attain the required rewoval of actinides from apent pus-pu fuele, atnim additional removal factors from high-level waste of $5,20,50,1000$, and 1000 are needed for uraniun, neptuniun, plutoniun, americtu, and curlu.

Figure 2 shows the relative contribution of individual ectinides and fission products in PWR-Pu waste af ter rewovel of 99.997 of the plutontu, 
Table 1. Percentage reovels from spent fuels required to reduce the hazard index of esed nastes to approxdmately 52 of that of pitchblende

\begin{tabular}{|c|c|c|c|c|}
\hline setinide & Fin-ס & rin-Pis & Luter & Brea \\
\hline $\mathbf{T h}$ & & & & 95.5 \\
\hline$P=$ & & & & 95.0 \\
\hline $\mathbf{v}$ & 99.9 & 99.9 & 99.9 & 99.99 \\
\hline P & 95.0 & 95.0 & 70.0 & 95.0 \\
\hline Po & 99.95 & 99.99 & 99.99 & 99.9 \\
\hline $26 \pi$ & 99.9 & 99.9 & 99.9 & 95.0 \\
\hline
\end{tabular}

Hacrel contatatng 708 uraite.

99.92 wf the urmin, cerictin, curlon, and lodine, and 952 of the nep"

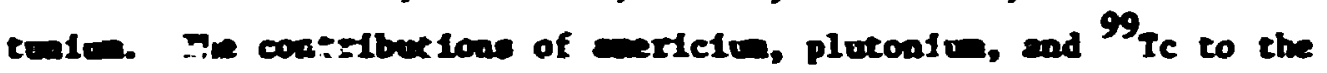
hasurd Intex of the Min-Pu wate at 1000 years are about equal, sad thcee rallonuclides constitute about 802 of the calculated hazard index of the wate. The relative contributions of actinides and long-1ived

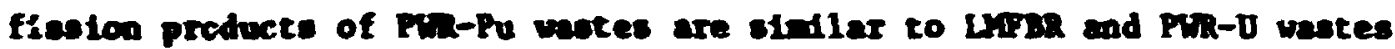
hovies the actinide resovals thown in Table 1 (see Appendixes C aud D). On a calculated hazard ladex besis, further removal of actinides frow Thim-Pe waste would not be varrented unlese one also rewoved the ${ }^{99}$ TC.

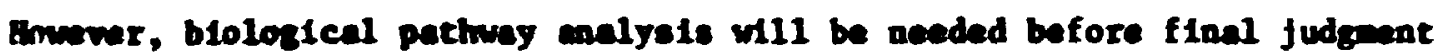
cen be ande concerning the destrability of additlonal actinide removal wthout a comensurate renovel of lops-11wed fission products. 
ORNL Ong $74-7906$

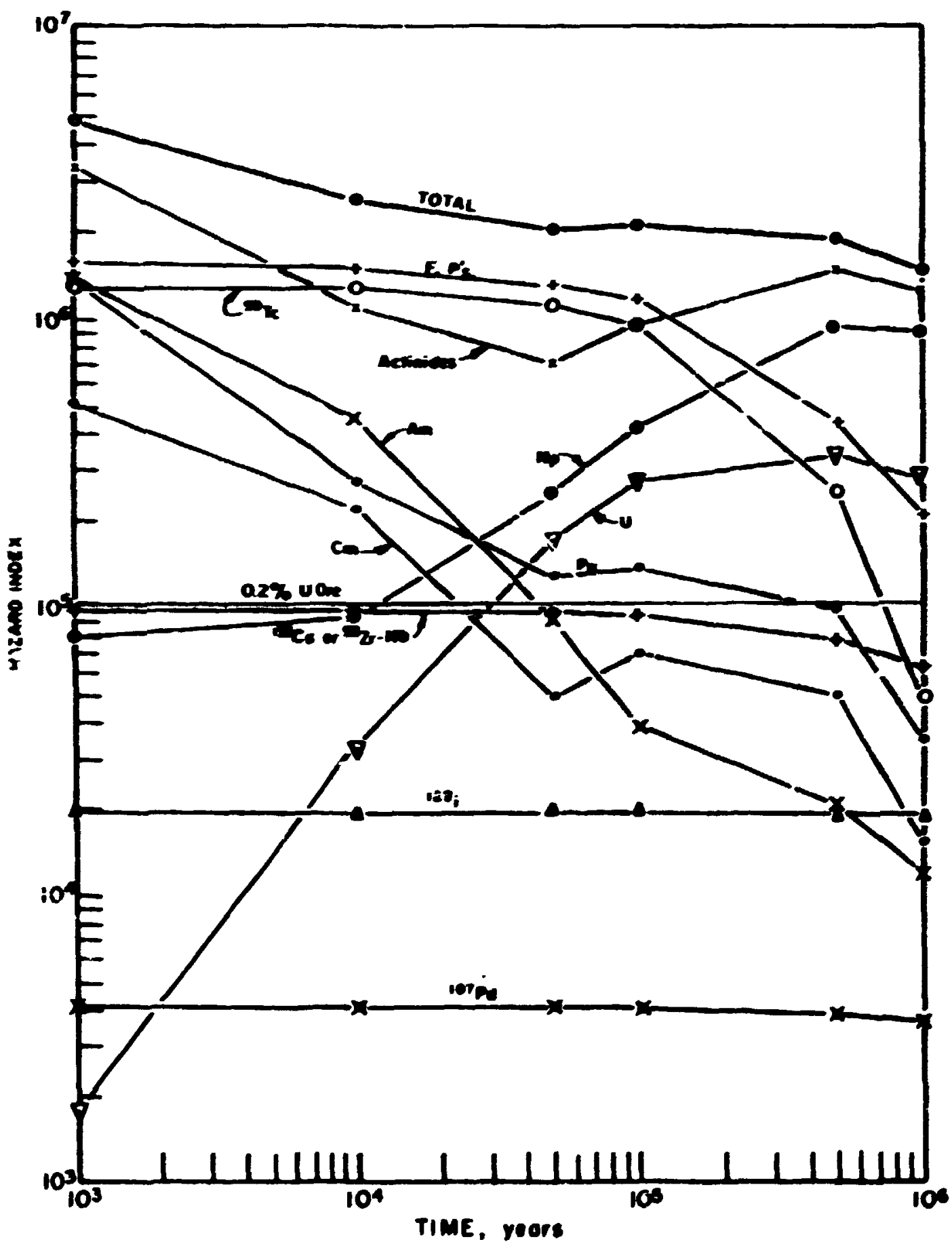

718. 2. High-level wate from the reproceselag of opent Pu recycle Un fuel 1rradiated to a burnup of 33,000 mid/toa.

Aseund resovale: Pe 95x;

$1231, Y, A, C$, C9.92;

Pu, 99.99\%. 


\section{CJRREAT PROCESSES FOR RECOVERIMG ACTINIDES}

The recovery processes that are reviewed here are aninly those which have been utilized on the largest scale of plant operations or that have the greatest potential for recycle of process wastes and chenicals. The extensive literature relative to separation of actinides fron fission products uas surveyed in a previous study. ${ }^{3}$ In cases uthere no clear potential adventages could be -stablished for processes not yet sufficieatly developed for large-scale apf-ication, it appeared that increasing the recovery of actioides to the desired level by ifprovenents and eodifications to processes currently aployed in fuel reprocessing and in transplutonium-element production prostas was the wost desirable approach. Toese processes vere developed originally to provide recovery of actinides for their econonte value; therefore, relatively littie effort uas ode durtine their developwent to achieve a ere quatitative recowery by additioal recovery cycles and by optional recycle of raste streas. Processes presently wed in comercial fuel reprocessing plants ar gite uranto ad plutonfun recoveries of up to 99.52. Troe 90 to 992 of the neptunion and anciciu-curion are normally recovered in special processing which is carried out to recover actinfdes for research purposes and certain specific wes.

\subsection{Processes for Uranim, leptuniun, and Plutonilu Recovery}

Uraniun, neptinlum, and plutoniu are normally recovered fron nitric acid solutions of actinides and fission products or of spent fuels by the Purex process. In this process the three actinides are extracted into tributyl phosphate (TBP), leaving the fission products in the aqueous phase. Separation of the three act aides from each other after coextraction by TBP is then accomplished by partitioning is subsequent solvent extraction cycles or in anion exchange cycles. At present, it does not appear that there is any obvious advantage in considering any extractant other than TBP for the primary recovery of urenium, neptunium, and plutonium from solutions of fission products. Although various other colvents have bean the subject of 
considerable research during the past 25 years, none has proved to be superior to TBP for recovering uranium, neptunium, and plutonium from solutions of actinides and fission products. 7

\subsubsection{Uraniue and plutoniun}

The only comercial operating experience with the recovery of uranium and plutoniu in large-scale processing of LWR fuels has been at the West Valley Facility of Nuclear fuel Services, Inc. (NFS), which uses the Purex process. Two new reprocessing plants, General Electric's Midwest Fuel Recovery Plant (MFRP) at Horris, Illinois, and th: Allied-General Barnuell Nuclear Fuel Plant (BxPP) at Barnuell, South Carolina, were also designed to use a Purex flowsheet for the primary rersvery of iraniun and plutonium. The Purex process flowstret used as a design basis for MERP includes the routine recevery of neptunim and plutonim. At the BFS plant and at XJTP, the Purex proceas nowsheet calls for the discharge of aeptunin to the aquesus, high-level fission product waste strean. (If desired, the nepcuniu-bearing yaste wy later be recovered by batch processing isi:g the Purex process.) Iecently, it has been ano:nced that the future operation of the MIRP is uncertain, primarily because of the inoperability of ceztain equipment and processes related to conversion of the purified uraniun to $\mathrm{UP}_{6}$.

Figure 3 shows a scheaatic Purex flowheet which typifies that used by the NTS plant. The MFS plant is presently shut down for modfications and additions wich will increase its capactity and waste handling capability. Uraniu and plutonim reccueries of about $98.5 \%$ were achleved in the NFS plant during average operation. The high-ievel aqueous waste generated in this plant contains greater than 99.92 of the nonvolatile fission products as well as a large fraction of the unrecovered uranium and plutonium. In addition, it contains essentially all of the neptuntu and traneplutonium elenents. Aqueous wastes generated in the uraniug and plutonium purification cycles that utilize TBP extraction are concentrated by evaporation, and the nitric acid values are recovered (see $\mathrm{Fig}_{\mathrm{g}}$ 4). The concentrater, purffication-cycle wastes are cowbined with the sintlazly concentrated 
ORNL DWG. 74-2002RI

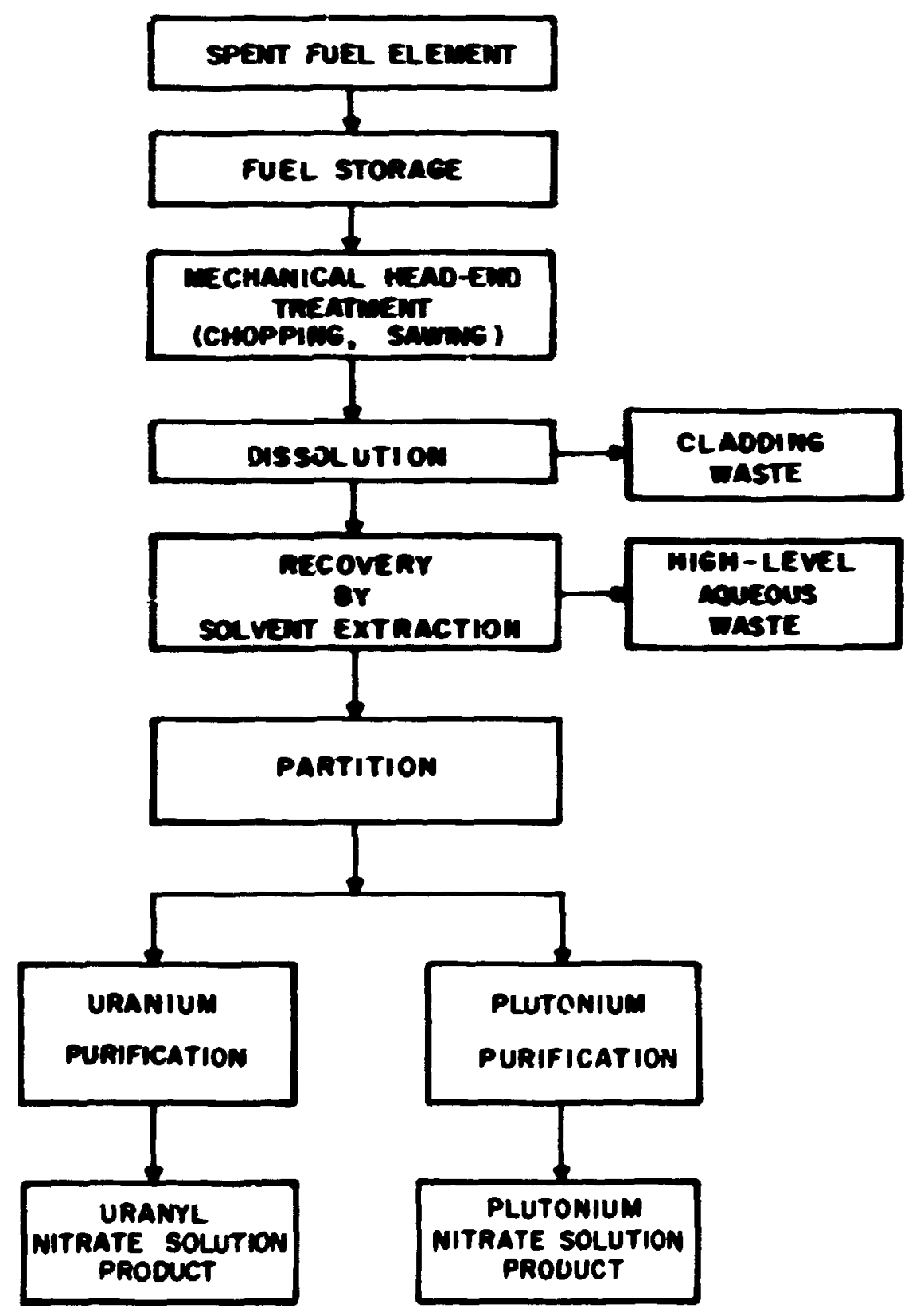

F1g. 3. Outline of conventional processing us-.ng a Purex process. 
OANL On ra.roos

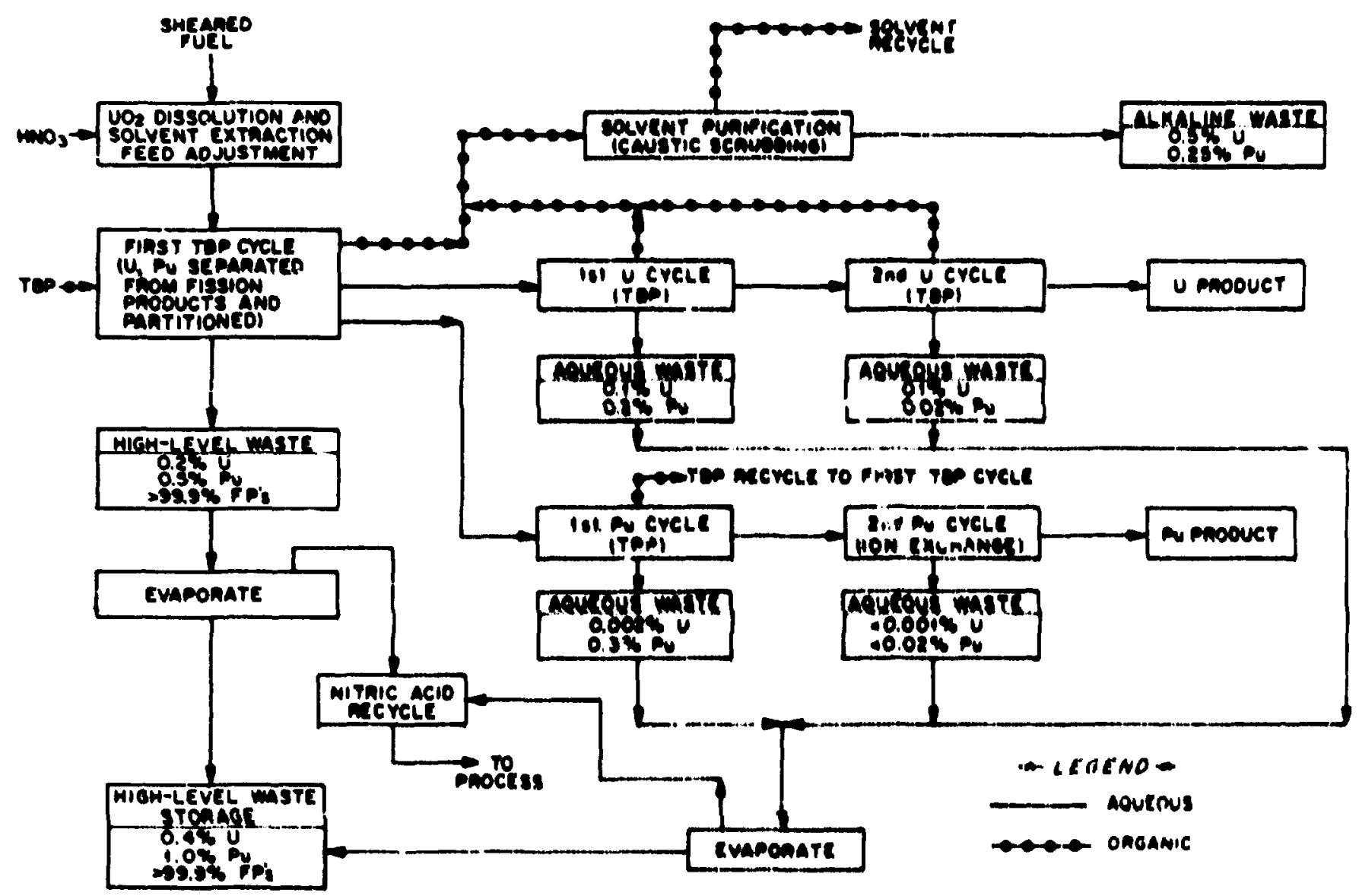

F18. 4. Recovery of urantum and plutonlum by the Purex procasa in the Nuclear Fuel services planc. (Uranlum and plutoulum percuntagen ara typical values.) 
high-level waste fron the first-cycle solvent eatraction. Recycling the concentrated aqueous wastes from the uranium and plutonium purification cycles to the feed to the first-cycle solvent extractinn would avoid the losses from these cy:les. With recycle, the uraniug and plutonium losses to the concentrated hig:l-level waste would be expected to be about 0.27 and 0.57 , respectively, rather than the corresponding 0.47 and 17 expected with no recycle. The losses 1 isced for the waste streams shown in Fig. 4 are based upon the plant input and were estimated from processing sampaign experience in which Yankee Atomic fuel having irradiation exposures of 8500 to $16,500 \mathrm{Md} /$ metric ton was processed. 8 Uranium and plutonium losses to the alkaline waste from solvent purification by caustic scrubbing were 0.52 and 0.32 , respectively. Processes fcr removing the actinides from the alkaline wastes or new methods for purffication of the solvent will have to de developed if the overall recoveries from spent fuels shown in Table 1 are to be achieved. Fue: exposures in LWRs are expected to be about 33,000 Mid/metric toin, and even greater losses to the alkaline waste may possibly occur when solvent purffication is effected by caustic scrubbing.

During the operational period of the NFS plant, there was no economic incentive to recov.s the nepcunfum from comercial fuels. Therefore, flowsheet conditions were chosen so that neptunfum was rejected to the highlevel wastes. About two-thirds was rejected directly in the first-cycle solvent extraction, abrut one-tiif $r$ in the two plutonium purfification cycles, and aic:: i? in the two uranium purification cycles.

\subsubsection{Neptunium}

Varfous nep:unfum recovery methods based on solvent extraction from nitric actd soiutions of nuclear fuel have been developed; however, only those merhods in which the Purex process plays the major role have found applicability in large-scale processing. ${ }^{9}$ Considerable experience exists for recovering neptunium via the Purex process in programs iaviving the production of ${ }^{238} \mathrm{Pu}$ at Hanford and at Savannah River. Generally, 90 to 99\% recovery of the neptuniun has been achieved, depending on the processing rate required. The lower recoveries were cbtainsd at high processing rates 
and were apparently caused by the slowness of the kinetic processes for neptunius valence ajjustment relative to the processing rate required in the production campaigns.

Two basically different approaches have been used for recovering neptunium by the Purex process:

(1) Coextraction of neptunium with uranium and plutonium in the first extraction cycle, and separatici from these othar elements in subsequent cycles.

(2) Rejection of neptuniw as $\mathrm{Np}(\mathrm{V})$ to the high-level aqueous waste in the first extraction cycle, and recovery from the waste ty ion exchange or solvent extraction methods.

The first approach is clearly the wost advantageous for use in a Purex plant where comercial fuels are processed. The radiation damage is reduced because most of the fission products come in contact with solvent only in the initial extraction colum, fewer process steps are required, and less additional equipwent is needed. Therefore, only this approach is discussed here.

Coextraction of uranium, neptunium, and plutonium is effected in the first cycle of the Purex process by adjusting the valence of the neptunium to $N_{p}$ (VI) by nitrous acid-catalyzed oxidation of $N p(V)$ with nitric acid. Neptunfum can then be separated from uranium and plutonium in subsequent Purex extraction cycles or by anion exchange cycles. When the three actinfdes are cuextracted, it appears that their separation in additional Purex extraction cycles (as is done at Hanford) is more advantageous than costripping followed by separation by anion exchange (as is planied at MFRP). Since these extra cycles of the solvent extraction are similax to the main Purey. cycle, recycle of waste sireams and prnac:s chemicals is simplified. A reducing agent is requited, regardless of whether the three actinides are partitioned by solvent extraction or by anion exchange. 
In the recciery and subsequent sepsration of uraniw, neptuniun, and plutoniu by Purex processing at Banford, the three actinides are coextracted as U(VI), Np(VI), and Pu(IV) fron 2 to $3 \underline{M} \mathrm{ENO}_{3}$ solutions; the plutoniun is then stripped fron the TBP by an aqueous ferrous sulfanate solution which reduces Pu(IV) to Pu(III), leaving the U(VI) and Ip(IV) in the organic phase. The uraniu and neptuniu are subsequentiy separated in the serond uranium purification cycle, where Ip(IV) is partitioned to the aqueous raffinate by keeping the organic phase highly saturated with uraniu. Some of the important variables in the recovery of neptuniun in the Hanford pulsed coextraction colun are:

(1) nitrous acid and nitric acid concentrations at all points along the colum profile,

(2) colun temerature,

(3) pulse frequency and aplitude,

(4) processing rate, and

(5) degree of uranium saturation of the orgentc phase.

\subsection{Processes for Anericiun and Curium Recovery}

Considerable experience exists relative to the recovery of anericiun and curium in connection with transplutoniw-pienent production programs at Oak Ridge National Laboratory and the Savannah River Laboratory. Typically, recoveries have been 90 to 99.7 from specially irradiated targets. The separation wethods have consiszed of combinations of solvent extraction, ion exchange, and precipitation steps.

Several differs processes have been utilized in the sequence of separations required for recovering the transplutonium elements. However, separation of the transplutonium elements from the chemically similar lanthanide elements has wst often been effected by the Tramex process, 10,11 which is based on extraction of the transplutonium elewents from concentrated LICl solutions. Of course, processing equiprent that comes into contact with such solutions, which are very corrosive, must be constructed of special and expensive materials; consequently, LiCl-based processes are 
not presentiy considered to be practical for renoving anericiu and curium from comercial high-level wastes. Thus, the only process that has been used to any great extent for the recovery of aberiction and curiun in mitigran mounts on a plant scale is unsuitable for improvenent and adaptation to the rewoval of these actinides from high-level wastes.

Two processes that have been developed as possible alternatives to the Tramex process appear to have the potential necessary for providing a high degree of resoval of anericiu and curiu from lanthanide fission products. One is a cation exchange chromatography (CEC) process; ${ }^{12-14}$ the other is a solvent extraction process, Talspeak * 15,16 However, neither of these processes has been denonstrated at radioactivity levels comarable to those encountered in the Tranex process. Also, each requires an actinide-lanthenide feed solution that is essentially free of the other fission products. A considerable amount of development work wll be needed to deteraine whether these processes are feasible for uee in recoverting anericiu and curiu fron high-level wastes and whether wethods for preparing suitable feed solutions for these processes can be worked out. If not, a wholly new approach aust be developed.

\subsubsection{Separation of arericiv and curiun from lanthanide fission products}

The avallable processes that appear to have the greatest potential for use in the separation of anericiu and curiun from the lantianide fission products are $\mathrm{CEC}^{12-14}$ and Talspeak. ${ }^{15,16}$ other methods currently exployed for trivalent actinide-lanthanide separations were judged to be unsultable primarily on the basis of the types and/or anounts of chenical reagents used in the processing.

Cation exchange chromatography (CEC). Processes based on CEC have been successfully applied to witigras separftions of anericium and curium from fission product lanthanides both at Hanford and at Savannah River. 12-14 Existing flowsheets for these processes require a feed that contains only

*Acronym for trivalent actinide-lanthanide separation by phosphorus reagent extraction from aqueous (k)omplexes. 
Anor sounts of other fission products snd inert aterials, other than sodiun. With this type of feed, resin colums cen be loaded to neartheoretical exchenge capacity without calusing breakthrough of setinides and lanthanides when solution with acidzities a high as 1 I are used. it Organic reducing agents, such as foralc actd, are iead to adjust the acidity of the solution by chenical zaction with the excass nitific acid. After the actinides and lanthanides have been sorbed on a loading colun. chromatogrephic separation is effected by band displecemant through a serfes of lor exchanfe coliuns with en elueat contalaing a chelating

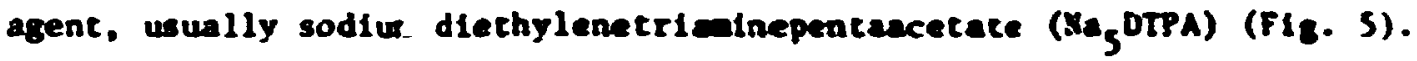
inc is employed as a bartier fon so that the developing bands remain "sharp" for the individual elesesto throughout the any bad displacement volues that are required for separation and purification. "End-cuting" of products is sifulified by effecting band displacenent through a sertes of successively saller-dianeter coluns. This resin configuration ainiaizes the losses due to end-cutting and, in turn, the quantity of aaterial that must be reworiked and recycled. Because of the large quantity of zlinc that is needed for providing the barrier lon, zinc will need to be recycled. Also, significant anounts of contaninated uaste resin will be produced because of wechanical, chenical, and radiation danage to the resin particles. Recycle of the ccaplexing agent, DTPA, would be desirable; however, an altemative is to convert it to a noncontaninated gascous chesical waste. Solutions to these recycle problews and to disposal of waste resin and DTPA will require further study of both a conceptual and an experimental nature.

The CEC process has been developed at Savannah RIver ${ }^{14}$ for a capacity of about 20 woles of rare earths and actinides, although not at ful] activity levels. This is about one rourth the capacity necessary for the americiu, curlus, and rare earths in 1 setric ton of LUR fuel.

Talspeak process. The Talspeak process is based on the preferential extraction of lanthanides from trivalent actinides by di (2-ethylhexy 1 )phosphoric acid (HDEHP) from a carboxylic acid solution contrining $\mathrm{Na}_{5}$ DTPA. 


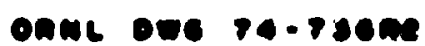

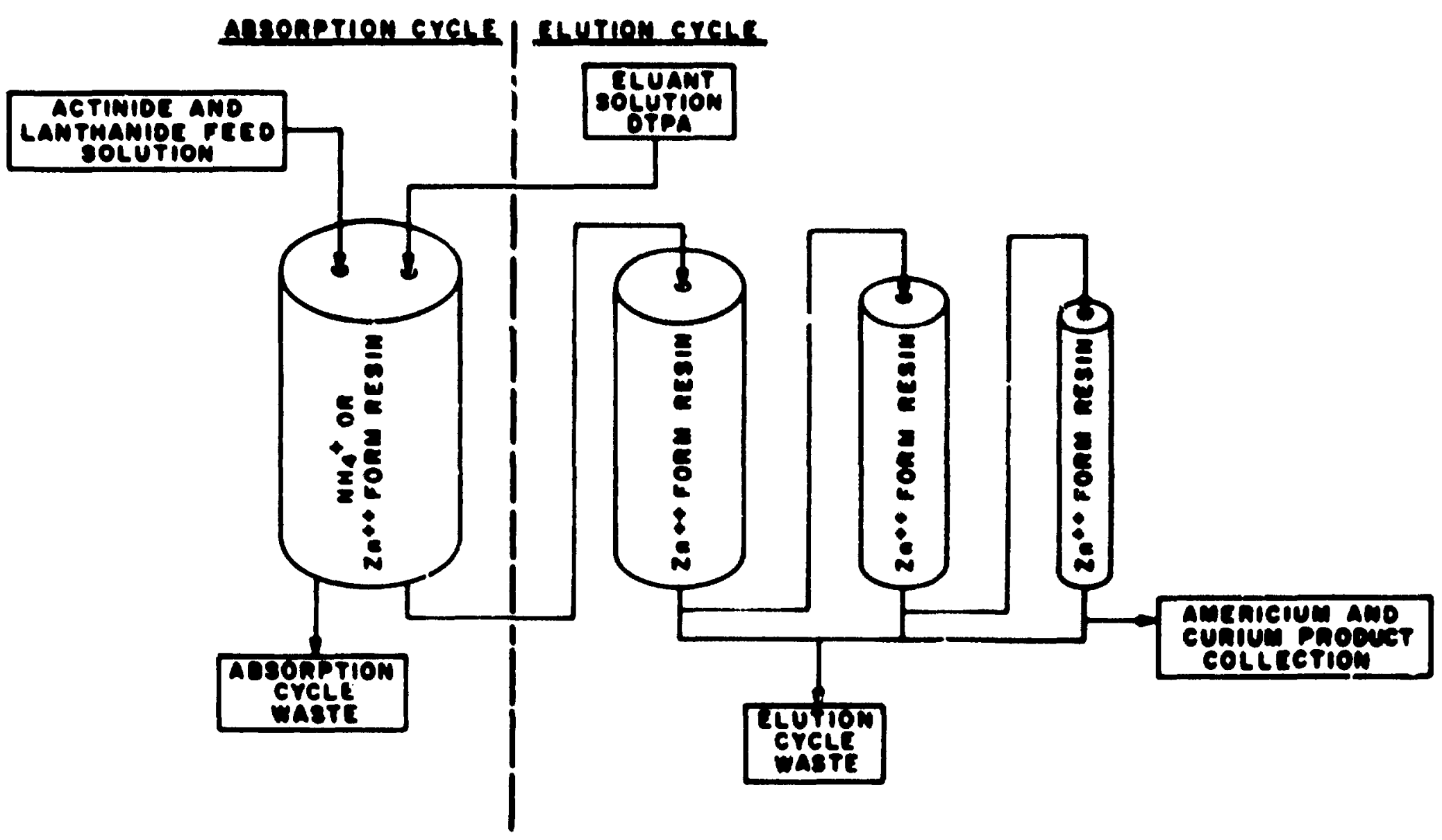

F18. S. Schemaitc flowsheet of catton axchanga chrowatonraphlc procesa for recovery of americlum and curlum. 
A conceptual flowheet for a Talspeak process is shown in Fig. 6. According to this flowheet, the lanthanides are separated from the actinides by extraction from a 1 피 lectc acid solution of these elements with 0.5 abdip in dilsopropylbenzene diluent and then scrubbing the organic phase with a colution costaining lectic acid and Me $\mathrm{DTPA}$. The pH of the squeous phase is antatied at 2.5 to 3.0 . The ancicium and curfiu an be recovered a oxalatea by prectpitation fron the aqueous phase or as a nitrate solution by an additioal cycle of solvent extraction with bDaip as the extractant. Extrections froe 1 트 colutions of a nuber of carboxylic actds (fornic, acetic, propionic, ad waloaic acids) have also been shown to be effective. 15,16 The choice of carborylic actd depends on the particular application.

The development of the Talopeak process has been confined, for the wost part, to tracer-level laboratory studies. Linited atudies have been carried out at Karlaruhe relative to removal of anericiu and curiue from waste solutions. 17 In view of this, considerable developwent work will be required to deternine whether the Talspeak process is feasible for use in the recovery of anericiun and curtim fron high-level wastes. Acceptable wethods would have to be developed for the preparation of a sultable lanthande-actinide feed for the process; In addition, an improvenent in the extraction kinetics would be desirable. The process chenicals, other than sodiun, are organics and have the potential for being elininated from the final calcined highlevel wastes by volatilization or combustion methods; however, acceptable disposel wethods would have to be developed. Improved wethods for purifying the HDEHP solvent used in the process are also needed. Comercially avallable HDEHP contalns oderate anounts of ipurit1es which are detrimental in the processing and wat be removed. A practical wethod for this furification is needed.

\subsubsection{Preparation of sultable trivalent actinlde-lanthanide feed solutions from h1 hi-level wastes}

As discussed previously, all processes presently used for separating trivalent actinides from lanthanides require feed solutions that are esnentially free of zertain fission products. These fission products would 
DNNL Dwg. No. C4.8378R2

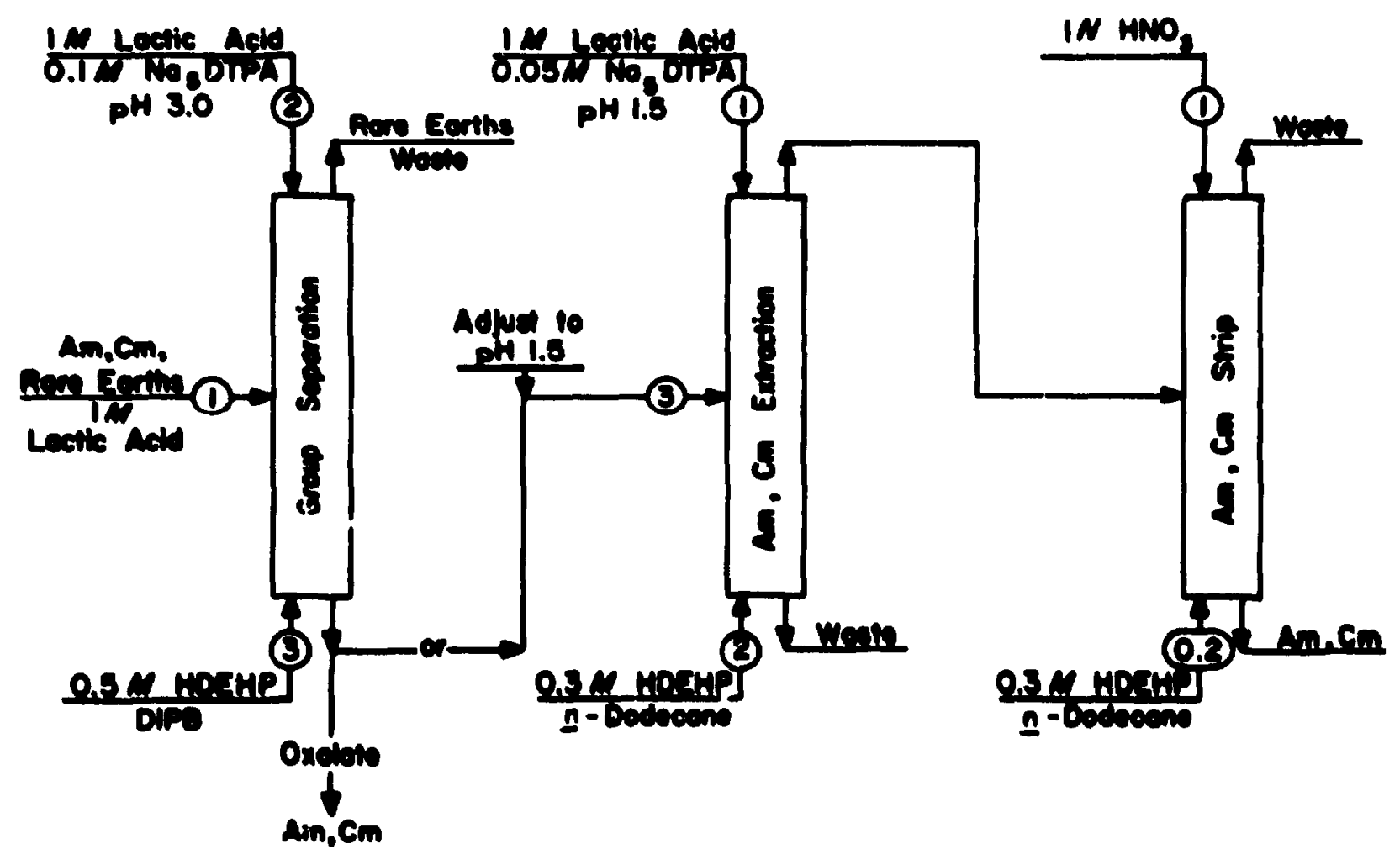

P18. 6. Conceptual flowhent for recovery of anoriclum and curlum by a ralepeak procses. 
precipitate vis hydrolysis in the lowacidity solutions esployed in the subsequent processing. Also, the pres-roe of phosphate ton in the highlevel vastes from Purex processing could cause actinides ad lanthenides tu precipitate at low acidities.

Feed solutions are generally prepared by removing the actinide-lanthande fraction from the ocher fission products or chenicals present fron the prevtous processing. Currently exployed athods of feed preparation have not been developed to a sufficient extent to give the recoveries required for anciciua and curiu from high-level waste. It is possible that the methods presently being uned in trmoplutoniurelement production prograw could be codified to give the required reconeries. Howeve, wost of these methods require large quantities of nonvolatile chentcals wich, because they cannot be recycled, vould increase tine final iviune of high-level fisstion product waste by prohibitive anounts. The methods that appear to have the greatest potential for preparing satisfactory feed solutions from high-level wastes are:

(1) TBP extraction of lanthenides and actinides from solutions salted by aluninu nitrat?,

(2) Ion exchange separation of the lanthanide-actinide fraction,

(3) specific extractants for trivalent actinides and lanthanides fron acidic solution, and

(4) rewoval of easily hydrolyzable fission-product elewents by solvent extraction (selective fission-product resoval). Perhaps some combination of these wethods way be superior to any one of then.

TPP extraction of lenthanides and actinides. The extraction of trivalent actinides and lanthanides by TBP fron fission product solutions salted with aluinu nitrate has been utilized in transplutonium-element progras. 11,18-20 This process is operated batchwise, with the actdicy betng adjusted between successive extractions. Since low-acidity solutions (0.1 to 0.35 M) are required, precipitation occurs if soc much acid is extracted by the TBP or is destroyed by radiolysis in the piscessing. 
Americiun and curiun recoveries of 95 to 992 are usually achieved by two batch extractions. To be useful in waste partitioning, this process would have to be modified to attain the desired recoveries and to allow the salting agent to be recycled. The low acidity required for extractability of the actinides and lanthanides in TaP presents difficult control problems relative to product losses by hydrolysis and precipitation reactions both in the extraction process and in preparetion of the squeou feed for the process.

A flowsheet for the recovery of greater than 99.52 of the lancharides and actinides by meanb of a continuous countercurrent extraction with ToP In axer-settlers has been dewonstrated at Savanash River, although not at full activity levels. 19 This flowsheet is also potentially aplicable to the separation of actinides plus heavy lanthanides fron the lighter lawthanides. As shown in Pig. 7, the first step in the process involves coextracting the lanthanides and trivalent actinides into acidified TBP, along with any other actinides and wot of the rutheniu and zirconion, from a feed solution highly salced with aluinu nitrate (2 $\underline{M})$. The trivalent actinides and lanthanides are then selectively stripped into dilute nitric acid, leaving zirconiun, rutheniun, and any actialdes at higher valence states [e.g., U(VI), Pu(IV)] in the spent solvent. Material balances for this flowheet were based on high-level wasts from the reprocessing of 1 wetric ton of Lip fuel irradiated to a burnup of $33.000 \mathrm{~m} /$ metric ton. It was assumed th.at 5000 liters of high-level waste was concentrated into a highly salted feed volune of 20m liters. This assuption may be optinistic. The amount of nitrate salts needed for processing th!s volume of waste is about 2 metric tons - a proh bitively large quantity. The flowsheet given here (FIB. 7) typifies the disadvantage of separations based on high metal ;alt strength, regardless of whether they are accowplfahed by solvent extraction or ion exchange.

The feed solution to this process 18 prepared by steam-stripping the high-activity waste from a Purex plant to reduce the nitric acid concentration, and is finally adjusted to $0.4 \underline{M}$ in $\mathrm{HNO}_{3}$ and $2 \underline{\mathrm{M}}$ in $\mathrm{Ml}\left(\mathrm{NO}_{3}\right)_{3}{ }^{\circ}$ 
OANL Das 74-7500

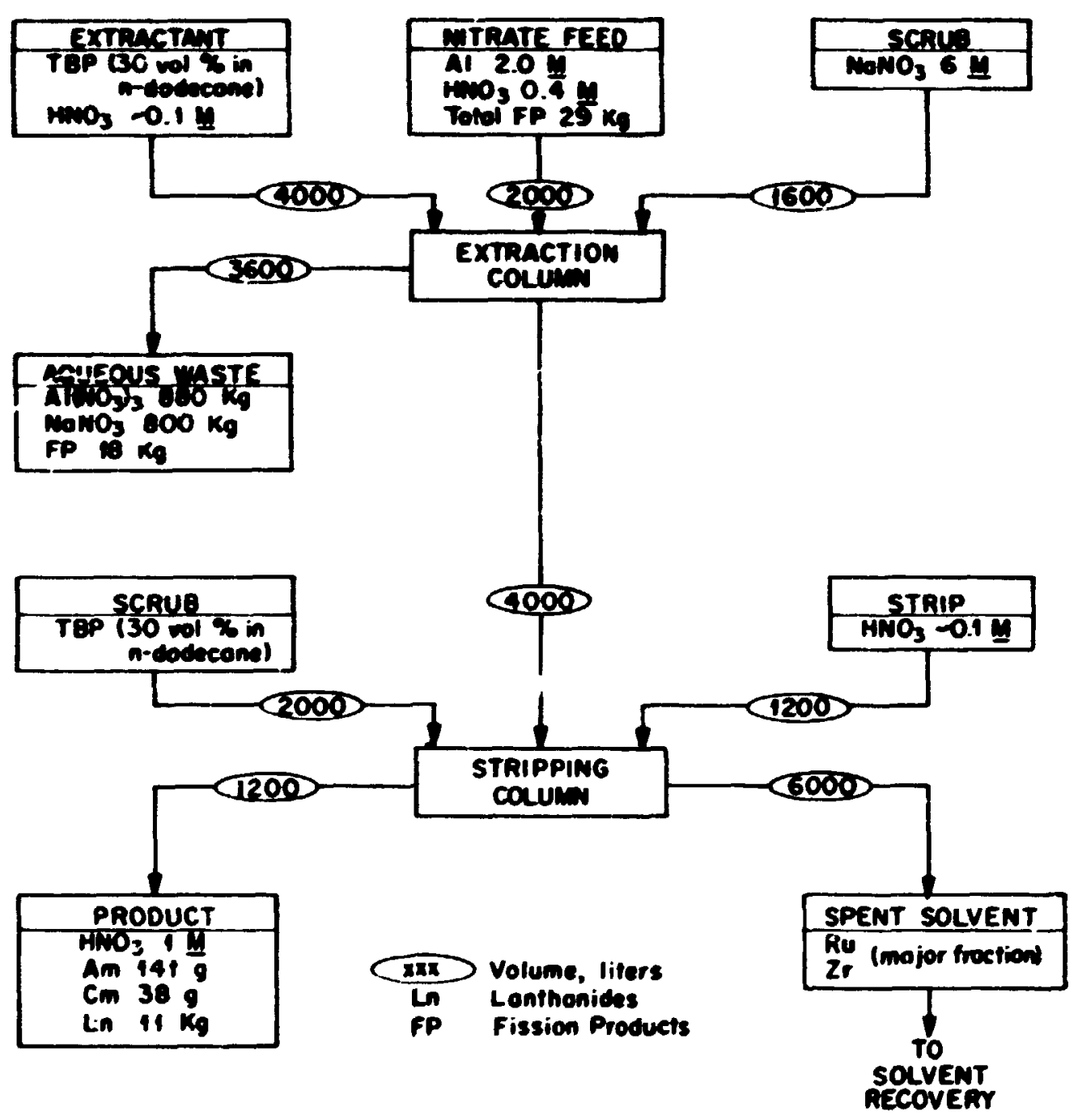

F18. 7. Conceptual florsheet for removal of lanthanides and trivalent actinides frow high-level waste by extraction with TBP from nitrate-salted solutions. 
Final adjustwent of aluinu nitrate so:utions to low acidities has been accoplished by digestion of the solution at $140^{\circ} \mathrm{C} .{ }^{21}$ The exthod used for feed adjustwent also would require development work to adapt it to the large-scale continwow operation. Becruse of the bigh radiation exposure and the fisston product content of comercial fuels, the stability of the

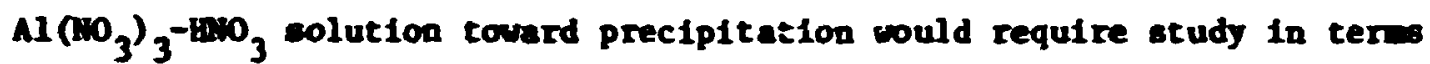
of specific fission-product concentrations and acidity.

Ion exch agse separation of the trivelent actinide-lanthenide frection. During the past two decades or so, lon exchange separation has been exployed a a general laboratory and analytical wethod for achleving group separathons of elements according to their valeace. This method appears to have the potential for isolating a trivalerat-alenent fraction fron high-level waste solutions. Ion exchange separations have not found wide applicability in large-scale processing where high-level radiation is involved because of radiation dange to the resins. However, if the vaste solutions are alloved to decay for a sultable period of tine (perhaps 5 years) prior to processing, ion exchenge my prove to be satisfactory for separation of a lanthanide-actinide fraction. Ion exchange also of fers the potential for removing residual plutoniun, uraniun, and neptuniu, which could perhaps be accomplished at the sane tive that the trivalent actinide-1anthantde fraction is separated.

A number of Ion exchang: wethods have been exployed for various fission product separations. Por example, a laboratory-scale cation exchange process has been developed fCr separating lanthanides and actinides fron other fission products. 22 However, none of the wethods was ained at the largescale separation of trivalent actinides and lanthanides from the other fission products. Ion exchange would offer an advantage over currently exployed methods in that woderately high actdities, 1 to $2 \underline{M}$, could probably be exployed in the feed, thereby avolding the generation of solids by r.ydreiysis and precipitation. Also, it would be expected that a snificant portion of the nitric acid that is used as an eluent could be recycled. It 18 11kely that the remainder of the necessary elution steps could be carried out wth organic complexing agents which could be 
principally converted to gaseous chemical wastes and thus would not increase the volume of the final calcined high-level waste. The desirable features of such an ion exchange process are sufficient to justify experimental work to deternine its feasibility.

Specific extractants for trivalent actinides and lanthanides from acidic solutions. It would be highly desirable to find an extractant which would selectively remove the trivalent actinides and lanthanides from nitric acid solutions of high-level wastes without the use of metal nitrate salting and which could be stripped to produce a moderately concentrated product. It would be preferable if the extraction could be mide at waste solution acidities of $2 \underline{M}$ or greater, where the stability of solutio.s with regard to hydrolysis of certain metal ion constituents is a minimal problem. A search was conducted for such an extractant during the process development work associated with transplutonium slement production programs. However, all the solvents that possessed this capability were found to suffer various other disadvantages, and no ajor attempt was made to overcome these disadvartages through appropriate development studies. Extractants which removed the actinide-lanthanides from low-acidity or highly salted solutions were acceptable in the transplutonium-element program because (I) the transplutonium elements are much more concentrated in the specially irradiated targets to be processed than in power reactor fuels, and (2) the required degree of recovery is considera:ly lower than that required for waste partitioning. Since the concentratiss of americium and curium in the high-level waste solutions are quite low, a solvent extraction process which would yleld a highly concentrated product of actinides and lanthanides, even without a high degree of decontamination from other fissior. products, would offer a considerable advantagr. The potential usefulness of such a prncess is sufficient to jusify a reexaminotion of extractants.

Many extractants have been studied with regard to their capability for extracting trivalent actinides and lanthanides from acid solutions, 3,23 However, any extractant which provides high extraction coefficients from solutions of moderately high acidity is apt to make stripping of the 
extracted americium and curium diffirult. Ir, such cases, the extracted species are so strongly complexed by the extractant that they can only be effectirely stripped into an aqueous phase through the use of complexing agents which form stronger complexes with the metal ions in the aqueous phase than does the extractant in the organic phase. If reagents with suitable characteristics cannot be found, the metal ions must be stripped by destruction of the extractant via certain chemical reactions such as hydrolysis or displacement with a wore extractable ion. Another disadvantage of such extractants is that they also extract the highervalent fission products, which must be subsequently separated from the lantilanides and actinides or be removed prior to extraction of the trivalent elements. These undesirable features could possibly be circumvented through appropriate process chemistry and flowsheet development vork. A process which uses the extractant di (2-ethylhexyl)pytonhosphoric acid (DOPP), in which stripping is acce mpished by hydrolysis of the DOPP, has been reported for the recovery of actinides from kilogram quantities of rock samples from underground nuclear explosions. ${ }^{24}$ Extraction was effected from a $2 \underline{M} H--3 \underline{M}$ HCl solution.

Although many extractants have been employed in the laboratory for extracting transplutonium elements from unsalted, acidic solutions, only one has found application on a significant scale. Di(2-ethylhexyl)phosphoric acid (HDEHP) can be used to extract trivalent actinides and lanthanides at low acidities ( 0.1 to $0.3 \underline{\mathrm{M}}$ ), and the extracted species can then be stripped with $2 \underline{M}$ acid. This extractant forms the basis for the Dapex 25 and Cleanex 26 processes. The Transuranium Processing Facility (TRU) at ORNL currently employs the Cleanex process, in which the lanthanides and actinides are coextracted from $0.1 \mathrm{M} \mathrm{KNO}_{3}$ into $\mathrm{HDEHP}$ and then stripped into $2 \mathrm{M} \mathrm{HCl}$. The primary purpose of the use of this process is to prepare a chloride-based feed solli:ion for subsequent separations of actinides and lanthanides, However, significant decontamination from other fission ?roduct elevents and corrosion products is also cbtained. Since this extractinil proces 3 must be exployed with low-acidity solutions, feed preparat funs must be carefully carrled out. Solution acidity is adjusted by a 
combination of neutralization of the acid with sodiun hydroxide and dilution. This procedure yields small anounts of a precipitate which can be accomodated in the batch extraction with HDEKP. It is not known whether this precipitate coutains small anounts of actinides.

In addition to the trivaleat actinides and lanthanides, HDEHP also extrects many higher-valent elements at low acidities. However, since the extraction coefficients for the higher-valent lons are also high at higher aciditie:,, selective stripping of the trivalent actinides and actialdes might be carried out after coextraction; another possible approach would be to renove the higher-valent fons by extraction into HDEHP IOD $6 \underline{M}$ acid prior to the extraction of trivalent elements at low acfdity. At TRU, plutoniu and other fission products (zirconium, wolybdenum, niobium) are renoved in this manner by the Pubex process 26 before the cleanex process is used to extract the actinide-lanthanide fraction.

Selective fission product removal. The problems assoctated with recovery processes which requirt lowacidity solutions are largely a result of the presence of certain hydrolyzable fission products. hemual of these fissiol products would avold potential losses to precipitates and would aluc pernt a more-concentrated feed solution to is prepared. Fission products with valences greater than 3 also complicate the recovery of a trivalent actinide-lanthanide fraction from high-acidity solutions since they are coextracted in solvent extraction processes or are sorbed on cation exchange resins ahead of the trivalent fractions. It ay be advantageous to resove certain of these fisston products prior to the preparation of an actinide-lanthanide feed solution for final 1solation of anerictiva and curium. It would be preferable, of course, that any selected : ission product rewoval and the separation of a relatively pure o-tinide-lanthanide fraction be accumplished in the same process. Howt ver, this may no: be practirel or possible.

The flssion products that usually presen problems in americium and curtun recovery processes are zircontum, molybdenum, and noble metals. of course, others any also cause difficulties at the concentrations present 
in higher-burnup fuels. In sume instances, removal of the fission product(s) ay be required either to avoid troublesone precipitates or simply to allow the preparation of a mre-concentrated feed solution of lanthanides and actinijes.

Processes for selected fission-product removal should only be developed as circustances dictate. Extractants are available for resoving some of the troublesome fission products. For example, HDEHP Extracts zirconiun, wlybdenum, and niobiu from $6 \underline{M}^{\mathrm{H}} \mathrm{HNO}_{3}$, as described in tise previous section. On the other hand, a significant proulea to be resolved with the use of HDEHP is finding a practical wethod for stripping the fission products so that the solvent can be recycled.

Certain fissicn products such as zirconiw and wolybdenum are effectively extracted by TBP along witin the lanthanides and actinides fros 12-16 $\mathrm{M} \mathrm{HNO}_{3}$, and $1 \mathrm{t}$ way be possible to effectively partition the extracted materials by selective stripping techniques. Although ion exchange techniques are also potentially atcractive for the removal of various fission products, they appear to be wore applicable to the separation of a lanthanide-actinste fraction fron the reainder of che fission products as previously discusz:ed.

\section{CONCEPTUAL PROCESSES FOR REMUVING ACTINIDES FROM HIGI-LEVEL WASTES}

Investigation thus far indicates that the rewoval of actinides can best be accomplished by inproved recovery of actinides in conventional fuel reprocessing plus secondary treatment of the high-level wastes. Both the conceptual processing sequence for rewoing the actinides and the processes for their renoval are presently being studied.

\subsection{Processing Sequence}

The pressnt version of the processing sequence for removing actinides dur..ng LWR fuel reprocessing is 1llustrated in Fig. 8. According to this concept, neptunfur would be recovered along with the economic values of 
ORNL DWG 74-3054R

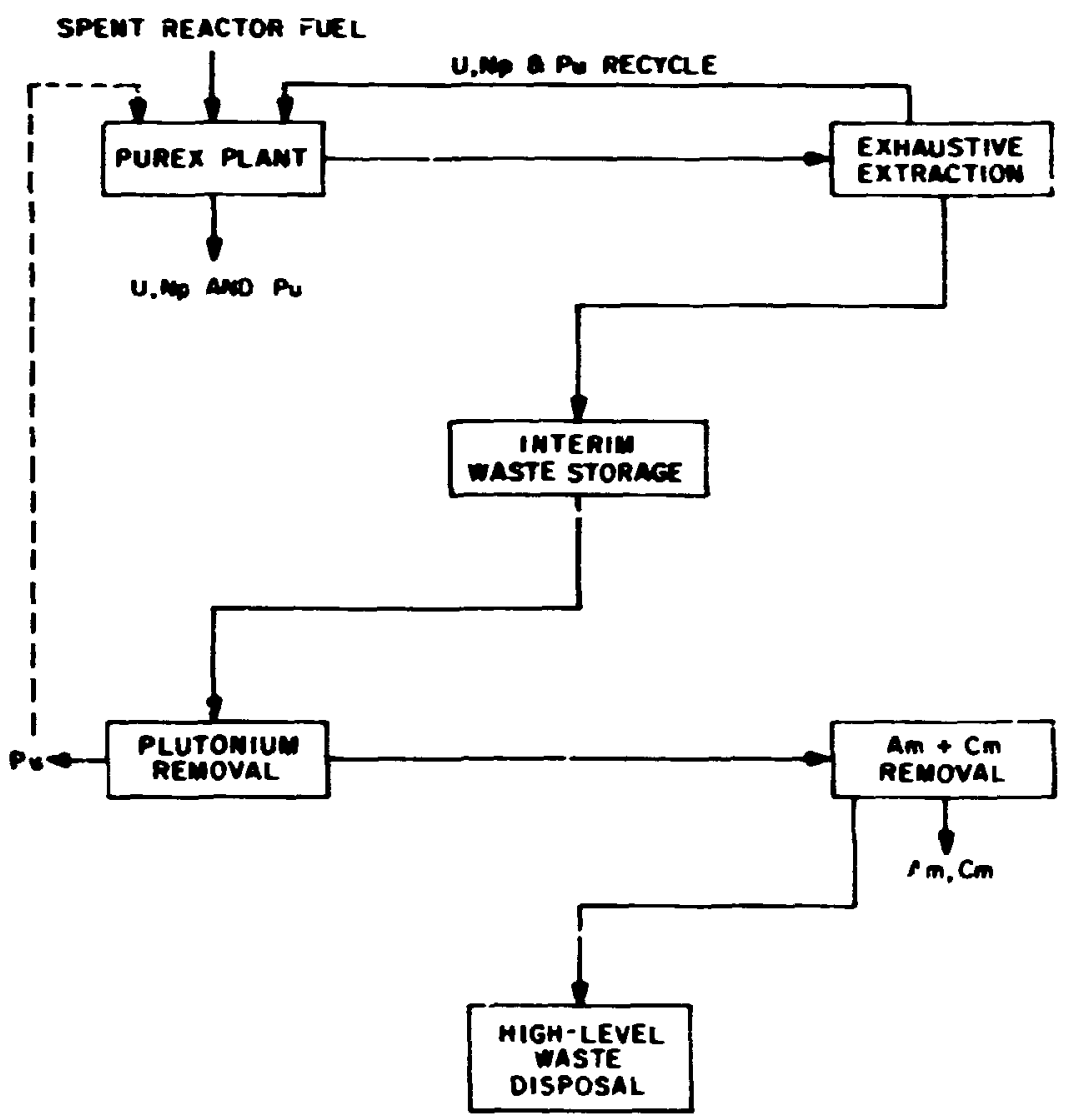

Fig. 8. Conceptual processing sequence for the removal of actinides from LWR reactor fuel. 
uraniue and plutonius in the primary Purex plant. If technically feasible, essentially conplete removal of the reactor-bred plutonium, uranium, and neptunium would be acc moplished by mans of a lditional extraction stages or an adfitional cycle of the Purex process. Next, the hign-level wastes vould be stored for a certain period (up to seyeral years) in order to reduce the radiation damage to reagents in subsequent processing. In the next step, as presently visualized, any inextractable plutonium remaining from the exhaustive extraction step and the plutonium daughter from curium decay would be removed. The americium and curium would be isolated following the final removal of plutonium.

5.2 Recovery of Uranium, Neptunium, and Plutonium by th: Purex Process in the Fuel Reprocessing Plant

It is expected that a reptunium recovery of 95 to 997 can be obtained in the fuel reprocessing plant, along with an improvement in the usual uranium and plutonium recoveries. Insolubl: residues from fuel dissolution would be separated and processed in a secondary dissolver. Additional improved :ecove: $;$ of uranium and plutonium would be obtained by recycle of the aqueous waste stream from the uranium, neptunium, and plutonium purification cycles. It appears that recycle of the aqueous waste streams from the purification cycles would increase recoveries of uranium and plutonita to as mucn as $99.8 \%$ and $97.5 \%$, respectively. Recoveries obtained in the coextraction of uranium and pluconium in the first extraction column at NFS have been as high as $99.97 \%$ uranium and $99.7 \%$ plutonium during some operational periods in the Yankee fuel campaigns, 8 indicating that the Purex process has at least this potential.

Considerable development work will be required in order to achieve the desired recovery of neptunium and the improved recovery of uranium and plutonium. For instance, methods for maintaining the neptunium valence during extraction require further study. Also, an alternative reductant for ferrous sulfamate, which is used in partitioning uranium, neptunium, and plutonium, will have to be developed in order to accomplish the necessary recycle for improved recovery and to eliminate sulfate ion, which interferes with the subsequent processing of the wastes. 


\subsection{Additional Recovery of Uraniu, Leptunium, and Plutoniu by Exhaustive Extraction}

Essentially coplete resoval of urante and neptuniu is expected to be accouplished in the additional stages of Purex extraction. It is not possible to estinate what fraction of the residual plutoniun will be resoved since neither the anout nor the nature of the inertractable plutonitu is known. The saall quntity of actinides removed by the exheustive extraction will be recycled to the primary Purex extraction to awid the necessity for extra purification cycles for fission-product decontanination. Also, it is expected that a high decontanination from fission products will wot be necessary during the exhaustive extraction since the recycled actinides are coextracted under conditions where good fission-product dr ntanination is achieved.

\subsection{Interin Storage of High-Level Hastes}

Fission product yetriun and rare earths are associated wth anericius and curtin throughout most of the processing; therefore, radiation danage to chencsil reagents, resins, and solvents will be quite high unless the waste is allowed to decay for a suitable tine prior to processing. The bulk of the activity in the rare-earth fission products is primurily due to ceriun and its daughter praseodyaiu, and to yttriu (Fig. 9). The only other rare earths of sadiation significence are europiu and pronethiun. The theral power of 1-year-decayed yttriw and rare earths is reduced by factors of about 3,6, and 9 at total decay times of 3, 5, and 10 years, respectively. In 10-year-decayed waste, essentially all of the radiation associated with rare-earth fission products (977) is actually due to yttrium. Taking these facts into consideration, storage tines of 10 years or greater would give considerable advantage in the processing. However, current USAEC regulations require that the wastes be solidifled within 5 years and that the solid wastes be assigned to the USAEC for manageme within 10 years. It would be desirable to recover the americium and curium before the vastes are so: tdiffed to avoid the necessity for redissolution. Material such as $\mathrm{Al}_{2} \mathrm{O}_{3}$, which way be added to stabilize the wastes and ake them difficulty soluble, wll complicate processing. 


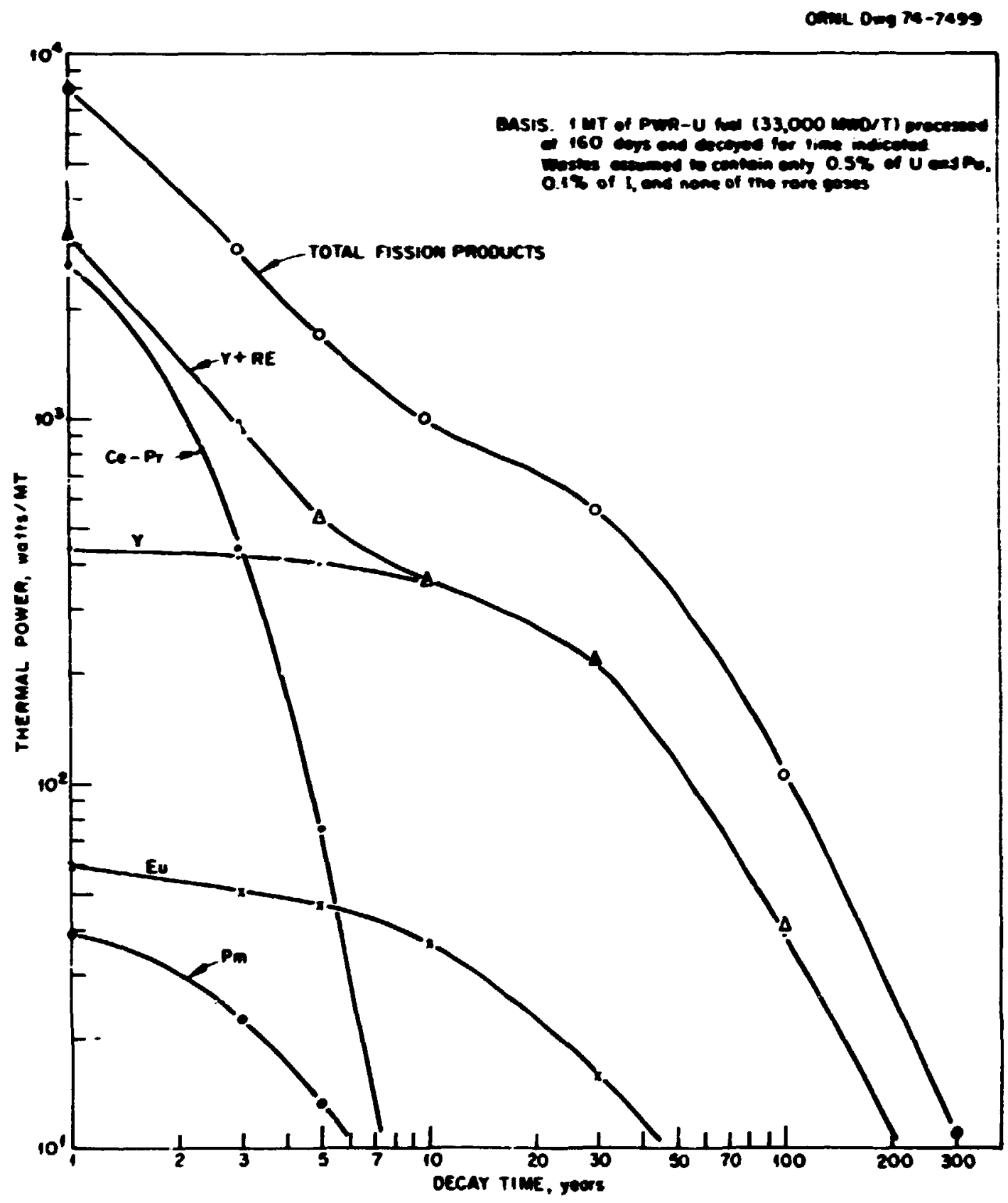

Fig. 9. Thermal power of high-level waste from the conventional reprocessing of LWR fuels. 
Developmental tork will proceed with the assumtion that americium and curiu will be recovered after the 5-year maximum permissible periof for storage of liquid high-level waste. The effect of processing at shorter times will also be investigated.

Storagt of the waste also presents significant disadvantages. For example, large inventories of liquid will be accumalated, solids will for during storage, and piutonium that grows back into the waste f:om curium decay vill again require removal. About $9 \mathrm{~g}$ of plutonium (primarily ${ }^{240} \mathrm{Pu}$ ) would "grow into" the waste from each meiric ton of fuel by decay of curium during the 5-year strrage period. Since plutonium will definitely have to be removed after the storage period, it is not certain at this time whether there is any advantage in atcempting to obtain complete plutonium rewoval prior to storage. An all-ion-exchange process has the potential for recovering the plutonium, aiong with americium and curium and perhaps also the neptunium and uranium. However, it seems advantageous to rercver the required amount of uranium and neptunium by extra Purex stages since that process is already employed and has the potential $f, r$ the necessary degree of recovery. Although additional plutonium will also be extracted in these extra stages, it is doubtful that complete extracticn will be obtained because of the presence of inextractable forms of plutonium.

\subsection{Removal of Inextractable and Daughter Flutonium}

The type of processing required for this step cannot be determined until the nature of the plutonium in the aged wastes is determined. It will probably involve a chemical treatment to convert soluble but inextractable plutcuium (colloids or complexes) to extractable species and a solids removal step to remove actinide-bearing solids for subsequent treatment. If feasible, these solids will be dissoived in nitric acid or leached free of actinides by nitric acid and the solution recycled to the Purex process. However, if this is not feasible, the solids might be processed ir. a special manner by the use of nitric-..ydrofluoric acid mixtures or molten salts. Any solubilized, but inextractable, forms 
of plutonium such as plutcniun polyer or complex ions which eas exist will present a difficult probles and will require developmental work so that the inextractable forms my be identified and the necessary methods for rendering then extractable can be developed.

\subsection{Removal of Anericiu and Curiu}

The americium and curium will be recovered following final removal of the plutonium. The specific process that will be used for recover; cannot yet be designated and must be developed. Existing processes for the rewoval of asericiun and curiu from fission products are deficient from several points af view; although several of them are potentially promising for use as the final resoval step in which the americium and curium are to be separated from the lanthanide fission products, thods for preparing a satisfactory feed solution will have to be developed. Conventional processes for separating anericiu, curiun, and lanthanide from gross fission products utilize high concentrations of metal salts; thus it will be necessary to devise methods for elininating these salts from the final fission product waste or to develop a corplecely different process as an altemative.

Two processes that are currently being evaluated for the final removal of americium and curium from the lanthanides are CEC, ${ }^{12-14}$ in which separation is accomplished by chrometographic elution from cation exchar, ge resin; and Talspeak, ${ }^{15,16}$ in which removal is effected by solvent extraction from carboxylic acid solutions. Methods that are being evaluated for the preparation of suitable actinide-lanthanide feed solutions for these processes include:

(1) ion exchange,

(2) TBP extraction of 1 anthanides and actinides from solutions salted with aluminum nitrate, and

(3) solvent extraction from acid solutions of fission products. All of these thods were previously discussed (see Sect. 4) in light of their potential for recovery and specific problems associated with their use in high-level waste processing. Each method presents difficult 
probleas relative to preveation of losses of ectinides by hydrolysis ad precipitation and in the hadling of the waste streans generated by the mericion and curite proceasing. Prevention of the formation of solids in the cericion and curtu processing wil be difficult, and the probles associated with separating ad proceselig solids any again be enc sutered. As development studies proceed, it ay be possible to conbiae the separated solids from all sources in the overall processing of the higb-level waste, ad to recover any actinides from the combined solids. A sufficient anout of experimental data regarding the nature of the gemerated soilds will have to be obtained before such a concept can be evaluated with respect to the overall processing requifements in remoring actinides fron wastes.

\subsection{Recycle of Uaste Streses Generated in the Processing}

Satisfactory recycle of process chenicals and liquids appears to be feasible in conceptis? processes in which ifproved recovery of uraniun, plutoniun, and nepiuniu is achieved by modifications and additions to the Purex process. The feastbility of recycling vaste streas generated during the rerovery of merlctum and curiun has not been deternined, and development of the necessary mods will require a substantiai research and development effort. The ability to satisfactorily handle the vaste strean from processes designed to remve inextractable and daughter plutoniue after vaste storage 18 unknown and aust await development of the processing that will be exployed to effect plutoniun rewuval.

Conceptual flowsheets for the recycle of aqueous waste streaus from the Purex process were evaluated in some detall with regard to the minline processing and exhaustive extraction (see Sect. 8). Solutions to . specific probless assoclated with the solvent purification and recycle were not included in the flowsheets and require further analysis. 


\section{MJOR PROBLERS TO RE SOLVED}

Several difficult chenical problems will have to be solved before the technical feasibility of actinide removal can be deternined. In addition to the undissolved residues in fuel dissolution, these problems largely sten fron stenical changes that occur in solutions of actinides and fission products during convertional and additional processing and during the recucle of generated waste streans. Major problems that have been identified include the following:

(1) elimination of actinide losses 1.0 undissolved resides of fuel and to solids generated in the processing,

(2) identification and recovery of itextractable forms of plutoniun,

(3) development of an asericium-curium remoal process,

(4) development of alternative reductants of uranium, neptunium, and plutorium partitioning,

(5) control of neptunium valence during extraction,

(6) satisfactory recycle and management of waste streams generated by the processing.

To a large extent, these problens are interrelated.

\subsection{Undissolved Residues of Fuel and Solids renerated in the Processing}

Attainwent of a high degree of recovery of actinides from spent fuels by chemical reprocessing, and heis:s their elimination from the high-level waste, will require that losses caused by undissolved residues of spent fuel and solids generated in subsequent separations processes be aroided or reciuced to very small levels. Losses that have been experienced in reprocessing plants with tal-clad oxide fuels have not been adequately reported, and little information is avallable from the literature. Solids have been a problem not only because they represent a lnss of fissile material, but also because they often cause operational difficulties. In a previous study, ${ }^{3}$ the literature was surveyed with regard to the 
nature of the sclids to be expected fron fuel dissolution and, in a broad sense, this survey helped to identify difficulties that can be expected as a result of these solids.

Results of experimental studies have shom that the insoluble residues from the dissolution of various fuel elements consist primarily of undissolved core waterials and some insoluhle cladding oxides, and that ihe quantity of insolubles increases as the burnup of the fuel increases. Leaching the residues with nitric acid that contans catalytic amounts of fluoride ion has been shown to be effective in reducing the losses of plutonium to these residues. Insoluble residues that have been identified from the dissolution of $\mathrm{PuO}_{2}-\mathrm{UO}_{2}$ fuels predoninantly contain wolybdenum, zirconium, niobium, ruthenium, rhodium, and pailadium. Losses of plutonium to these residues have been reduced to a few hundredths of a percent in small-scale leaching tests on irradiated fuel pellets after secondary treatrent of these solids with $8 \stackrel{\mathrm{M}}{\mathrm{HNO}} 3^{-0.05} \underline{\mathrm{M}} \mathrm{HF} .{ }^{27,28}$

In large-scale processing, undissolved fuel fines and insoluble residues emerge with the exiting liquid from the dissolver. These materials are suspensed via agitation of the solution by the nitric oxide gases generated in dissolution and by the flowing liquid. Separation of these solids may be difficult.

Even if the actinides are successfully removed from the fuel dissolution residue, solids may again be generated in subequent processing or during storage of the high-level wastes. In the past, solids may have been generated siuply because of aging that occurs while the processing is being carried out. Some of the fission products are hydrolyzed, precipitating slowly and somewhat irreproducibly.

A considerable amount of definitive work will be needed to identify the solids, the conditions by which they are generated, and tise actinide losses associated with them. In cas:s where the formation of solids cannot be prevented, methods for handling these solids and fcr recovering any actinide values associated with them will have to be developed. It is expected that a large fraction of the definitive work can be accomplished 
with synthetically prepared waste solucions and wastes prepared frow the dissolution of smal: irradiated fuel specimens.

\subsection{Inextractable Plutoniun}

In the past, the compleze recovery of plutoniun has been inhibited by the presence of inextractable forms. These consist of fuel dissolution residues and of furms generated during processing, not yet icertified, which may iluilude colloids, precipitates, sorbed species, and complex ions. Data repoit.ed by workers at Karlsrut:e 29 indicate that plutoniun becomes inextráctable after repeated Purex extraction cycles when concentrations of $0.8 \pm 0.4 \mathrm{mg} / \mathrm{ml}$ are reached. This amount of inextractable Dlutonium calculates ti be $4 \pm 2$ ger metric ton of ill fuel processed or about $0.05 \%$ of the plutonium in spent LWR fuel, assumirg that 5000 liters of unconcentrated high-lavel waste is produced per ton of fuel processed.

Developmental work will be required tu identify the inextractable forms of plutonium and the mechanisms '2y which they are produced. Process conditions which favor the formation of colloidal or polymeric plutonium must be avoided since such material, once formed and aged, does not readily redissolve in nitric acid. Steps where polymer is likely to be produced include stripping of plutonium from TBP with low-acidity solutions ( $<0.2$ M) or "localized dilutions" where low-acidity condensate is allowed to drip into plutonium solutions during concentration via evaporation.

\subsection{Development of an Americium-Curium Removal Process}

The development of a satisfactory process for the removal of americium and curium is probably the most formidable task in the fractionation of high-level waste. Attainment of the necessary recoveries at the low acidity conditions that are dictated by the separations processes will require either drastic modífications of present processes or an entirely new approach. Also, the types and amounts of process reagents that are used must be closely scrutinized with regard to their amenability to recycle and minimizing the final volume of high-level waste. 
Some of the processes that ara avallable for the fialal isclation of ancriciun and curiu fron the chenically sinflar lenthinide ftssion products appear so have the required potential. However, the feed to the process ast be essentialiy free of the other fission products. Existing processing wethods for the recovery of arriciu and curiu from solutions of fission products will not meet the overall requiremeots of waste fractionation. The available processes and their linitations were previously discussed in Sect. 4.2.

\subsection{Altemative Reductants for Uranisa, Meptuniun, and Plutoniun Paxtitioning}

Ferrous sulfanate, Fe $\left(\mathrm{NH}_{2} \mathrm{SO}_{3}\right)_{2}$, is used in the Purex process for reducing Pu(IV) to Pu(III) in the partitioniag of plutoniu fron uraniun and neptiniu and in the subsequent purification cycles of these actinides. This reductant introduces iron and sulfate, both of which interfere with rerycle of the aqueous wastes from subsequent purification cycles and ulticately appear in the high-level waste. Although the iron is not necessarily objectionable, the sulfate forms complex fons with plutoniu which interfere with plutoniun recovery in subsequent cycles of TBP extraction or ion exchange ard also increase :-ortosion in stafnless steel equipwent. The difficulties caused by ferrous sulfanate are magnified as the plutoniu content of reactor fuels is increased and wre reductant is required. The probles of reductants is recopnized in the reprocessing of LMFBR fuels, and altemative reductants are also under study in that program. ${ }^{7,30}$ This problea is even wre acute in waste fractionation because chemicals which prevent the extractability of the residual plutoniun or other actinides fron the high-level vaste cannot be introduced into the primary Purex plant. Such reductants would seriously retard, if not prevent, significant ipprovenents of plutonium recovery in the Purex plant and in recycle of the concentrated aqueous wastes from the purification cycles (see Fig. 4, Sect. 4.1.1).

Chemical reductants that appear to be the wost pronising in the partition cycle are $U$ (IV) or ferrous nitrate solitions that are stabili Led by hydrazine. 7,30 Electrolytic reduction may be an even wre de'sirable 
alternative. In the BPIP, plutoniu: will be electrolytically reduced in the aixed phase in the solvent extraction equipment. 31 studies of potential electrolytic processes have been initiated at $\mathrm{ANL}^{32}$ and Karlsruhe. ${ }^{33}$ Hydroxy lamine nitrate (ㅂN) has been substituted for ferrous sulfamate in the second plutonim cycle where plutonium is strippe 1 under conditions of low acidity. However, HAN is ineffective in the partitioning cycle where the aqueous-phase acidities are uch higher because of the slowness of reduction. Ferrous nitrate is needed in moderate concentrations to calalyze the reduction of $\mathrm{Pu}(\mathrm{IV})$ by $\mathrm{HAN}$ and has been reported to be sufficiently rapid to be effective in the partitioning of plutonium. ${ }^{34}$

A series of tests was rade in the Hanford Purex Flant to coupare the performance of several chemical reductants with that of ferrous sulfamate. 35 Uranium(IV)-hydrazine and fezrous nitrate--hydrazine were found to be effective reductants in the partitioning cycle. Ferrous nitrate--hydrazine was also successfully substituted in the second uranium cycle and in the sacond neptuniual cycle. HAN was demonstrated as an acceptable reductant in both the second plutonium cycle ${ }^{36}$ and the second uranium cycle. Uranium(IV) nitrate has been demonstrated as ail effrestue reductant in plants at several European installations. 37

Difficulties have been encorritered in some of the operations with these alternative reductants. Most of the difficulties were reportedly associated with controlling the concentration profiles of reductant or hydrazine in the extraction columns that are necessary for successful operation, and with mainiaining stability of $U(I V)$ nitrate solutions. Although further developmental work is needed befcre a practical operating prosess can be realized with these altemative reductants, their general feasibility has been adequately demonstrated. Electrolytic reduction processes will also require further study. It would be of rinsiderable advantage to generate a chemical reductant such a.s U(IV) or Fe(II) in situ if this could be accomplished without producing other undesirable electrode reactions.

It 18 necessary that the behavior of any alternetive reductant be satisfactory in regard to the reduction of $\mathrm{Np}$ (VI) in the Purex proceas, 
since reductarics that reduce $P u(I V)$ also reduce $N_{P}(\mathrm{VI})$. In the partitioning of plutonium from neptunium and uranium, it is necessary that neptunium be reduced completely te $\mathrm{Np}$ (IV) so that it remains in the TBP phase with the uranium. In this step, the reduction rate wast be sufficiently rapid to prevent $\mathrm{Np}(V)$ from beirg discharged with the partitioned plutonium. Ferrous ion and $\mathrm{L}(I \mathrm{~V})$ in appear to be satisfactory for preventing neptunium from entering the plutonium stiean, but experimental work is needed to determine the choice of conditions.

\subsection{Control of Neptunium Valence in Coextraction}

In the coextraction of reptunium, uranium, and plutonium from nitric acid jolutions of spent fuel by the Purex process, tite neptunium is extracted as $\mathrm{Ip}\left(\mathrm{V}^{\top}\right)$. Sieptunium is maintained in the hexavalent state by means of the nitrous acid-catalyzed oxidation of $\mathrm{N}_{\mathrm{p}}(\mathrm{V})$ by nitric acid. The chemical equilibriun between $\mathrm{vp}(V)$, whith is inextractable in TBP, and $i p(V I)$, the preferred extractable state, is given iy the equation $\mathrm{NpO}_{2}^{+}+3 / 2 \mathrm{H}^{+}+1 / 2 \mathrm{xO}_{3}^{-}+\mathrm{NpO}_{2}^{2+}+1 / 2 \mathrm{HNO}_{2}+1 / 2 \mathrm{H}_{2} \mathrm{O}$.

The hexavalent state is favored by high acidity and low $\mathrm{HNO}_{2}$ concentration. ilowever, catalytic anounts of $\mathrm{HNO}_{2}\left(>5 \times 10^{-5}\right.$ M) are required to obtain practical oxidation rates. The oxidation rate is increased by increasing the temperature and the nitric acid concentration. There is a limit, however, of the extent to whicis nitric atid concentration can be increased sithout sericusly affecting fission product decontamination factors. In rractice, satisfactory rates of oxidation of $\mathrm{Np}(V)$ during extraction are obtained at concentrations of 2 to $3 \mathrm{MNO}_{3}$ and $10^{-4}$ to $10^{-3} \mathrm{M} \mathrm{HNO}_{2}$ and at an extraction temperature of $45^{\circ} \mathrm{C}$. The required nitrous acid is generated by adding sodium nitrite to the acidic system.

One of the major difficulties in oblaining good recoveries of neptunium involves maintaining the necessary nitrous acti concentration profile throughout the many stages of countercurrent extraction. ${ }^{9}$ This difficulty is caused by two factors. First, nitrous acid is highly extiactable by $\mathrm{TBP}$ and control of the $\mathrm{HNO}_{2}$ concintration in the aqueous 
phase requires additions that offset the losses by TBP extraction. Second, nitrous acid is required in feed preparation to ensure that any $\mathrm{Pu}(V I)$ is reduced to $\mathrm{Pu}(\mathrm{IV})$ so that plutonium is in its most extractabie state. This further complicates the neptunium valence adjustmert process, since the amount of titrous acid necessary to reduce the plutoniur: is highly variable. The amount of Pu(VI) ismed during dissolution increases with boiling time and ferric ion content of the solution, ranging typical: fros 10 to $50 \%$ of the total plutoniur. ${ }^{\top}$ The amount of Pu(YI) will ais: se related to the plutonium content of the fuel and the radiation density o: the fuei solution. It is probable that the amount of $\mathrm{Sp}(\mathrm{VI})$ forned durisg dissolution is also variab?:. Suitable nethods will have to be cevelept: for adjusting the plutonium valence in the feed and stiil mantaining the nitrous acid concentration required for neptunium extraction. Overail, a significant amount of developtent work will be needed to deanstrate tie capability for maintaining control of the feed compsition and extraction column concentration profile necessary ic routinely achieve a high recovir of neptunium at the reqiaired processing rate.

Because of the irirge quantity of sodium nitrite required to adjust plutonium valence in ccrcentrated plutonsum solutions and its ultimate contribution to the high-level waste, alternative reagents are currents being evaluated in the LMFBR program. Bubbling No or $\mathrm{NO}_{2}$ gas through dissolver solutions and electrolytic reduction are being considered as attractive possibilities. Either of these methods is probably compatible with subsequent adjustment of conditions for neptunium extraction.

\subsection{Recycle of Waste Streams}

The development of acceptable concepts and methods for the recycle of waste streams generated by the processes used for removing actinides from high-level waste will require a major effort. The americium and curium removal processes will present the greatest difficulties with recycle because of the nature and amounts of reagerits that are required (see Sect. 4.2). The processing of the high-level waste must be carried out in a manner such, that any generated waste streams which do not meet 
$10 \mathrm{CrR} 20$ regulations are recycled or are arenable to concentration and combination with the high-level waste. All recycle concepts will require evaluation with regard to the potential for buildup of impurities in sustained operations that are detrimental to certain process steps.

It appears that recycle wethods can be developed for the varlous Purex process steps in the conceptual sequence of actinide removal. The nitrir acid can be recovered by distillation, and the actinides from the purification vaste strean can be recyclod if acceptable redustants are used iu the partitioniug of uranium, neptuniun, and plutoniun (see above and Sect. 8). Methods for satisfactory recycle of the :01vent can probably also be developed so that waste srreans fron the purification can be recycled to the Purex process.

Studies will have to be carried out to deternine the exter.t of recycle and treatment of waste $s$ reans expected from the candidate processes fur americium and curium recovery. The resu, $-s$ obtained in these studies will be a governing factor in selecting the ultinate process for curium removal. Any chemicals required in the retwoval processes will have to be carefully evaluated as to satisfactory methods for their removal as chemical wastes or for recycle. Process chemicals which can be recycled via purification by distillation or which can be converted to volatile, noncontaminated wastes by chemical reaction or combustion methods would appear to be the most desirable. Spent ion exchange resins, organic complexing agents, volatile mineral acids, and badly deteriorated solvents can potentially be handled in this manner.

Methods which employ large quantities of relatively nonvolatile metal nitrate salting agents cannot be ruled out at this time. It may be possible to develop methods for satisfactory recycle of these materials by crystallization of the salts, or for reducing the awounts required tc acceptable levels for combination with the high-level waste. 


\section{LABORATORY STUDIES ON PROCESS DEVELOPYENT}

Experimental studies have been faitiaced relative to the tentative conceptual flowsheet (see Fig. B, Sect. 5.1) for removing actinides from high-level waste, and to eajor problens that nust be solved to exploy this fiowsheet. Thus far, synthetic waste solutions have been used in these studies (see Appendix E). Scoping studies are being carried out for removal of americium and curium irom high-level wastes by solvent extraciion and by ion exchange. Although no experimental work has been performed to date, ralcul itions of the approximate conditions for neptunium recovery by the Purex process have been wade from published data. These caiculations vere performed preparatory to laboratory experiments in which conditions for coextraction of uranium, neptunium, and plutonium and their subsequent partitioning will be investigated.

\subsection{Removal of Americium and Curium from High-Level Wastes}

Several process methods have been used to recover americium and curium from fission product wastes; however, the je methods are not directly applicable to waste fractionation. Pecoveries of only 90 to $99 \%$ are achieved, and the large amounts of chemical reagents required $8 \mathrm{r}$ atly complicate the treatment and disoosal of the wastes. In most of the wethods, the rareearth fission products (which constitute about one-third of tne fission products by mass) are recovered along with americtum and curfum; therefore, an additional process step is required to remove the americtum and curium from the rare earths. Moreover, the processing experipnce on the separation of americtum and curfum from lanthantdes has been obtained, for the most part, with specially irradiated targets where the mole rat10 of rare earths to trivalent actinides is about 20 , whereas in typisal LWR fuels the ratio Is about 100 .

Both solvent extraction and Ion exchange techniques ars being investigated for removal of americium and curium from high-level wastes. A sufficient number of exieriments will be carrled out $:$ permit a fudiclous celection of the processes necessary for removal of arericium, curium, and 
rare earths from the waste and for their subsequent separation. Involved in this choice is the preparation of detailed flowsheets wich include recycle or any special treatmeat required for each waste strean generater? in the processing.

\subsubsection{Solvent extraction process ethods}

Solvent extraction is being considered for use in rewoving trivalent actinides and rare earths from the high-level waste and for the subsequent separatior of the two groups of elenents. Separation of anericiun-curiu and the rare earths from waste solutions has been studied with TBP and HDEHP as extractants. Also, the Talspeak process has been investigated for its potential applicability to this separation. Results of experimental studies made to date have revealed a numer of problems that must be solved before these separations methods can be satisfactorily employed in waste processing. A centative conceptual frocess based entirely on solvent extraction has been proposed, and the areas requiring further work have been defined.

Extraction of americium, curium, and rare earths from waste solutions. Two extraction methods were tested for their potential applicability in preparing acceptable feed solutions of actinides and lanthanides from synthetic waste solutions. The literature data indicate that separations based on TBP or HDEHP as extractants might bi feastble.

TBP is a moderately strong extractant of trivalent elements from high concentrations of nitric acid. Data in the 1 iterature ${ }^{38}$ confirmed and extendef in our experimental work indicate that americium and curium can be satisfactorily extracted into undiluted TEP from $16 \underline{\mathrm{M}} \mathrm{HNO}_{3}$ in ten or more equal-volume extraction stages and can then be stripped into a more dilute nitric acid solution. However, thus far we have been unable to obtain an americium-curium-rare-earth product that is free of fission product molybdenum. (Molybdenum would probably cause the formation of precipitates in the subsequent separation of americium and curium from the rare earths,) when $12 \underline{M}$ HNO $_{3}$ was used as the stripping agent, zirconfum 
remained in the IBP but wolybdenum was stripped along with the trivalent elewents. Although all stripping conditicns were not explored, it does not ampear that a IBP procesc with nitric acid as the only saliing agent has the capability for rewuing both zircorium and wolyjder.un :rom the trivalent actinides and rare eartis.

It is possible that such a process could be used in conjunction vith sowe, ther precess for rolybdenum removal; however, this sould act je desizable if a satisfactory single-step metrod could be developed. ilso, solvent extraction processes that euploy modified TBP and high acid concentraticns present many difficulties ir. practical operations. Phase separations are very slow because of the swall dersity difference between phases and of the high viscosity of the undiluted IBP. In addition, the solubility of TBP in nitric acid is somewhat nigh for a large-scaie solvent extraction process, and significant losses or TBP by hydrolysis wou:.d be expected to occur at the high acidities employed.

As predicted from the literature, zirconium and molybdenum are readily extracted into HDEHP from waste solutions. For exampls, they are extracted intc $1 \underline{M}$ HDEHP in diethylbenzene (DEB) from $6 \mathrm{MHN}_{3}$ with only a few stages of extraction. An aqueous solution containing the trivaient actinides, rare earths, and other fission products is obtained. This solution may be suitable for the preparation of low-acidity feeds necessary for the final removal of the americium and curium, but this remains to be demonstrated. nther major difficulties to be overcome in the use of HDEHP involve the purification and recycling of this extractant, as previously discussed in Sect. 4.2 .

Separation of americium and curfum from the rare earths. Talspeak is the only solvent extraction process that is currently being studied in the laboratory for the separation of americium and curium from the rare-earth fission products. In this process, the separation of trivalent actinides and rare earths is accomplished by coextracting the two groups of elements into HDEHP from a carboxylic acid solution and then partitioning the trivalent actinides into an aqueous phase by stripping the HDEHP extractant with an aqueous, carboxylfc acid solution containing the complexing agent 
DTPA (see Fig. 6, Sect. 4.2.1). The trivalent elements are strongly extracted into betip from various carbonglic acid solutions. (Formic, acetic, proplonic, malonic, and lactic acids have been show to be effective. ${ }^{15,16}$ ) Fonic acid appears to be an atcractive extraction rediue for the developeat of a satisfactory process for preparing a carborylic acid feed solution for the Ialspeak process. Formic acid has often been used for the chenical destruction of nitric acid and nitrate ion in the preparation of feed solutions for solvent extraction, and a considerable anount of research has been carried out to delineate the chemical reactions involved. Kolarik and co-workers 17 at Karisruie have used this whod to prepare carboxylic acid feed solutions for Talspeak, and thej $\mathbf{z}$ results indicate that it ay be possible to adapt the process for the present application.

We have initiated laboratory studies of several of the problen areas associated with the application of the Talspeak process for final removal of anericiu and curiun in the waste processing. One of these is the conversion of nitric acid solutiuns or tivalent actinides and rare earths to fornic acid media by chenically reacting a nitric acid solution of the nitrate salts with formic actd. In addition, distribution coefficient data are being obtained for the extraction from formic acid. Considerable attention is also being given to problems associated with the Talspeak partitioning cycle and to the purification of HDEHP.

Although considierable research has been done on the destruction of nitric acid by formic actd, much work still needs to be carried out relative to scale-up. In this destruction method, the reaction of formic acid with nitric acid is usually carried out at or near bolling temperature and is effected batchwise. The stolchiometry of the reaction varies with the nitric acid concentration. For example, Healy ${ }^{39}$ renorted that one mole of formic acid decomposes two moles of $6 \underline{M}_{\text {HNO }}$, but only about two-thirds mole of $1 \mathrm{M}^{\mathrm{HNO}} 3^{\circ}$. However, our experience in batch tests indicates that about two moles of formic actd are required to destroy only one mole of nitric acid at an initial concentration of $6 \underline{M}$. The reaction rate decreases as the concentrations of the reactants decrease. A considerable amount of 
work will be required to establish the best whod for effecting this chenical reaction and controlling the exocherwic reaction. Detarled studies are yez to be carried out concerning the effect of wixing and boilup rate, skin terperature effects at beated wessel walls, and recycle of volatilized but uneacted fornic and nitric acids and of the no $x$ eases evolved by the chenical reaction.

Distribution coeffictents for the extraction of anericiu lato $0.6 \mathrm{M}$ HDEHP in DEB from 0.5 to $2.0 \underline{M}$ fornic acid solutions were found to be $>100$. Scrubbing of the extract phase with dilute foralc acid is necessary to free the extracted acriciun, curiu, and rare earths from all other elements.

Considerable attention is being given to probless directly associated with the Talspeak partitioning cycle. In earlier work, 15,16 it was observed that extraction, especially for the heavier elenats, was slow when the standard partitioning solution was 1 I lactic acid-0.05 $\underline{\text { I }}$ $\mathrm{Na}_{5} \mathrm{DTPA}$. Hence improvements in the extraction kinetics were desirable. Although increasing the lactic actd concentration to 4 I Inoved the extraction rates, this high concentration is undesirable. Substitution of glycolic actd for lactic acid was found to give satisfactory extraction rates and also to increase the distribution coefficients. Increasing the extraction temperature from $25^{\circ} \mathrm{C}$ to $50^{\circ} \mathrm{C}$ decreased the equilibrium extraction time by a factor of about 2 . Also, this telperature reduced the distribution coeffictents (organic/aqueous) by about a factor of 2 , which decreases the volume of stripping solution required by abo st onehalf. A maximum equilibrium time of $100 \mathrm{sec}$ was observed for extraction from $1 \underline{M}$ glycolic actd- $0.05 \underline{M} \mathrm{Na}_{5} \mathrm{DTPA}$ at $50^{\circ} \mathrm{C}$, which should be arlequate for a continuous partitioning process carried out in axer-settiers. Although specific distribution coefficients cannot be deternined for the partitioning cycle until optimum conditions are deternined, experiments have shown that it is possible to obtain gocd separation factors by extracting from $1 \underline{M}$ glycolic acid--0.05 $\mathrm{M} \mathrm{Na}_{5} \mathrm{DTPA}$. $h$ separation factor of about 50 was obtained setween americiun and neodymiun, which is the least-extractable rare earth. 
The optian conceutration of HDEHP in DEB is deternined by the distribution coefficients of the two groups of elements and the solubilities of rare eartins in the extractant. The solubility of ecropin in 0.6 HDELP-DEB is bbout $0.03 \mathrm{Y}$ at $25^{\circ} \mathrm{C}$; the solubilities of lighter rare earths are even less. All the solubilities are sonewat higher at $50^{\circ} \mathrm{C}$. Substituting ancther hydrucarbun diluent boes not increase the solubilicy. The volume of extractar: req̣uired will be cetereined larkely by the solubilities of ine trivalent aciarides and rare earths in the extractant.

Impurities present in cosmercial-prade HDEHP decrease the separation of anericiun and curiun from the rare earths. Most of this eifect is attributable to Dono(2-etiylhexyl)phosphoric acid (H, EHP). Tests indicate that only 1\% $\mathrm{H}_{2}$ EHP in HDEHP will decrease the anericium-europium sefaration factor from about 100 tc about 40 . I further decrease is caused $5 y$ tive presence of small amounts of polyphosphates and pyrophosphates. Our studies have show that pretreatment of HDEHP with glycolate-DTPA solutions removes the $\mathrm{H}_{2}$ EHP and possitly ocher impurities, and a method for purification of HDEHP based on this observation is now under development. Comm rcial-grade HDEHP seldom has a guaranteed purity of gredter than $90 \%$, although it is usually much higher. It may be possible to improve the complex and expensive methods of purification that have been employed previously.

Tentative conceptual process for americium-curium removal based on solvent extraction. A tentative conceptual process sequence based on ou: very preliminary laboratory investigations has been proposed for the removal of americium and curium. The brief out line of the sequence presented here serves to point out the multitude of problems remaining to be solved. For example, the process uses only one extractant, HDFHP, and assumes prior removal of uranium, nepcunium, and plutonium. In addition, the proposed sequence involves steps in which solids are removed, and thus far no work has been carried out. to determine the 1 ssses of americium and curium to these solids or the mpthods by which these solids would be handled. The zeps in the tentative process are as follows: 
(1) Evaporace the $2 \mathrm{IHN}_{3}$ soiution of waste to an $\mathrm{HD}$ concentration of 6 .

(2) Cool the concentrated waste solution, and separate the solids. The final, complece processing will have to inc:ude treatanc or recycle of these solids. The first objective in our experimencal work las to cest solverst extraction concepts on nitri: acid solutioas of americiu, rurive, and rare eirths wich also contained the solible fission products and saturation amounts of the insoluble fission products.

(3) Remve zirconiu and wolybdenum by aulistage, contercurrent extraction into $0.6 \underline{y}$ HDElP. This extraction must include scrubbing stages with $6 \underline{M}^{\mathrm{M} \mathrm{HO}_{3}}$ to prevent unacceptable lusses of americiun and curiun. Any residual Pu(IV), Pu(VI), Sp(IV), and U(VI) in the solution would be quanticatively extracted here. This extraction could perhaps serve as a satisfactory alternative to the exhaustive extraction (see Fig. 8, Sect. 5.1) if suitable stripping and partitioning methods could be developed.

(4) Treat the aqueous solution with excess formic acid to destroy all of the nitrate and to produce a feed solution that is $1 M$ in formic acid. In the laboratory, this chemical reaction is carried out at atout $100^{\circ} \mathrm{C}$ in a batch process in which the nitrate waste solution is added gradually to a HCOOH solution. Atnut two moles of $\mathrm{HCOOH}$ are used per mole of $\mathrm{HNO}_{3}$.

(5) Cool and separate the relative!y small volume of solids, which appear to be chiefly silvar, rhodium, and palladium.

(6) Extract the americium, curium, and rare earths into 0.6 M HDEHP (Talspeak extraction) frum the formic acid solution. In this step, the trivalent actinides and rare earths are separated from essentially all of the other remaining fission products. Several countercurrent stages of 
extraction, followed by several stapes of scrubbing the extract phase ufith 1 트 tCOOH, are required to achleve the necessary (299.92) recovery.

(7) Separate the aricio ad corio fron the rare earths by stripplac the extractant phase vith an aqueovs

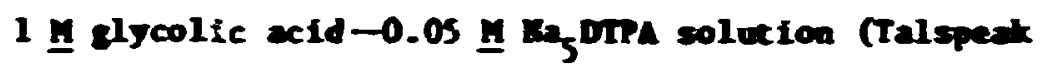
partitioning).

(8) Decover the arficion and curito from the aqueous solution. Potential methods apear to be direct oxalate precipitation, or concentration by cation exchare or Budip extraction and subsequent precipitation as oxnlates. Wo laboratory studies of this step have been car.ied out.

(9) Purit; the solvent for recjcle. Wo nethod has been devised for reoving zirconilu and molybdenu (step 3). Present wethods are unacceptable. Studies will have to be ade to deternine whether there are any technically feasible wethods that are practical.

(10) Treationt of aqueous waste streans. It may be possible to chedcally treat the high-level waste strean so that the organic acids and complexes are destroyed. However, a nuber of difficulties (e.g., foaning) way be associated with this step, and laboratory wrik will ta required to identify specific problens and their agnitude.

It nust be exphasized that this outline 18 only tentative. For example, it is fossible that an Ion exchange process (see Sect. 7.1.2) would be wre effective for preparing a feed solutio.n of actinides and rare earths for the Talspeak process. Also, wuch wore work remains before a flowsheet with quantitative specifications can be developed. Additional difficulties way be encountered in the future. In one instance, a synthetic waste solution could not be extracted with HDEHP without producing unbreakable emulsions, apparently due to a particular batch of zirconyl nitrate (of dublous quelity) that was used in preparing the waste solution. Of course, 
it is inpossible to predict wether an actual waste solxcion will behave in the san way. Furcher, the effects of corrostion products and octher chenicals that aight be present in waste have not yet been investigated. Thosphate present as the result of degradation of the Tip in the previcus processing and an flooride present as the result of its use in fol dissolution will also tead to cause precipitates in the processing. nerefore, Eethods wost be devised for their renoval as a part of the developental studies.

\subsubsection{Ion exchme process Eethods}

Experimental studies are being carried out with synthetic waste solutions to evaluate a cation exchange process for selectively reworing the trivalent elearts (rare earths and actiaides). In this process, the actinides and rare earths, along with certain other fission products in the waste solution, are sorbed on cation exchange resin. Selected reagents are then used to el ite the trivaleat actiaides and rare earths, leaving the other fission products sorbed on the colum. The eluate thus obtafned would provide a satisfactory starting solution for the Talspeak process or for the CEC processes in wich the trivalent actinides are separated from the rare earths.

Zirconiu and the noble wetals, which would interfere in the subsequen: separation of anericium and curiun, appear to be adequately remed by cation exchange. Although this treatment way not effectively separate some other elewents present in swaller arounts (alkaline earths, pertiaps), a subsequent chromatographic step for separating the actinides from the lanthas.: des would readily yield the desired results.

Radiolsotopes have been used to follow the behavior of the rare earths; also, some of the noble metals have been observed to for colored bands and solutions. However, we have not been able to deternine with any precision the behavior of any of the other components ance only a few analytical results are presently avallable for these components. In some cases, zirconium has been estimated by phosphate precipitation from concentrated nitric acid solution. 
Tize cupacity of Dowex 50-18 resin at the point where rare earths first brezic thrigh the colum (about 0.012 of the feed coacentration) is in the range of 7 co 10.5 resin bed volines of syuchetic waste (i.e., a solution, 2 in $\mathrm{EP}_{3}$, sinulating that tenerated by reprocessing irradiated ful). The higher capacities sere obtained when the solition was dilited with three volues of sater. A lowt apparene capacicy is obteined is subsecuent rus if the coluan is not choroughly iluted.

At breakthrough, the guantity of rare earths loated on the colun is in the range of 0.5 to 0.8 eq/al, increasing with the use cf core dilute feed. The resia capacity is 1.8 eq/al, and the riminder of the resin is loaded with aterials which have a stroager affinity for the resin than do the rare earths. Soble netals can contribute no writ than about 15 to 292 of the resin loading, whereas sufficient zirconicm is present to occupy over half the cocal capacity.

Winen the synthetic waste is passed through an ion exchange colum containing Lowex $\mathbf{5 0}$ resin, the trivalent eleeents, zirconium, and sone of the noble nerals are loaded very strongly. Although ocher wetals surh as barium and strontium may load as strongly, zirconium and che noble meials appear to present the most severe problem. Yost of the palladium and rhodium are in the effluent, whereas the largest fraction of the ruthenium is held by the resin. The ruthenium may be present as more than one complex species since three colored bands (presumably all of which are ruthenium) were observed to load on the resin. Results of recent tests indicate that the noble metals may be prevented from joading if appropriate complexing agents (e.g. nitrice ion or hydroxylamine) are present in the feed. These materfals, which are commonly used for valence adjustment in solvent extraction processing, may affect the valerce of the noble metals. No evidence of reduction to the metallic state was observed with these materials in acidic solutions; h.owever, hydrazine appeared to yield some metal, especially at higher pho. Hydroxylamine and nitritf form complexes with the noble metals, as indicaled isy a rather jlow change in the color of the solutions. There was no evidence of roading on che resin (i.e., no colored bands) from feet which had 
been complexed in this mantr: thus, it afpears that the interference from noble metals can hr: readily elininated.

The addition of iron (which ay be present fros equipment corrosion or parcial dissolution of fuel hardware) caused a significant decrease in resin capacity for the trivalent elemests. Wsih $0.1 \underline{M}$ iron and a two- to threefold dilution of the feed, breakthrough of trivalent ions occurred after elution of about 5 to 6 resin bed volues, conpared with about 8 when iron was absent. The effect may have been somewhat greater with ietric iron than with ferrous, but the difference was not major. The r roduct that was eluted with $3 \underline{M}_{\mathrm{HHO}_{3}}$ contained some iron in addition tc the rare earths: hovever, fron could probably be eluted selectively rith dilute oxalate solution prior to elution of the product, if this should become necessary.

Several colored bands were apparent in these tests. No rare-earth tracer (less than 0.017 ) was detected in the effluent when the most rapidly woving band, which was yellow-colored (irnn), moved of the resin bed. This band is not observed when fron is absent. The rare earths broke through when $a$ long, light-gray band (which is always observed) reached the bottom of the colum. The upper part of this bald consists primarily of zirconium plus some rare earths, while the lower part is appreciably higher in rare-earth concentration. Apparently, the fron, which is at a much higher concentration than any other weal, competes with zirconfum and trivalent ions such that it occupies apprcximately $30 \%$ of the resin and causes the aront of this mixed band to reach the bottom of the colum in less volıme than when iron is absent.

Separation of the trivalent elements from 2 irconium has been wcomplished in two ways. Elution of the loaded resin with dilute oxalic acid removes zirconium very rapldly without significantly af fecting the rare earths. After most of the zirconium has been removed, the oxalic acid also strips noble metals, yielding a solution with an extremely intense color. Suhsequently, the trivaleit elements can be eluted with nitric acid or : complexing agent to yieid i feed for the next separation step. 
Indic.itions of precipitaition within the resin bed have been observed in some cases with oxalic acid, even though the concentrations vere such that no metal oxalates were expected to precipitate. While this doez not appear to preclude use if the method, a procedure which does not produce precipitates would be preferred. Results of tests with dilute nitric acfd--oxalic acid solutions ( 0.25 to $0.1 \mathrm{M})$ were encouraging. Several other complexing agents, including walonic and aleic acids, were also Investigated; however, they did not show the selectivity of oxali= acid. Materials such as ethylenedianinetetraacetic acid, which would be expected to give a separation of zirconium from rare earths, wight be suitable, depending on the subsequent prycessing steps.

Even if zirconium is not eluted with sowe complexing agent prior to recovery of the trivalent elements, elution with nitric acid will yield a product containing essentially all the rare earths and only a very small fraction of the zirconiun. I nitric acid concentration of 3 to $4 \underline{M}$ probably represents the best compromise between zirconium separation and a reasonably small product volume. The only analytical results obtained to date fur a separation made by this method show that the rure-earth product contained less than $10 \%$ (with a substantial margin of error) of the zirconium and much less cf any other element in the waste. Such a product st.uu:t provide a suitable feed for a subsequent actinide-lanthanide separation. With rare-earth tracers, the total loss to all fractions, except the product, was easily held to less than $0.1 \%$.

A11 the resilts obtained to date indicate that a satisfactory ion exchange process ior preparing feed soluitons of the trivalent actinide and rare earths can be developed. Additisad work remains to be done in regard to identifying ionic impurities in the actinide--rare-earth product, dewonstrating that the product is satisfactory feed for the final removi: process for americtum and curiu, st:lecting the best eluents, scallng-up the process, and recycling the prniess strtams. 


\subsection{Neptuniur Recovery}

Ca!culations were carriec out tc estimate the nuber of stages and the conditions necessary for recovering neptuniun in a Purex plant for the reprocessing of comercial LWR fuels. These calculations vere made to aid in planning laboratory experiments in which methods for maintaining the necessary concentrations of aftric and nftrous actis in the coextraction of uranius, neptunius, and plutonium and of reductants in the partitioning cycles will be studied. Calculations for equilibriu conditions were made from distributior coeffictent data and eacerial balance data. The urantun, neptuniun, and plutoniu concentrations in the aqueous feed werc assumed to be the sane as those culculated for typical LGR fuels having a bumup of 33,000 indiwetric ton.

\subsubsection{Purex process and nomenclature used}

The solvent extraction process that was studied is adification of the NFS Purex flowsheet. In this process, the urantun, neptuniun, and plutonium are first separated fron the bulk of the fission products, and the plutonium is then partitioned from the uraniu and neptunium in an Intial cycle comprised of coivans designated $\mathrm{BA}$, HB, and HC (see Table 2). The urantur and neptumiun are further purtfied (from both pluconiun and fission products) and are sepszated from each othe? in subsequent cycles in colums 1A, 1B, etc. The plutoniun is processed further in soluns designated as $2 \mathrm{~A}$ and $2 \mathrm{~B}$. The process stream are identified by both the colum and the type of strean. For examle, designations such as 1AP, 1AS, 1Ax, $1 N$, and $1 A W$ refer to the following respective streas ascociated with the In colun: feed, scrub, extractant, product, and waste.

\subsubsection{Coextraction of neptuniue, uraniun, and plutonio (BA colum)}

Seversl calculations wer: made to deterwine the approximate behavins of neptunium and other important constituente in the Hu colum as a function of key variables p.ld tl assers potential wethods and conditions for recovering neptunium as $\mathrm{Hp}(\mathrm{II})$. The purpose of the calculations was 
Table 2. Nomenclature in Purex solvent extraction at NFs:

\begin{tabular}{|c|c|c|}
\hline Gycle & $\begin{array}{l}\text { Colum } \\
\text { designation }\end{array}$ & Colum function \\
\hline \multirow[t]{3}{*}{$\begin{array}{l}\text { Uligh-activity, } \\
\text { head-end, or co- } \\
\text { decontamination }\end{array}$} & $\mathbf{H A}$ & $\begin{array}{l}\text { Coextraction of } U, P u \text {, and } N p \text {; } \\
\text { fission products, } A m \text {, and } C m \\
\text { in aqueous waste stream (HAH). }\end{array}$ \\
\hline & HP & $\begin{array}{l}\text { Partition of } \mathrm{Pu} \text { 氵rom } U \text { and } \mathrm{Np} \text {; } \\
\text { Pu stripped into an aqueous } \\
\text { product stream. }\end{array}$ \\
\hline & HC & $\begin{array}{l}\text { Stripping of } \mathrm{V} \text { and Np into } \\
\text { aqueous phate. }\end{array}$ \\
\hline \multirow[t]{3}{*}{$\begin{array}{l}\text { First uranium } \\
\text { purification }\end{array}$} & $1 \mathrm{~A}$ & $\begin{array}{l}\text { Coextraction of } U \text { and } N p ; P u \text { and } \\
\text { fission products in aqueous } \\
\text { waste. }\end{array}$ \\
\hline & 1B & $\begin{array}{l}\text { Partition of } U \text { and Np; Np } \\
\text { stripped into aqueous phase. }\end{array}$ \\
\hline & $1 C$ & U stripping. \\
\hline \multirow{2}{*}{$\begin{array}{l}\text { Secund uranium } \\
\text { pi fication }\end{array}$} & 1D & Uranium extraction. \\
\hline & IE & Uranium stripping. \\
\hline \multirow[t]{2}{*}{$\begin{array}{l}\text { Plut onfium } \\
\text { purffication }\end{array}$} & $2 A$ & $\begin{array}{l}\text { Plutonium extraction; fission } \\
\text { products in aqueous waste. }\end{array}$ \\
\hline & $2 B$ & Plutonium stripping. \\
\hline
\end{tabular}


to provide an approximate guide to the design of laboratory experiments on methods for controlling the important process variables.

The difficulties associated with oxidizing $\mathrm{Np}$ (V) to $\mathrm{Np}$ (VI) by weans of the nitrous acid-catalyzed reaction between $\mathrm{Np}(V)$ and nitric acid and then coextracting the $\mathrm{Xp}_{\mathrm{p}}$ (VI) along with the plutonium and uraniun in a Purex process were discussed in Sect. 6.5. The chief difficulty to be overcome is maintaining the neptunium as $N_{p}$ (VI) in the aqueous phase during extraction so that the desired neptunium extraction is attained in a practical number of extraction stages at the relative high extractan: loadings of uranium and plutonium. This difficulty is caused by the relatively slow oxidation rate of $\mathrm{NP}$ (IV) in the 2 to $3 \underline{M} \mathrm{HNO}_{3}$ concentration range that is dictated by the overall extraction requirements of the process. Further complications arise because the nitrous acid is highly extractable by TBP and its aqueous-phase concentration should not te allowed to $f$ all below about $10^{-5} \mathrm{M}$ during the extraction of neptunium. Also, the high loading of uranium in the TBP that is necessary for high-throughput plants lowers the neptunium distribution coefficients.

Calculations were made to estimate the following parameters involved in the coextraction of neptunium, urajium, and plutonium:

(1) The minimum number of theoretical equilibrium extraction stages necessary for coextraction of 95 to $99 \%$ of the neptunium, along with $99^{+} \%$ of the uranium and plutonium, from 2 to $3 \underline{M}$ HNO $_{3}$ solutions of LWR fuel, assuming that all the neptunium is inftially present as Np(VI).

(2) The magnitude of the depletion of the nitrous acid catalyst in the aqueous phe ie due to its extraction Into TBP during countercurrent extraction of 95 to 997 of the neptunium.

(3) The nitric acid and nitrous acid concentrations th the fuel solution that will permit sufficient oxidation during the residence time of the aqueous phase in a coextracition colum operating at practical flow rates. 
At an initial aqueous-phast feed plate concentration of 2.4 to $3.5 \mathrm{H}$ ENO,, 96 to $99+Z$ of the Ap(VI) is calculated to be extracted in three thusoretical equilibriun stages at solvent landings of uraniun and plutonlum atcained by $99+\bar{Z}$ extraction of these actinides (see Table 3 ). The nitrcus acid concentration of the aquesus phase 1 s rapdily depleted; the zelzt ive axount of depletion is about 997 after three stages. However,

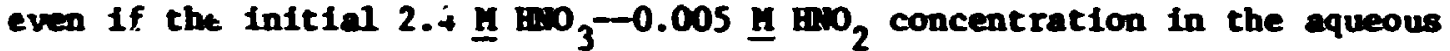
phase is aintained throughout all three stages, the time required for oxidation of the Ip(V) to Ip(VI) is too seat to be accomplished in extraction equipmeat: that operates at practical conditions and throughput rates. It would be zore practical to effect oxidation of the lpp(V) in - feed preparation atep prin: tu solvent extraction. At a feed plate concentration of $3.5 \underline{\mathrm{A}} \mathrm{BWO}_{3}-0.005 \underline{\mathrm{Y}} \mathrm{HWO}_{2}$, it may be possible to accomlish the necessary oxidation and to extract 98 to 992 of the neptuniun in pulsed coluns of dimensions used at NFS (see Table 3). A residence tine of about 22 an for the aqueous phase in the extraction saction of a 10In.-dian by 17-ft-long colum was estinated at the flow conditions given in Table 4 for operation in the organic continuous wode.

An extensive anount of development work will be needed to deternine the pernissible rasge of nitric acid and nitrous acid concestrztions and the nethod for carrying out the oxidation of neptuniu. The process that is selected wust accoplish tine necessary recovery factors for uraniun, neptuniue, and plutoniu and also achieve the necessary decontanination factors fron fission products such as zirconiun and rutheniun. Higher nitric acid concentrations inprove the neptuniun extraction but decrease the fission product decontanination; therefore, the ef fect of nitric acid concentration on overall processing requirewents will require careful evaluation.

\subsubsection{Partition:ng step (colun HB)}

In this colum, uranilu and neptuniw are separated from plutoniun by anintaining reducing conditions. Tetravalent plutonium is reduced to uextractable Pu(III), which transfers into the aqueous phase, while Ip(VI) 
Table 3. Recovery of neptunium: celculated equilibrium behevior of eome componenta in a Purex extraction at $45^{\circ} \mathrm{C}$

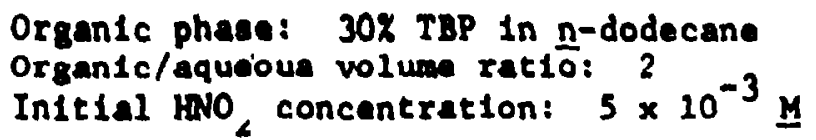

\begin{tabular}{|c|c|c|c|c|c|c|c|c|}
\hline \multirow{2}{*}{$\begin{array}{c}\text { Aqueous } \mathrm{HNO}_{3} \\
\text { feed plate } \\
\text { cor..entrattion } \\
\text { (U) }\end{array}$} & \multirow{2}{*}{$\begin{array}{l}\text { Extraction } \\
\text { orage }\end{array}$} & \multicolumn{2}{|c|}{ Component } & \multicolumn{2}{|c|}{$x$ axtracted! } & \multicolumn{2}{|c|}{$\begin{array}{l}\text { Equilibrium aqueoue-phase } \\
\text { composition }\end{array}$} & \multirow[b]{2}{*}{$t_{1 / 2}(m 1 n)^{b}$} \\
\hline & & $N p$ & v & $\mathrm{Pu}$ & $\frac{1}{2 x}$ & $\mathrm{HNO}_{3}$ (M); & $\mathrm{HWO}_{2}\left(\underline{M} \times 10^{4}\right)$ & \\
\hline 2.4 & $\begin{array}{l}1 \\
2 \\
3\end{array}$ & $\begin{array}{l}37 \\
75 \\
96\end{array}$ & $\begin{array}{l}88 \\
99+ \\
99+\end{array}$ & $\begin{array}{l}28 \\
99+ \\
99+\end{array}$ & $\begin{array}{l}9 \\
- \\
-\end{array}$ & $\begin{array}{l}2.0 \\
1.9 \\
1.8\end{array}$ & $\begin{array}{l}8.0 \\
0.5 \\
0.03\end{array}$ & $\begin{array}{l}16 \\
20 \\
21\end{array}$ \\
\hline 3.5 & $\begin{array}{l}1 \\
2 \\
3\end{array}$ & $\begin{array}{l}60 \\
96 \\
99+\end{array}$ & $\begin{array}{l}88 \\
99+ \\
99+\end{array}$ & $\begin{array}{l}88 \\
99+ \\
99+\end{array}$ & $\begin{array}{c}12.0 \\
=\end{array}$ & $\begin{array}{l}3.0 \\
2.8 \\
2.8\end{array}$ & $\begin{array}{l}9.0 \\
1.0 \\
0.09\end{array}$ & $\begin{array}{r}4.1 \\
5.0 \\
>5.0\end{array}$ \\
\hline
\end{tabular}

Inttial concentratione of neptuntum, urantum, and plutonium were $0.135,171.5$, and 1.63 g/ilter, reapectively.

b Tiwe requited to oxidize $50 x$ of the $\mathrm{Np}(V)$ t.o $\mathrm{Np}(\mathrm{VI})$ at the equilibrium aqueous-phase concentratione of $\mathrm{HWO}_{3}$ and $\mathrm{WNO}_{2}$ Indicated. At the Intelal concentration, the $t_{1 / 2}$ valuen for 2.4 and $3.5 \mathrm{H}^{\mathrm{HNO}} \mathrm{H}_{3}$ are 9.0 and $2.5 \mathrm{~min}$, respectively. 
Table 4. Calculated crmposition's of atreams exiting the coextraction and acrubbing column. Compositions based on three extraction and two scrubbing stages and organfc-phase cont Inuous operation

\begin{tabular}{|c|c|c|c|c|c|c|c|c|}
\hline \multirow[b]{3}{*}{ Stream } & \multirow{3}{*}{$\begin{array}{c}\text { Volume } \\
\text { (11ters/hr) }\end{array}$} & \multirow{3}{*}{$\begin{array}{l}\mathrm{HNO}_{3} \\
(\underline{\mu})\end{array}$} & \multirow{3}{*}{$\begin{array}{l}\mathrm{HNO}_{2} \\
(\underline{M})^{2}\end{array}$} & \multicolumn{5}{|c|}{ Metal content } \\
\hline & & & & & & $-\mathrm{N}$ & & \\
\hline & & & & U & Pu & Case A & Case B & $2 r$ \\
\hline $\begin{array}{l}\text { Organic } \\
\text { product } \\
\text { (HAP) }\end{array}$ & 464 & 0.22 & 0.3024 & $83.3 \mathrm{~g} / 11$ ter & $0.79 \mathrm{~g} / 11$ ter & $0.045 \mathrm{~g} / 11 \mathrm{ter}$ & $0.045 \mathrm{~g} /$ 11ter & $1.2 x^{t}$ \\
\hline $\begin{array}{l}\text { Aqueous } \\
\text { raf finate } \\
\text { (HAW) }\end{array}$ & $24 i$ & 3.06 & 0.00011 & $0.02 \%$ & $0.08 \%$ & $1.27 x$ & $0.14 x$ & - \\
\hline
\end{tabular}

an Case $A, 100 \%$, of the neptuntum was assumed to enter the $H A$ column as $\mathrm{Np}(V)$ : in Case $B$, it was assumed to be $100 x \mathrm{~Np}$ (VI).

benotes percentag': of total in that phase. 
is reduced to Np(IV), which is also extractable and thus remains in the organic phase along with the $U(V I)$. Calculations are being carried out to deternine the approxieate concentration of U(IV)nitrate-hydrazine that will be required for experiments in which alternative reductants for the partitioning of plutonium from uranium and plutoniun will be studied.

Thus far, one calculation has been ade for an awount of $U$ (IV) reductant that was satisfactory for partitioning greater than 997 of the plutonium from greater than 997 of the uranium (Table 5). Partitioning conditions were chosen so that the nitric acid concentration in the aqueous phase was maintained between 1.5 and $1.75 \mathrm{M}$ in all extraction stages. Aqueous-phase concentrations of nitric acid which exceed $2 \underline{y}$ in any extraction stage were considered undesirable because of possible reoxidation of the Pu(III) to Pu(IV), which would lower the separation factor for ura.iium and plutonium.

The reduction conditions exployed were not sufficient to keep all of the neptunium in the organic-phase product ( $\mathrm{HCU}$ ) with the uranium; about 867 was present in the uranium product (HCU), and about $14 \%$ in the plutoniu product (HBP). Although the calculations of the neptuniu separation are only approximate, they tend to give further support to the feasibility of U(IV) as a reductant for partitioning piutonium from uranium and neptunfum. The U(IV) concentration was estimated on the basis of the requiresents for reduction of Pu(IV) to Pu(III), but the neptunium behavi of in olutonium partitioning was based on neptunium distribution coefficients that were ojtained with an initial reductant concentration of $0.61 \underline{M} U$ (IV)--0.1 $\underline{M}$ $\mathrm{N}_{2} \mathrm{H}_{4}$. These coefficients are prubably low since a higher U(IV) concentration was euployed in the evaluation of the composition and contents of the product streams. However, a literature search shoved tha: these were the only coefficient values that were applicable to our calculations, and our purpose in the neptunium calculations was to evaluate the magnitude of the neptunium recovery problem. It is believed that the calculated value for the quantity of neptunium in the uranium product is conservative. This subject, along with the process control difficulties that are expected with the use of U(IV) as a reductant in partitioning, is discussed further in Sect. 7.2.5. 
Tablo 3. Calculated otrean compostione for particion colum Ho

Section $\mathrm{HXX}_{1} 6$ theoretical atague

Section HSS: \& theoret1cal atanes

Telperature: ${ }^{4} 43^{\circ} \mathrm{C}$

\begin{tabular}{|c|c|c|c|c|c|c|c|}
\hline & \multicolumn{7}{|c|}{ Streen } \\
\hline & $\begin{array}{l}\text { (Hows } \\
\text { (HAP) }\end{array}$ & $\begin{array}{l}\text { Pu otrip } \\
\text { (HaX) }\end{array}$ & $\begin{array}{l}\text { Scrub } \\
\text { (Has) }\end{array}$ & $\begin{array}{l}\text { Difwant } \\
\text { (Has) }\end{array}$ & Roductent & $\begin{array}{l}\text { U-Np ploduce } \\
\text { (HCU) }\end{array}$ & $\begin{array}{l}\text { Plutont } \\
\text { (HAP) product }\end{array}$ \\
\hline stage & 6 & 1 & 10 & 6 & 7 & 1 & 10 \\
\hline Phase & $30 x$ TUP--NPH & Aquous & $30 x$ TAP--NPH & 302 TAP--NPH & Aqueoue & $30 X$ TJP--NPK & Aqueous \\
\hline Flow, l1tere/hr & 464 & 74 & 135 & 241 & 16 & 740 & 90 \\
\hline $\mathrm{HNO}_{3} \cdot \underline{M}$ & $0 .-2$ & 1.72 & 0.3 & - & 1.0 & 0.193 & 1.56 \\
\hline$N_{p},{ }^{b} x$ & 100 & - & - & - & - & 86 & 14 \\
\hline $\mathrm{Pu}^{\mathrm{b}} \mathrm{x}$ & 100 & - & - & - & - & $<0.2$ & $99+$ \\
\hline$u(v 1), x$ & 100 & - & - & - & - & $>99$ & 0.001 \\
\hline$U(I V), C \underline{ }$ & - & - & - & - & $0.5^{d}$ & 0.01 & 0.01 \\
\hline $\mathrm{N}_{2} \mathrm{H}_{6}={ }^{\mathrm{C}} \underline{\mathrm{H}}$ & - & 0.2 & - & - & 0.2 & - & 0.2 \\
\hline $\mathrm{NO}_{2}^{-} \cdot \mathrm{M}$ & 0.0022 & - & - & - & $\therefore$ & - & - \\
\hline
\end{tabular}

stage number where etrean entere or leaves the colum.

bPercentages are baeed on the asounte of neptunilum and plutonium in the feed otreas (HAP).

CChaveal raectione in the colum are not taken into account.

${ } U$ (IV) concentration to based on requtremente for the raduction of PU(IV) to Pu(III). 


\subsubsection{First uraniue purification cycle}

Uranium and neptuniun are stripped from the organic effluent of the

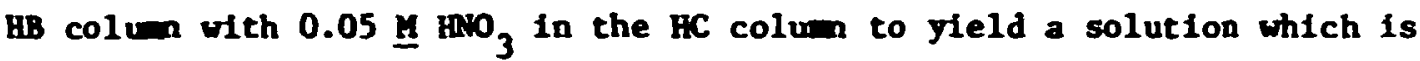
$0.11 \underline{M}$ in $\mathrm{V}(\mathrm{VI}), 0.15 \underline{M}^{\text {In }} \mathrm{HWO}_{3}$, and contains 862 of the neptunium in the HB colun feed plus traces of plutonium. The solution is concentrated by

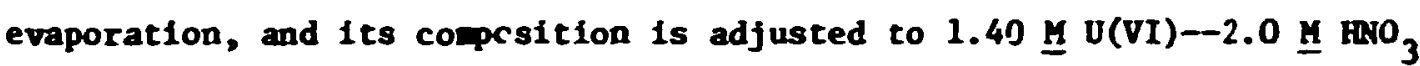
in order to prepare the aqueous feed (IAF) for the first uranium purification cycle.

Colum 1A. In this colum, the uranium and neptunium are again partitioned from the last traces of plutoniu by maintaining reducing conditions in the colum with $\mathrm{U}(\mathrm{IV})-\mathrm{N}_{2} \mathrm{H}_{4}$. The calculated strean compositions, given in Table 6, show that the aqueous raffinate should contain essentially all of the realining plutonium ( $99+7$ of the trace amount in the feed stream to this colum), less than $0 . n 12$ uraniu, and about $38 z$ of the neptunium in the feed to this coluen. The poor neptunium recovery is discussed in Sect. 7.2.5.

Coluns 1B and IC. In colven 1B, uranium and neptunium are separated by maintaining a high $U(V I)$ concentration (0.21 $M$ ) in the organic phase and a low actdity $\left(0.5 \underline{\mathrm{M}} \mathrm{kr} \mathrm{O}_{3}\right)$ in the aqueous phase, so that $\mathrm{Np}$ (IV) 18 forced into the aqueous phase. The calculations show that $99+7$ of the neptunium in the IAP feed will report to the neptuniue product streas, as will about 0.22 of the uranium, which is readily separable in any subsequent neptunium purification cycle. In colum $1 C$, the uranium is stripped fros the organic phase with $0.05 \underline{M}_{\text {HWO }}$ to yield a product solution that $180.125 \underline{\mathrm{M}}$ in U(VI). The results of calculations for these two coluns are contained in Table 7.

\subsubsection{U(IV) $-\mathrm{H}_{2} \mathrm{H}_{4}$ as a reductant for neptuniue}

The substitution of $\mathrm{U}$ (IV) $-\mathrm{H}_{2} \mathrm{H}_{4}$ for $\mathrm{Pe}\left(\mathrm{NH}_{2} \mathrm{SO}_{3}\right)_{2}$ is complicated, not only because the kinetics of neptunium redustion is slower but also because an appreclable quantity of $U$ (IV) way be extracted under certain conditions. The neptuniun distribution coeffictents, $D_{\mathrm{a}}^{\circ}[\mathrm{Np}(\mathrm{IV})]$, used in the calculations 
Table 6. Calculated stream compositiona for colum 1A

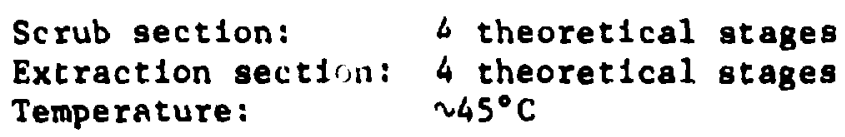

\begin{tabular}{|c|c|c|c|c|c|}
\hline & \multicolumn{5}{|c|}{ Stream } \\
\hline & $\begin{array}{l}\text { Feed } \\
\text { (1AF) }\end{array}$ & $\begin{array}{l}\text { Scrub } \\
\text { (1AS) }\end{array}$ & $\begin{array}{c}\text { Extractant } \\
(1 \mathrm{AX})\end{array}$ & $\begin{array}{l}\text { Overhead } \\
\text { (1AP) }\end{array}$ & $\begin{array}{c}\text { Raffinate } \\
\text { (IAW) }\end{array}$ \\
\hline Stage ${ }^{a}$ & 5 & 1 & 8 & 1 & 8 \\
\hline Phase & Aquesus & Aqueous & $30 \%$ TBP--NPH & $30 \%$ TBP-NPH & Aqueous \\
\hline Flow, liters/hr & 98 & 67 & 335 & 335 & 165 \\
\hline $\mathrm{SNO}_{3}, \mathrm{M}$ & 2.0 & 2.0 & - & 0.005 & 2.0 \\
\hline$N_{p}, b \%$ & 100 & - & - & 62.5 & 37.5 \\
\hline Pu, & 100 & - & - & $<0.1$ & $=99$ \\
\hline$u(V I), b x$ & 100 & - & - & $>99$ & $<0.01$ \\
\hline$U(I V), C \underline{M}$ & 0.01 & - & - & 0.0021 & 0.0015 \\
\hline $\mathrm{N}_{2} \mathrm{H}_{4}, \mathrm{C} \underline{\mathrm{M}}$ & 0.1 & 0.1 & - & - & 0.1 \\
\hline
\end{tabular}

${ }^{\text {a }}$ Stage number where stream enters or leaves column.

bercentages are baset on the amounts of neptunium, plutonium, and urantum in the feed stream (1AF).

${ }^{c}$ Chemical reactions in column are not taken into account. 
Table 7. Calculated etream compestitione for colunne la and $1 \mathrm{C}$

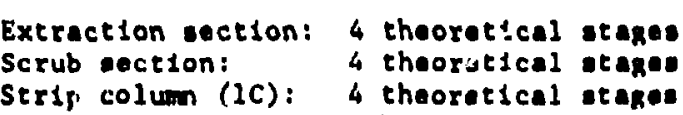

4 theoretscel atages

Temperature: Ambient

\begin{tabular}{|c|c|c|c|c|c|c|c|}
\hline & & & & Stream & & & \\
\hline & $\begin{array}{l}\overline{\text { Peed }} \\
(1 \text { AP) }\end{array}$ & $\begin{array}{l}\text { Scrub } \\
\text { (1DS) }\end{array}$ & $\begin{array}{l}\text { Extractant } \\
\text { (1BX) }\end{array}$ & $\begin{array}{l}\text { Overhanel } \\
\text { (IBU) }\end{array}$ & $\begin{array}{l}\text { Np product } \\
\text { (1BP) }\end{array}$ & $\begin{array}{c}\text { Spant organtc } \\
\text { (1CW) }\end{array}$ & $\begin{array}{l}\text { Uproduct } \\
\text { (ICU) }\end{array}$ \\
\hline Stage" & 5 & 1 & 8 & 1 & 8 & 4 & 1 \\
\hline Phase & $30 \times: A P--N F H$ & Aqueous & $30 X$ TDP--NPH & 30X TBP--NPH & Aq jeou: & $30 \%$ TAP--NPH & Aquanue \\
\hline Flow, litera/hr & 335 & 85 & 104 & 439 & BS & 439 & 1097 \\
\hline$v(V I), \underline{M}$ & 0.41 & - & - & 0.31 & 0.0038 & - & 0.125 \\
\hline $\operatorname{hitc}_{3}, \underline{\underline{A}}$ & 0.005 & 0.5 & - & $<0.01$ & 0.52 & $\cdot$ & 0.05 \\
\hline$x_{p}=x$ & 100 & - & - & $<0.1$ & $99+$ & - & $<0.1$ \\
\hline
\end{tabular}

stage number where atroam entere or leavea colum.

bercentages are based upon the anount of noptuntum in the foed streas (1AP) to colum 18. 
for coluns BB and la were derived from results on work in which 302 TSP-RPB loaded with varying U(VI) concentrations and contalning $5 \times$ $10^{-4}$ I up(VI) was equilibrated for 15 win with aveous acid solutions containing $0.01 \underline{\mathrm{H}} \mathrm{U}(\mathrm{IV})-0.1 \mathrm{M}_{2} \mathrm{H}_{4}$ as the reductant. ${ }^{40}$ For constant acid concentratins, the neptunive distribution coefficient was a madman viven the crgalc phaie was sbout 302 saturated with urmilu [ 0.16 I in $\mathrm{O}(\mathrm{VI})]$. The neptuniu distribution coefficient increased vinis acidity for constant organic $C$ (VI) loeding; it also increased with Ini reasing temprature. Sinflar $D_{a}^{0}$ data, which were obtained with $\mathrm{Fe}\left(\mathrm{aH}_{2} \mathrm{SO}_{3}\right)_{2}$ as the reductant, showed a steady in irease in neptunito distribution coefficiests with decresting $V(V I)$ loading in the organic phase. A contributing cause for this difference (in addition to slower kinetics) ay be the extrictabliticy of U(IV). As loadiags decrease in the organic ptase, the nestuniu distribution coefficient wa be expected to increase; hovever, in this case, the extracion of 0 (IV) would al so increase and, since the leduction of " (V) to Mp(IV) occurs in the aqueous phase, the lower aqueo is U(I. -oncentration might affect the reduction rate and thus, result in lower $D_{a}^{0}[\mathrm{LP}$ (VI)]. Nlchough the experimental conditions appear to be a sood approxdmation to colum operation, the results :alculated with these $D_{a}^{0}[$ IIp (IV)] are probably pessidstic due to the low initial U(IV) concentration.

In the separations carried out in coluns in and $1 \mathrm{~h}$, the highest concentration of $U(I V)$ in the aqueous phase occurs in tive upper extraction stages, whereis tise lowest U(IV) concentrations in the aqueous phase occur in the 10:=r extractics stages. These concentration differences are the result of $U(I V)$ extractability in the organic phase. Even though the extractabilicy of U(IV) is reduced by mintaining the highest U(VI) concentrations of the organic phase in the upper extraction stages, it is st111 suffictently high to deplete the V(IV) concentration in the lower extraction stages. Thus, Mp (VI) entering the colum in the organic phase is reduced rapidly to the poorly extractable Np(v), which afgrates down the colun where the probability of further reduction 18 diainished by the low aqueous $U(I V)$ concentracion. It 1 e evident that care wust be exercised to ensure that an adequate $U$ (IV) concentration is present where it is

"NPH = noraul paraffin hydrocarbo". 
required in the colum. The loss calculited for the $1 \mathrm{~A}$ colum is associated with the questionable values of $D^{0}[\mathrm{ND}(\mathrm{IV})]$ used in the calculations. Results of a test at the hanford plant ${ }^{36^{a}}$ ir which $\mathrm{U}(\mathrm{IV})-\mathrm{N}_{2} \mathrm{H}_{4}$ was substituted

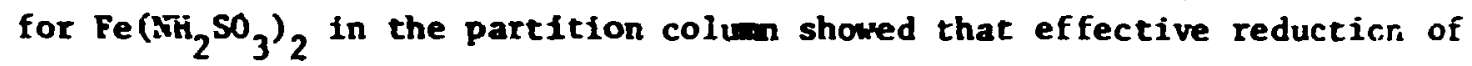
plutoniu was achieved without increasing the neptunfum concentration in the plutonium product. This suggests that $U\left(\right.$ IV) $-\mathrm{N}_{2} \mathrm{H}_{4}$, when properly used, would also be an effective reductant for neptunium.

8. CONCEPTUNL FLOUSHEET STUdIES ON RECYCLE IN THE PUREX FROCESS

Conceptual waterial-balance flowsheets for the recycle of nitric acid and actinide-bearing streams in a Purex process were evaluated in con-

- siderable detail with regard to main-line fuel reprocessing and exhaustive extraction. The purpose of the flowsheet studies is to aid in the visualization of plant wodifications which will endble exfective integration of a primary reprocessing plant with a waste processing plant (Fig - 10). The flowsheets are based largely on operating experience at NFS. Material balance flowsheets for the recycle of nitric acid and actinides are shown in Figs. 11 and 12. The material balances are based on fuel irradiated to a burnup of $33,000 \mathrm{Mwd} /$ metric ton. Details of the material balances throughout the many processing steps are shown in Figs. 13 and 14. The nomenclature used in designating equipment in these flowsheets is the same as that described in Sect. 7.2.1.

In order to prevent losses of uranium, neptunium, and plutonim to waste streams from the partitioning and purification processes, these streams must be recycled to the first extraction colum in which all three ac"-inides are coextracted (FIgs. il and 12). This can be accomplished by an evaporation-distillation process in which the streams are collcentrated by evaporation and further distillation (Fig. 15). The overheads from evaporation are combined with other nitrate recovery streams (including $\mathrm{NO}_{x}$ absorption) and processed through a $\mathrm{HNO}_{3}$ recovery tower. The recovered nitric acid is then recycled to previous stages in the processing, and the actinide concentrate is recycled to the coextraction column (HA) via the dissolver. 
ORNi DWO 74-7494

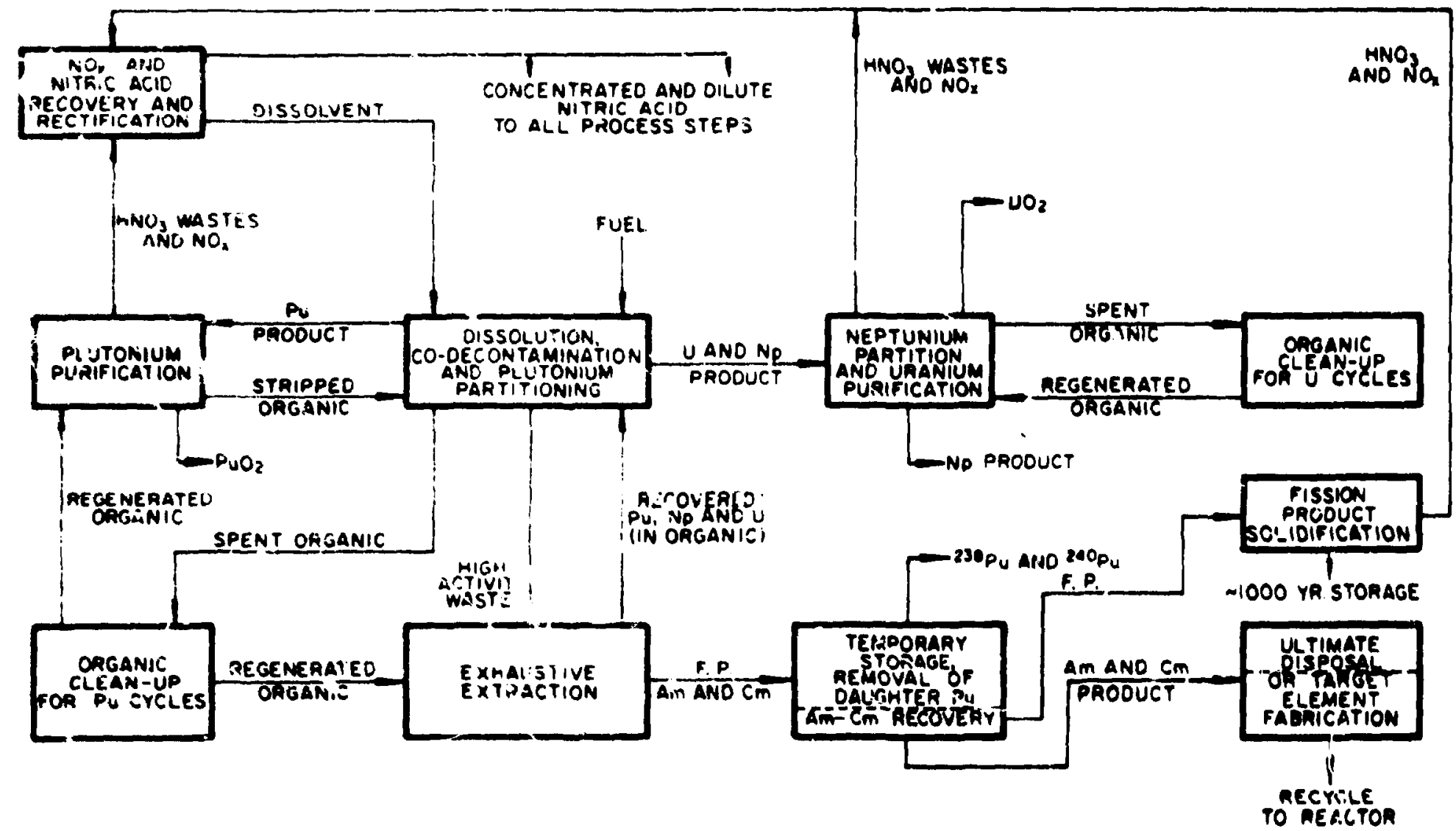

F1g. 10. Conceptual flowsheet for solvent extrantion processing of 1rradiated LWR Euel with wiste partiticning and recycle of heavy-metal and nitric acid valies. 


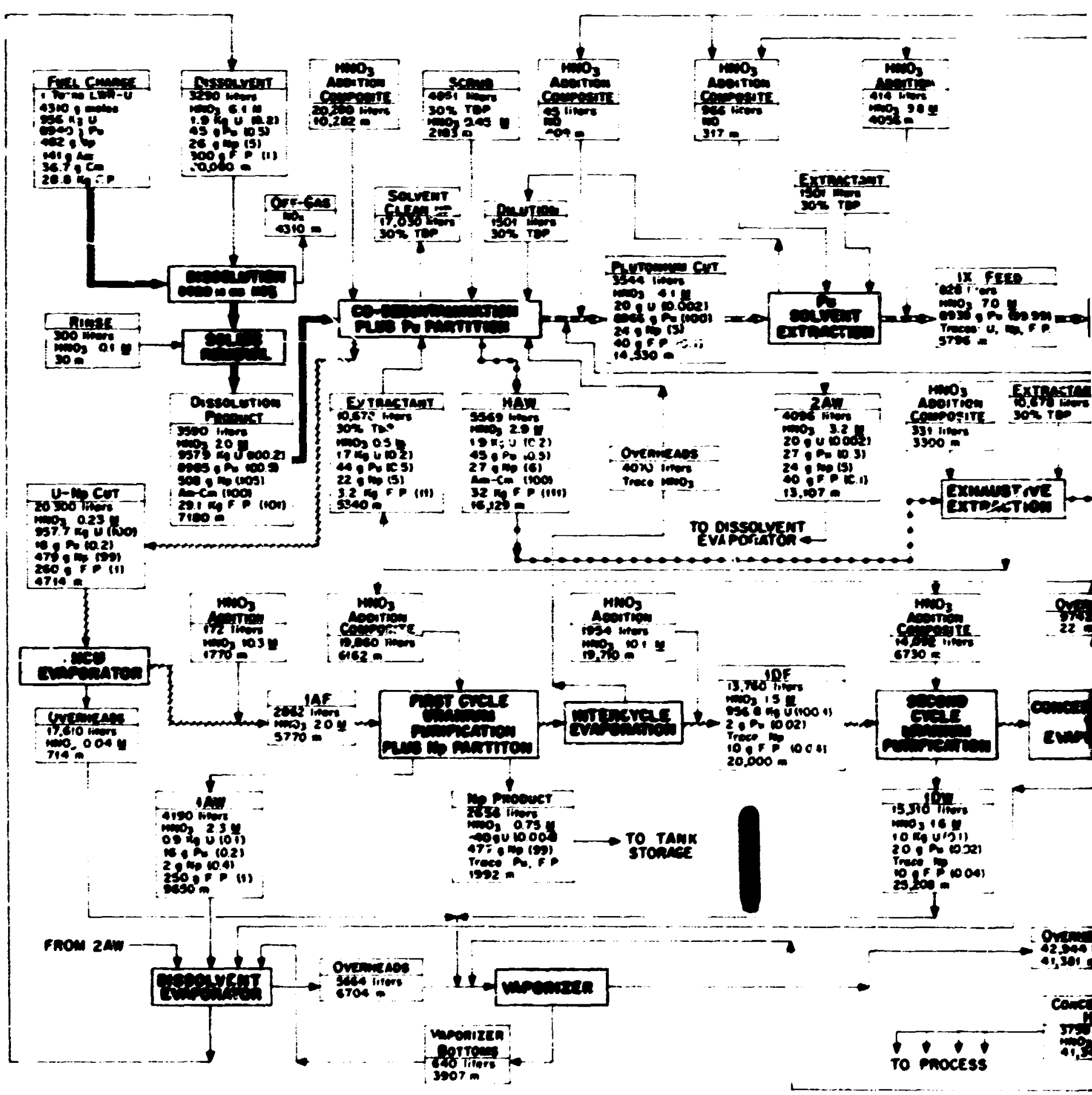

F18. 11. Conceptial flowsheet for colvent extractic Irradiated PWR-U fuel including waste partitioning, shmo recycle schemes and typical material balances for heavy acid values. 


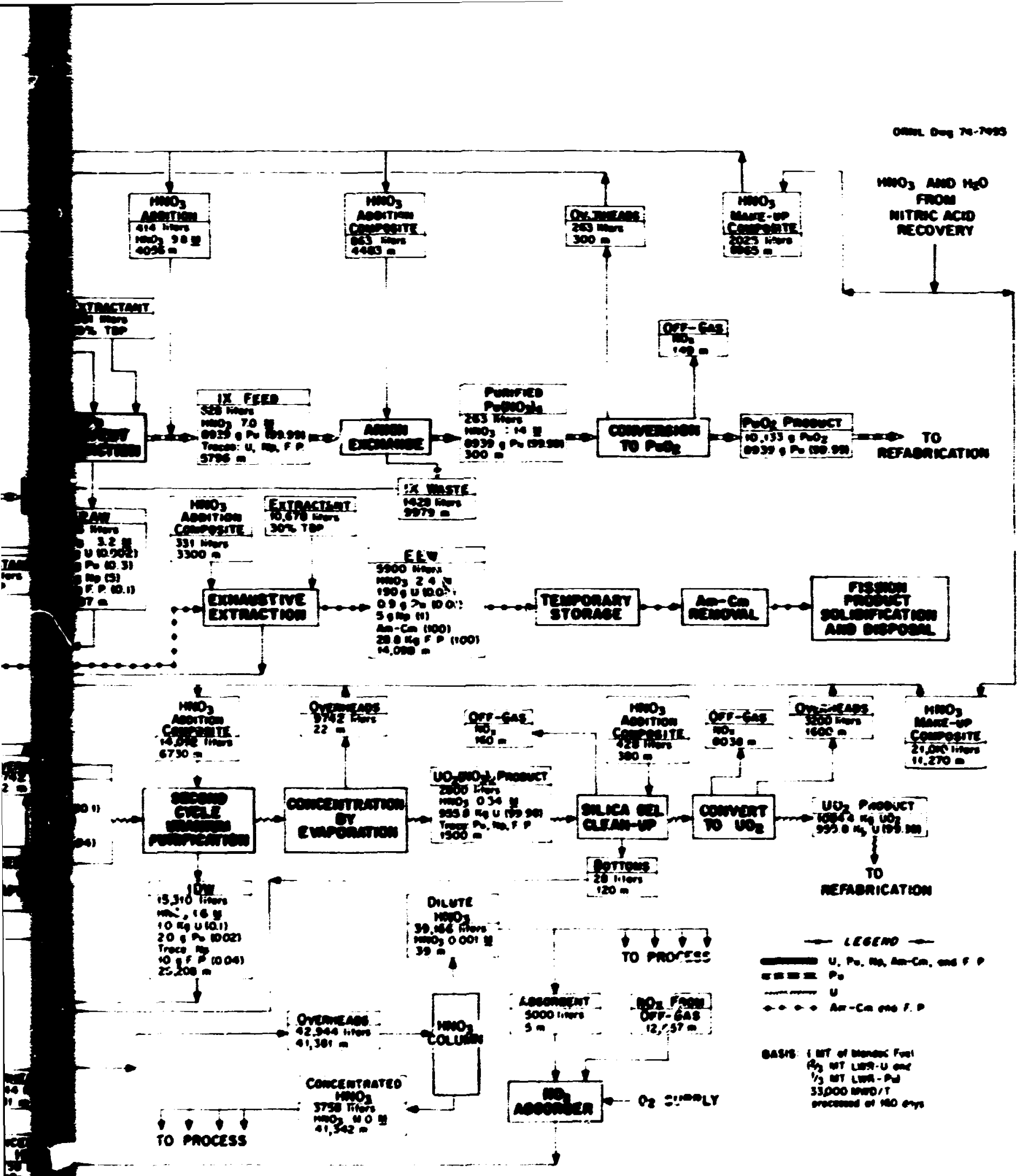

wet for colvent extraction processing of

waste partitioning, ehcwing proposed

rial balances for heavy ratals and nitric

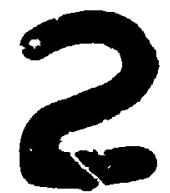




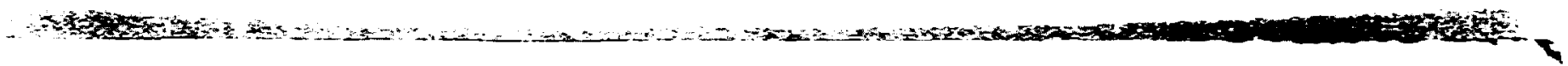

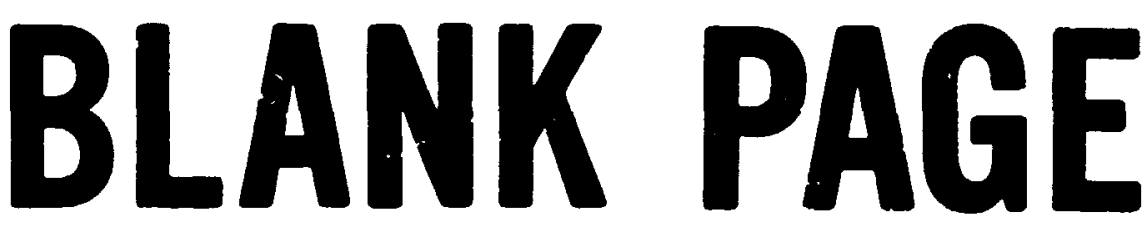




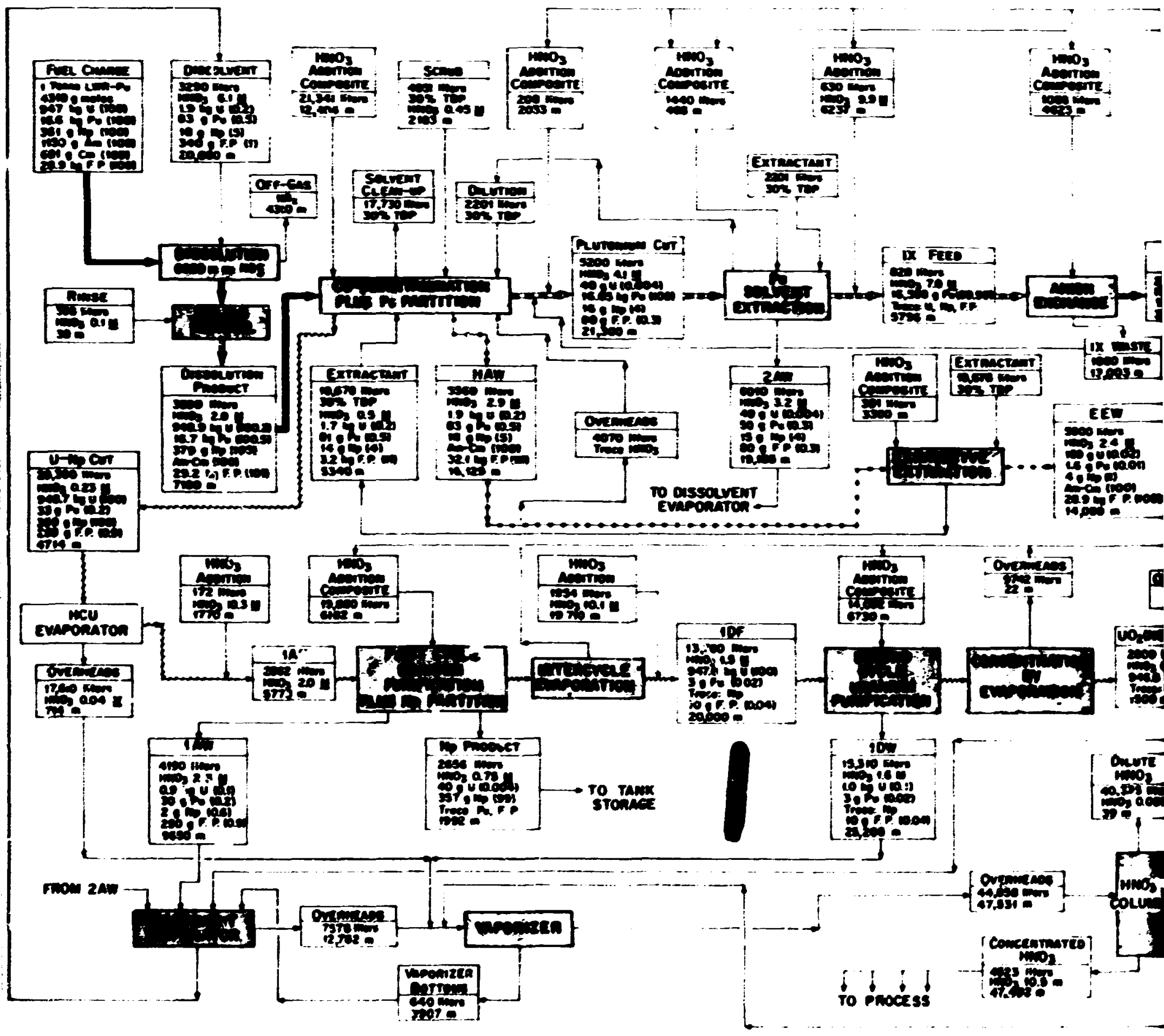

P18. 12. Concaptual flowhect for solvent extraction 1r radiated Frh-Pu fuel Including vaete partiticalng, ehouta respcle schenes and typical anterial balances for heary me ac1d values. 


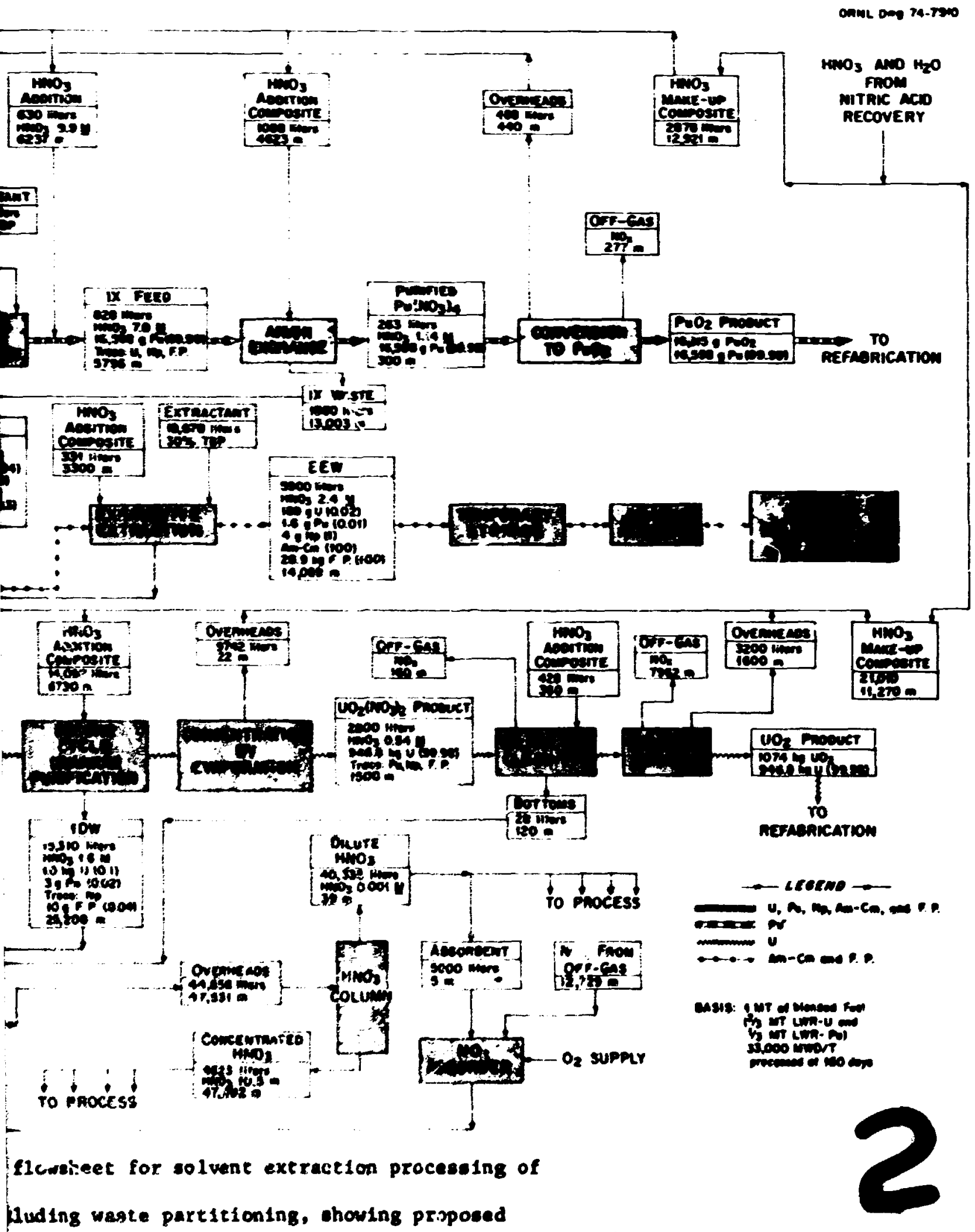

II anterlal bolances for heavy wotals and nitric 


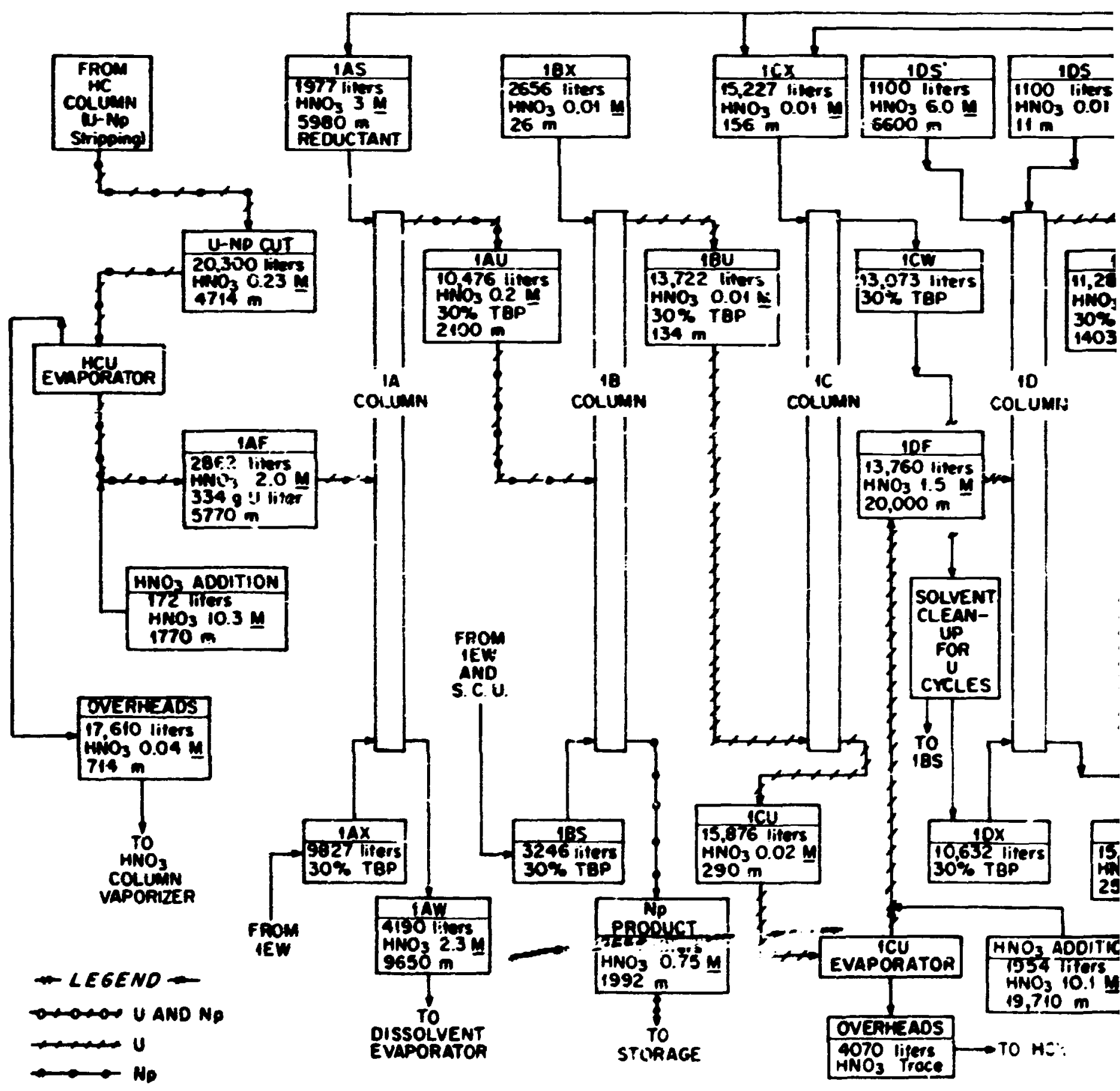

F1g. 13. Detalled nitric acid balance 1 and urantum purification. 


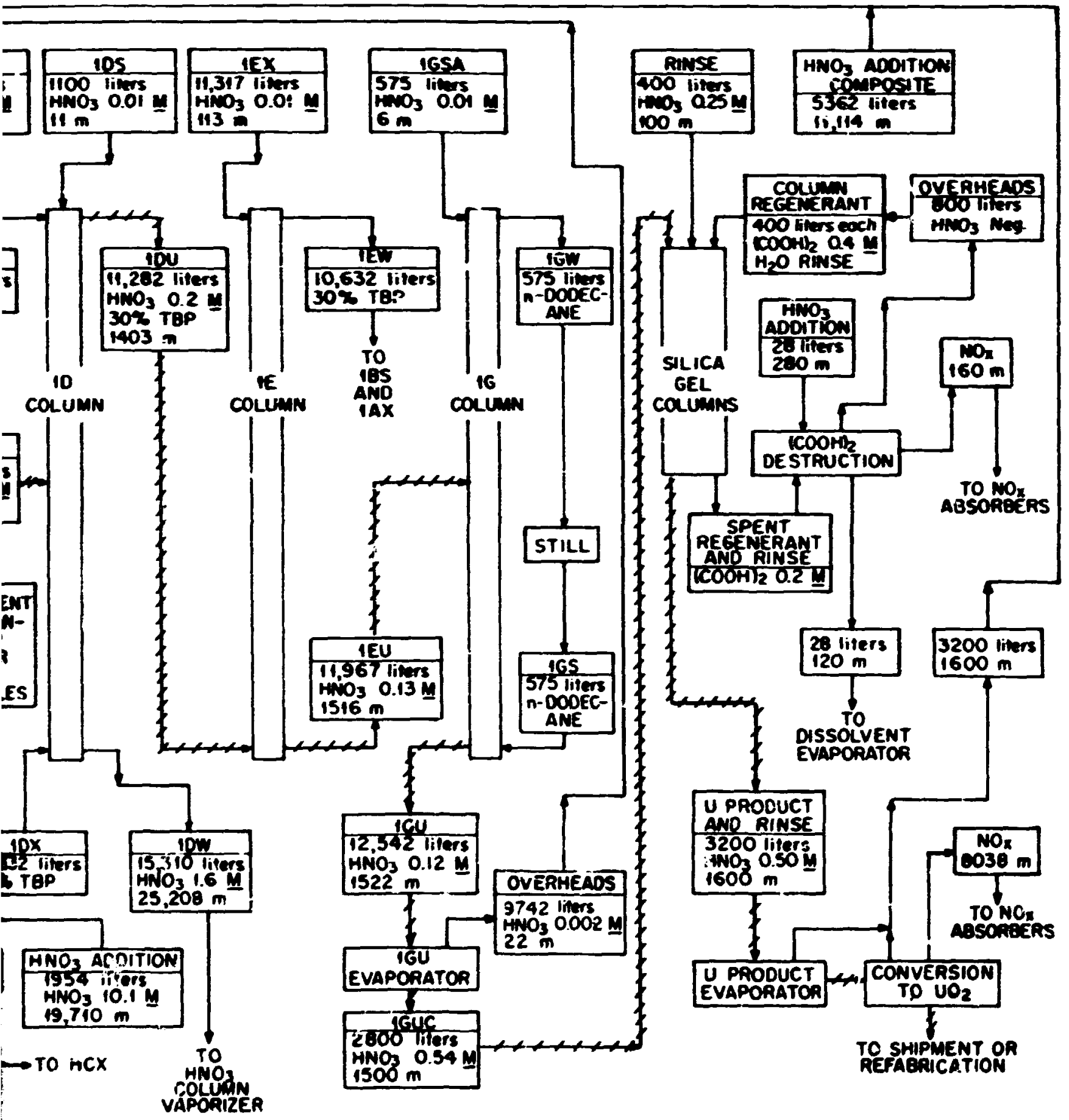

cld balance in neptuntum partitioning

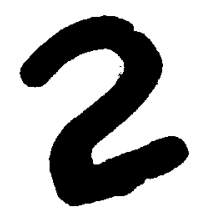




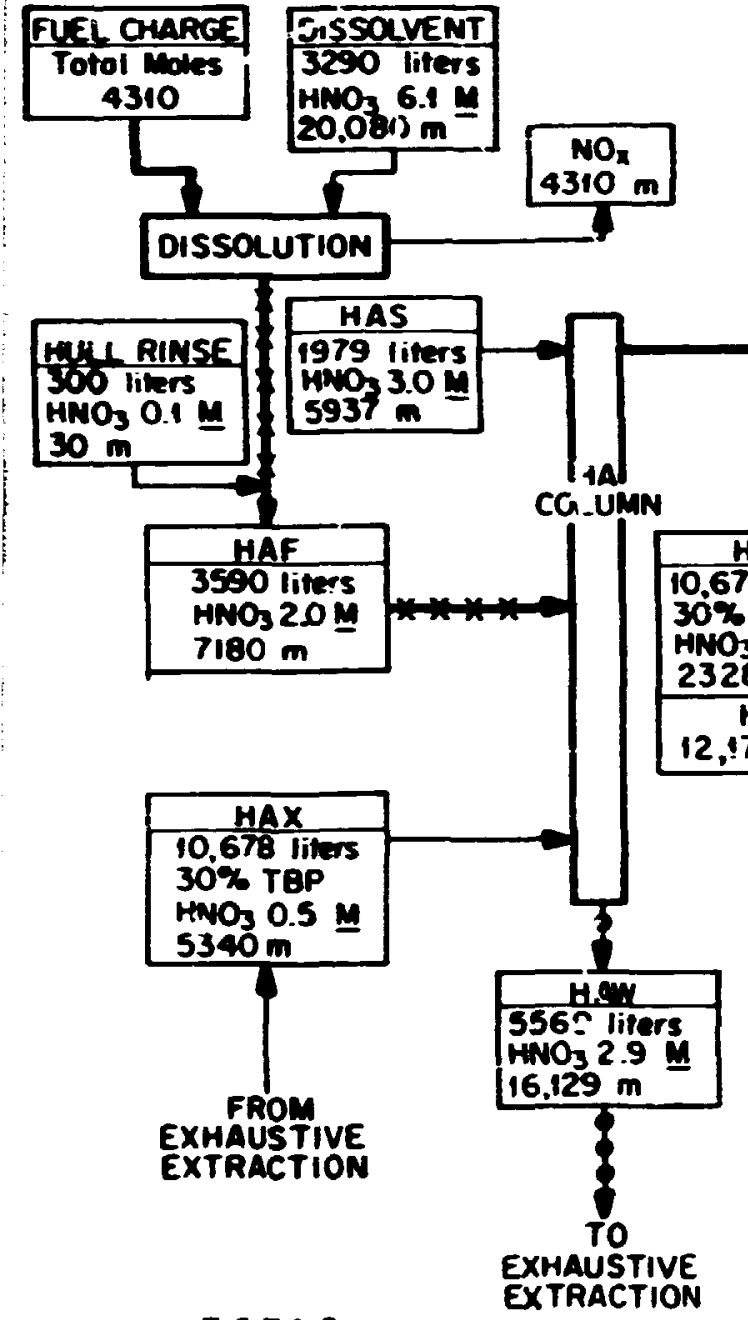

$-\angle E G E N D \rightarrow$

* U, Pu, No, Am, Cm, F. P.

U. Pu, No

Am, Cm, F. P.

U, No

$\longrightarrow P_{\mathrm{S}}$

S.C.U. SOLVENT CLEAN UP

FROM HCU

EVAPORATOR

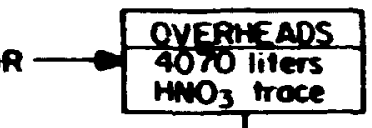

Hax

$\$ 703$ liters

$\mathrm{HNO}_{3} 2.0 \mathrm{~m}$

$3406 \mathrm{~m}$

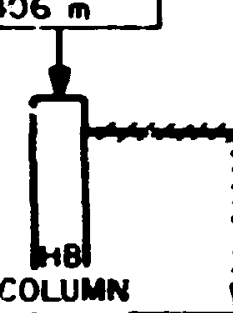

HAP 10.678 liters $30 \%$ TBP

$\mathrm{NNO}_{3} 022 \mathrm{M}$

$\mathrm{HBF}$

12,!79 liters, 


\section{BLANK PAGE}

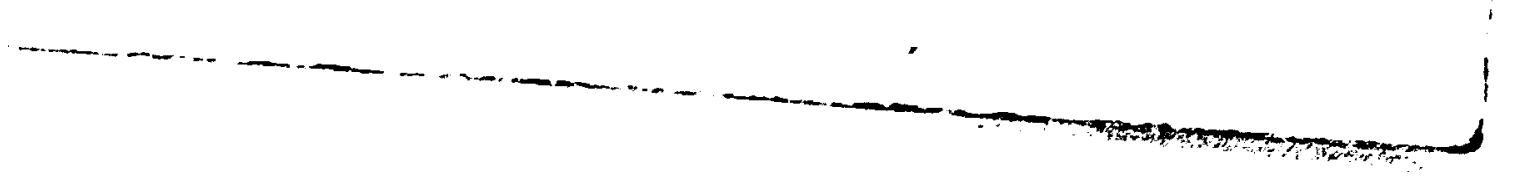




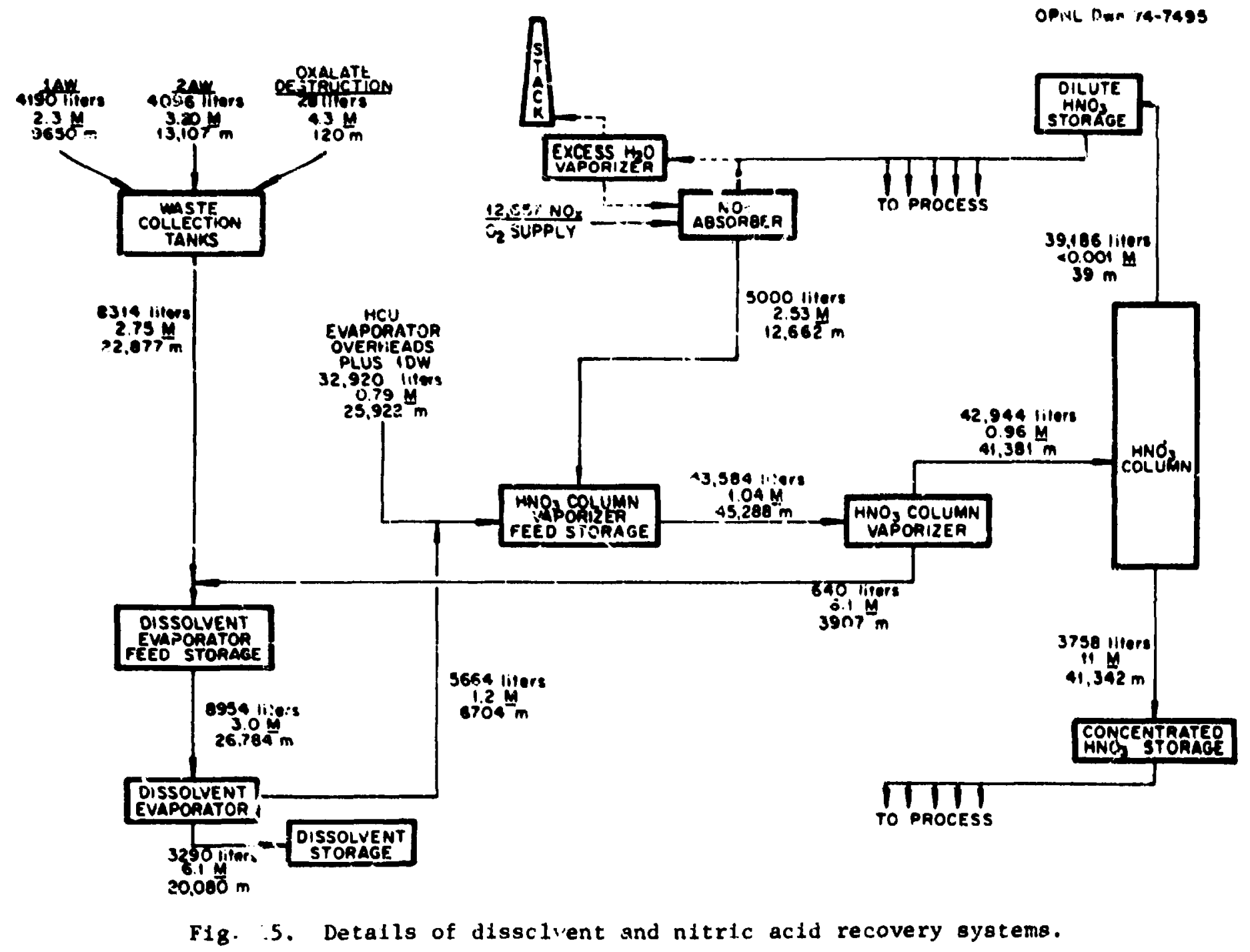


The necessity of recycle restricts the choice of reductants used in plutonita partitioning and possibly if other process chenicals as well. In our reference flowsheet, we have chosen $U$ (IV)- $N_{2} n_{4}$ rather than ferrous sulfanate as the reductant for plutoniun. Although material balmces for this reagent have not been completed, it now appears that effective recycle can be accomplished if a reductant such as $U$ (IV) $-\mathrm{H}_{2} \mathrm{H}_{4}$ is suj cable and if adequate fission product decontanination can be anintained when all of the nitric acid is recycled. Experimental studies will need to be carried out to deternine the suitability of varlous altemative reduction ethods for plutonion and the effect of conplete nitric acid recycle ou fission product decontanination. Also, it is ipportant to know what ifpurities are generated by radiation danage to the solvent, since ihey ay ultinately appear in the aqueois waste streas in significant concentrations and cause coiplications during prolonged recycle of the waste streans.

\section{SURMARY}

The percentage removals of actinides and ${ }^{129}$ I from spent fuels that will reduce the potential hazard values of comercial high-level waste at 1000 years to values comparable to uranium minerals have been determined, ind tire feasibility of various processes for accomplishing these rewovais is be ing studied. Rewoval of $99.99 \%$ of :he plutonium, 99.92 of the uraniun, anericiux, curium, and ${ }^{129} I$, and $95 \%$ of the neptuniun from LWR fuel (with plutorium recycle) decreases the hazard value of high-level waste ai 1000 years to about $5 \%$ of the value for pitchb!ende. Removal of actinides and ${ }^{129}$ I from LWR fuels to this extent appears to be a desirable goal to attain before consideration of further treatment. Such a goal is necessary because the actinides are the major contributors to the potential hazard of high-level waste and rewoving them w11 require removal factors 10 to 100 tines greater than those reported for actinides in processing facilities at iadiation levels comparable to that from high-level waste. At the aforerienticned rewoval percentages, ${ }^{99} \mathrm{TC}$ and the residial plutonium and amert.cium contribute about equaily to the hazard of high-level waste from LWP fuels in which the plutonium is recycled. Further removal of the a. inides does not appear to be warranted unless ${ }^{99}$ Tc is also removed. Of course, other 
combinations of calculated percenteges of removal will also reduce the potentic! waste hozard to about $5 \pi$ of that for pitchblende, and further refinements in the percentages an be necessary as the progran progresses.

Results of studies ade thus far indicate that the oost pronising concept for achieving the desired remvals of artinides from LIR fuels includes both improved recovery of the actinides in conventional fuel reprocessing and secondary processing of the high-level waste. Conceptual flousheet studies of separations processes that are potentially applicable to this renoval concept have revealed a nuber of difficult problen that wil have to be solved before satisfactory processes can be developed art, In turn, integrated inco a functional waste processing facility at the expected levels of radioactivi:y. The most iffortant of these appear to be:

(1) Increasing the recovery of plutoniun to the desired levels.

(2) Development of a satisfactory anericiu and curiu process.

(3) Devising wethods for avolding actinide losses to insoluble residues fron fuel dissolution and to solids that are generated in the subsequeat processes.

(4) Adequate recycling of streans generated in the processing.

It appears that the necessary renovai of uraniun and neptuniun can probably be accoplished by modifications and additions to the currently used Purex process. Satisfactory recycle of process chenicals can probably be developed for conceptual processes in which improved recoveries of uraniun, neptuniun, and plutoniua are achieved in a Purex process. A substantial research and development effort is needed to deternine whether the recycle problens associated ainly with the secundary processing for anericium and curiug can be solved.

Laboratory studies of separations wethods that appear wot pronising are under way, and results from these studies are reported. Severa?. candidate processes of potential applicablitty have been reviened, and conceptual flowheet analyses of some of these processes are presented. A tentative processing sequence for the removal of the actinides 1 s $\mathrm{dic}$ cussed. 
10. APPEDIDIXS

10.1 Appendix A: Hazard Index Values for the Hajor Components of Unprocessed Spent Fuels from the

\section{Principal Reactor Types}




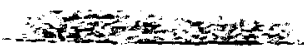

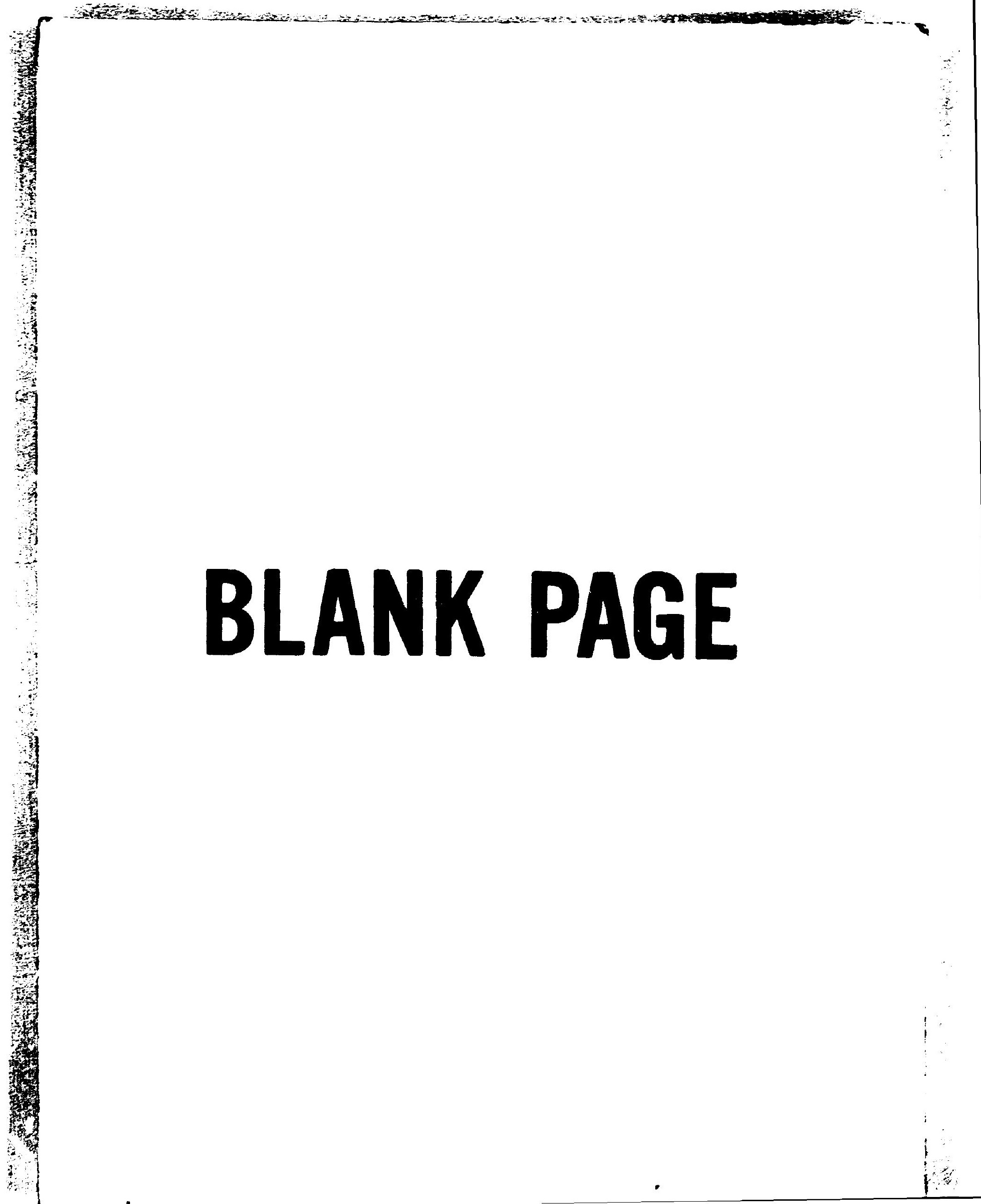




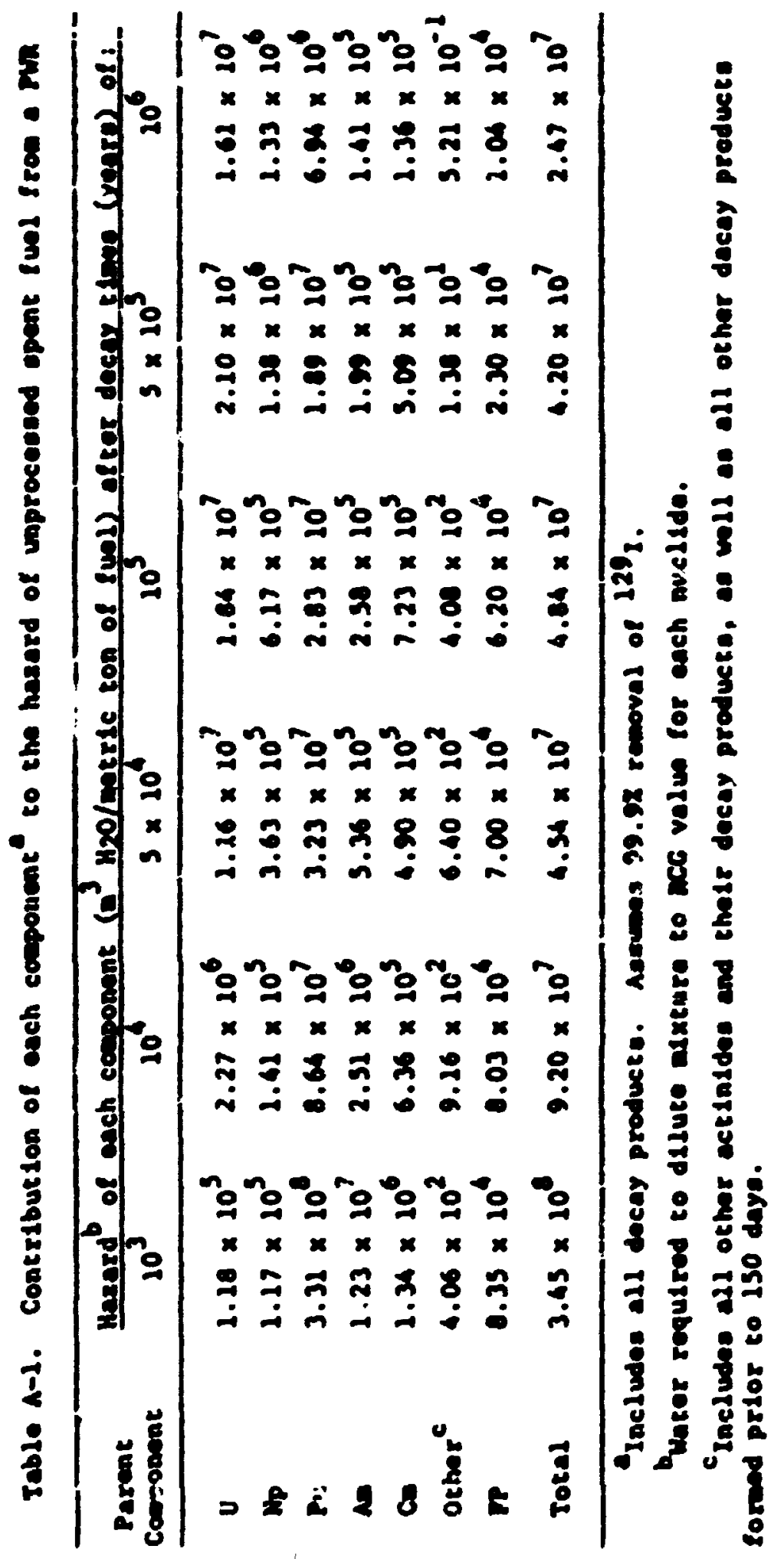


Table A-2. Coatrlbut lon of each component to the hasard of unprosesend. blended epeat fuelb fren a Mrit utilising equllibrius plutontiv reeycle

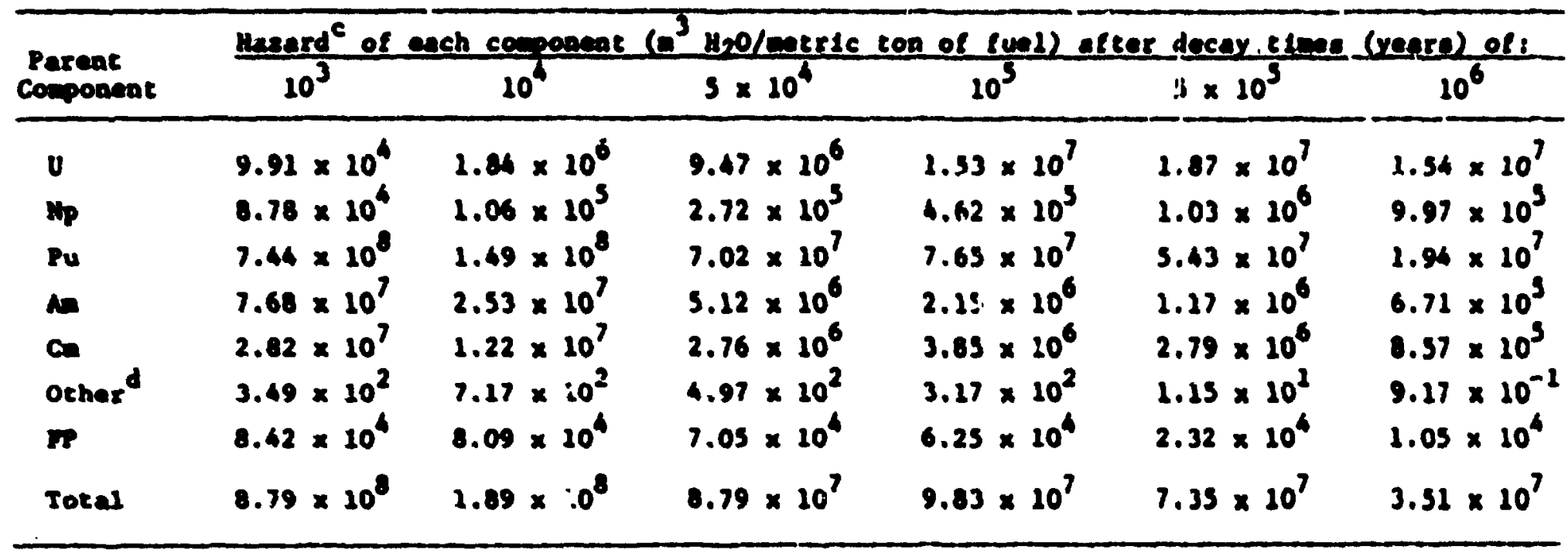

Includee all decay producte. Aasume 99.92 removal of 129 l.

bulended tual lo ewo-thlide PMr-U and ope-thlrd PM-Pu.

Gater required to dilute alxture to Mcc velu for each nuclide.

Iacludee ell other ectinides and thesr decay products, a woll as all other decay producte formed prior to 90 daye. 
Table A-3. Coatribution of each component to tha haserd of unprocenead apent fuel from an Lusks

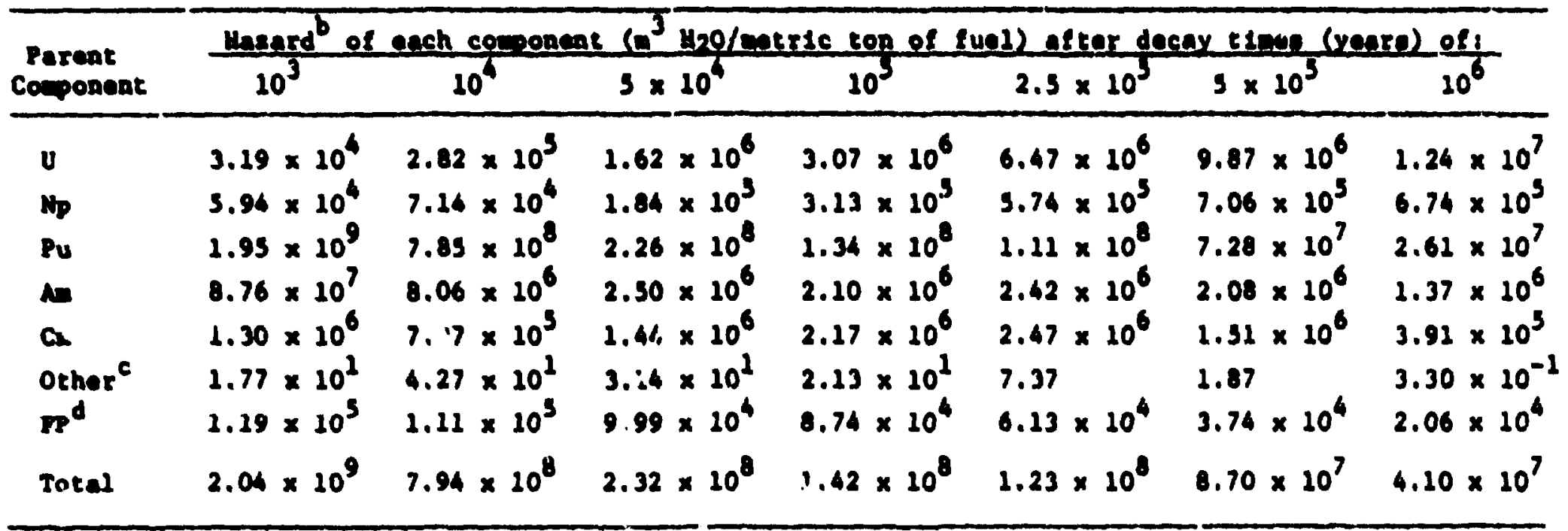

Includes all decay producta.

buter required to dilute a mixture to the RCG for cach nuclide.

CIncludes all other actinldae and thatr decay prodinte, and all dacay projucte trised prior to 90 daye.

daaume prtor removal of 99.98 of lodine and 1008 of trittum and noble caces. 
Table A-4. Contribution of each component" to the hazard of unproceesed apont tuel from on HTGR

\begin{tabular}{|c|c|c|c|c|c|c|c|}
\hline $\begin{array}{l}\text { Parent } \\
\text { Component }\end{array}$ & \multicolumn{7}{|c|}{ 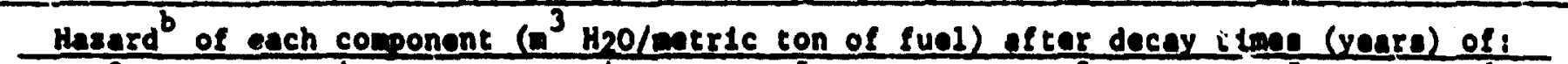 } \\
\hline Th & $3.86 \times 10^{6}$ & $3.94 \times 10^{6}$ & $3.59 \times 10^{6}$ & $3.44 \times 10^{6}$ & $3.25 \times 10^{0}$ & $3.18 \times 10^{6}$ & $3.17 \times 10^{6}$ \\
\hline $\mathbf{P a}$ & $2.48 \times 10^{6}$ & $2.05 \times 10^{i}$ & $8.80 \times 1.0^{5}$ & $3.07 \times 10^{5}$ & $1.58 \times 10^{4}$ & $1.28 \times 10^{3}$ & $1.42 \times 10^{2}$ \\
\hline $\mathbf{U}$ & $1.08 \times 10^{8}$ & $8.10 \times 10^{8}$ & $3.80 \times 10^{9}$ & $2.12 \times 10^{9}$ & $1.96 \times 10^{9}$ & $1.10 \times 10^{9}$ & $2.65 \times 10^{8}$ \\
\hline$N_{p}$ & $5.40 \times 10^{5}$ & $6.49 \times 10^{3}$ & $1.67 \times 10^{6}$ & $2.84 \times 10^{6}$ & $3.21 \times 10^{6}$ & $6.42 \times 10^{6}$ & $6.12 \times 10^{6}$ \\
\hline Pu & $2.93 \times 10^{7}$ & $2.41 \times 10^{7}$ & $1.01 \times 10^{8}$ & $1.53 \times 10^{8}$ & $1.73 \times 10^{8}$ & $1.06 \times 10^{8}$ & $2.75 \times 10^{7}$ \\
\hline An & $3.18 \times 10^{6}$ & $1.00 \times 10^{6}$ & $1.83 \times 10^{5}$ & $3.45 \times 10^{4}$ & $2.54 \times(1)^{4}$ & $2.69 \times 10^{4}$ & $2.32 \times 10^{4}$ \\
\hline Cm & $8.91 \times 10^{5}$ & $3.66 \times 10^{5}$ & $3.12 \times 10^{4}$ & $3.75 \times 10^{4}$ & $4.34 \times 11^{4}$ & $2.82 \times 10^{4}$ & $9.59 \times 10^{3}$ \\
\hline Other ${ }^{c}$ & $5.32 \times 10^{2}$ & $1.14 \times 10^{1}$ & $4.32 \times 10^{-2}$ & $3.08 \times 10^{-2}$ & $4.03 \times: 2^{-2}$ & $4.29 \times 10^{-2}$ & $3.68 \times 10^{-2}$ \\
\hline & $2.02 \times 10^{5}$ & $1.96 \times 10^{5}$ & $1.76 \times 10^{5}$ & $1.53 \times 10^{5}$ & $1.04 \times 10^{5}$ & $6.02 \times 10^{4}$ & $2.92 \times 10^{4}$ \\
\hline Total & $1.61 \times 10^{3}$ & $3.70 \times 10^{8}$ & $2.31 \times 10^{9}$ & $4.41 \times 10^{9}$ & $4.56 \times 10^{9}$ & $2.70 \times 10^{9}$ & $6.90 \times 10^{8}$ \\
\hline
\end{tabular}

ancludes all decay producte. Does not include the apant ${ }^{233} \mathrm{U}$ rencycle fuel.

Weter required to dilute alxture to the RCG for each nuclide. 365 daye.

CIncludes all cther actinides and thatr decay products, and all decay producta formed prior to

dasumes prior rasoval of 99.98 of lodine and $100 \mathrm{x}$ of iritium and noble sases. 


\subsection{Appendix B: Calculation of the Hazard Inderses of Oraniug kinerals}

Pitchblende aineral, wich occurs principally in South Africa and Canade, represeats the upper lintt o: radiological coxicity of maturally occurring afnerals on the basis of hazard toder values. Carnotice ore found in deposits on the Colorado Plateau of the vestern Dnited States was selected as typical of considerably louer-content uraniun ores of fairly indespread occurrence. These two ainerals reflect the approximate renge of ureniun concentrations found in all uraniu afwerals of econonc value and major radiological significance.

The hazard index values for the ores were calculated from the follcw Ing data:

(1) The volue of vater needed to dilute $1 \mathrm{~g}$ of natural uranil in equilibriun with :ts daughters to $10 \mathrm{CTh} 20$ values is $15.1 \mathrm{~m}$, as calculated usirs the ORIGal code.

$\begin{array}{lcc}\text { Pitchblende } & 9 & 70 \\ \text { Carnotite } & 3 & 0.2\end{array}$

The density of pitchblende anerais ranges from about $t$ to about $9 \mathrm{~g} / \mathrm{cc}$, and the uraniun content ary vary from about 40 to $; 0 \mathrm{z}$. Siallar variation in properties can occur for carnotite einerals. Density values and uraniu content values vere selected to represent upper linits of toxicity for pitchblende and the relatively high-grade carnotite ore. Only one algnificant figure was used for the calculated hazard index because of the ucertainties regarding the aineral property values.

(3) Hazard inderes (HI) values were calculated as follows:

HI (pitchblende) $=9 \mathrm{~g} / \mathrm{cm}^{3} \times 0,7 \times 1: .1 \mathrm{~m}^{3 / 8} \times 10^{6} \mathrm{~cm}^{3} / \mathrm{m}^{3}$ $-1 \times 10^{8}$

HI (carnotite) $=3 \mathrm{~g} / \mathrm{cm}^{3}: 0.002 \times 15.1 \mathrm{~m}^{3 / 8} \times 106 \mathrm{~cm}^{3} / \mathrm{a}^{3}$ $-1 \times 1 c^{5}$ 
10.3 Appendix C: Pilative Contributions of the Major Componts of High-Level haste fron Couventional Reprocessing

of Oraniun-Plutonitu Fuels and from Assuned

Secondary Processing of the Waste 
Tatle C-1. Relative contributione of the componente of high-level waste to the hasard Index for wates from uranium-plutonium fuelo after conventional reproceseins

\begin{tabular}{|c|c|c|c|c|c|c|c|c|}
\hline $\begin{array}{l}\text { Type } \\
\text { of } \\
\text { Waste }\end{array}$ & $\begin{array}{l}\text { Decay } \\
\text { T1me } \\
\text { (years) }\end{array}$ & $\frac{\text { Relat }}{u}$ & oncribu & to $t$ & hese & the & 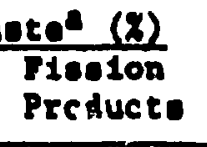 & $\begin{array}{l}\text { Heserd Index } \\
\text { of wagted } \\
\left.\text { ( } \mathrm{m}^{3} \mathrm{H}_{2} \mathrm{O} / \mathrm{m}^{3} \text { wasto }\right)\end{array}$ \\
\hline \multirow[t]{4}{*}{ PWR-U } & $10^{3}$ & $N 11^{b}$ & 0.8 & 11 & 79 & 9 & 0.5 & $2.74 \times 10^{8}$ \\
\hline & $10^{4}$ & 0.3 & 3 & 11 & 67 & 17 & 2 & $6.73 \times 10^{8}$ \\
\hline & $10^{5}$ & 5 & 33 & 8 & 14 & 38 & 3 & $3.34 \times 10^{7}$ \\
\hline & $10^{6}$ & 5 & 77 & 2 & 8 & 8 & 0.6 & $3.07: 10^{7}$ \\
\hline \multirow[t]{4}{*}{ PWR-Pu } & $10^{3}$ & N11 & 0.08 & 3 & 71 & 26 & 0.1 & $1.92 \times 10^{2}$ \\
\hline & $10^{4}$ & 0.02 & 0.3 & 2 & 65 & 31 & 0.2 & $6.79 \times 10^{8}$ \\
\hline & $10^{5}$ & 1.1 & 7 & 6 & 31 & S5 & 0.9 & $1.23 \times 10^{8}$ \\
\hline & $10^{6}$ & 2.8 & 37 & 4 & 25 & 32 & 0.4 & $4.79 \times 10^{8}$ \\
\hline \multirow[t]{4}{*}{ LMPBR } & $10^{3}$ & $\mathbf{N 1 1}$ & 0.06 & 10 & 89 & 1 & 0.1 & $1.26 \times 10^{9}$ \\
\hline & $10^{4}$ & 0.01 & 0.6 & 30 & 62 & 6 & 0.9 & $1.53 \times 10^{8}$ \\
\hline & $10^{5}$ & 0.3 & 6 & 12 & 39 & 40 & 2 & $6.30 \times 10^{7}$ \\
\hline & $10^{6}$ & 2 & 26 & 5 & 52 & 15 & 0.8 & $3.12 \times 10^{7}$ \\
\hline
\end{tabular}

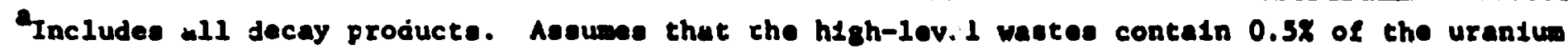
ard plutoniva, $0.1 X$ of the lodine, and trone of the tritlum and rare gases fron the opent fuel.

bitl 1o defined ac lean than $5 \times 10^{-3}$. 
Table C-2. Relative contributson of actinides and flesion products to the hazard Index of high-level wate from urantum-olutontum fuale after econdary procensinga

\begin{tabular}{|c|c|c|c|c|c|c|c|c|}
\hline \multirow{2}{*}{$\begin{array}{l}\text { Decay } \\
\text { tlme } \\
\text { (years) }\end{array}$} & \multirow{2}{*}{$\begin{array}{l}\text { Type } \\
\text { of } \\
\text { waste }\end{array}$} & \multirow{2}{*}{$\begin{array}{l}\text { Percent of } \\
\text { pitchblende } \\
\text { hazardb }\end{array}$} & \multicolumn{6}{|c|}{$\begin{array}{c}\text { Percent contribution to total haserd Index of the } \\
\text { hyeh-1ovel weete }\end{array}$} \\
\hline & & & $\mathbf{u}$ & Np & Pu & Am & $\mathrm{Cm}$ & $\begin{array}{l}\text { Fioelon } \\
\text { Product }\end{array}$ \\
\hline \multirow[t]{3}{*}{$10^{3}$} & PWR-U & 5 & 0.04 & 2 & 61 & 5 & 0.5 & 31 \\
\hline & PWR-Pu & 5 & 0.04 & 2 & 28 & 29 & 11 & 31 \\
\hline & LMFER & 5 & 0.01 & 0.7 & 48 & 22 & 0.3 & 29 \\
\hline \multirow[t]{3}{*}{$10^{4}$} & PWR-U & 2 & 2 & 5 & 32 & 2 & $0 .:$ & 59 \\
\hline & PWR-Pu & 2 & 1 & 4 & 11 & 18 & 9 & 58 \\
\hline & LMFBR & 2 & 0.1 & 2 & 39 & 4 & 0.4 & 35 \\
\hline \multirow[t]{3}{*}{$10^{5}$} & PWR-U & 2 & 25 & 24 & 11 & $0 . ?$ & 0.6 & 49 \\
\hline & PWR-Pu & 2 & 13 & 20 & 7 & 2 & 3 & 54 \\
\hline & LWFBR & 1 & 2 & 13 & 11 & 2 & 2 & 71 \\
\hline \multirow[t]{3}{*}{$10^{6}$} & PWR-U & 2 & 17 & 69 & 4 & 0.1 & 0.1 & 11 \\
\hline & PWR-Pu & 1 & 19 & 62 & 2 & 1 & 1 & 13 \\
\hline & LMFBR & 1 & 17 & 47 & 4 & 2 & 0.6 & 29 \\
\hline
\end{tabular}

after secondary proceestug, the percentage romovale from opent fuel elemente were aseumed to be as follows: PWR-U $-99.9 \% \mathrm{NP}, 99.95 \% \mathrm{Pll}$, and $99.92 \mathrm{Am}, \mathrm{Cm}$, and $\mathrm{I}$

PWR-Pu - same as PWR-U except $99.99 \%$ of Pu was removed

LWFBR - same as PWR-Pu

${ }^{b}$ (Hazard Index of high-level waste $z$ hazard Indax of pltchblende) $x 100$. (Hazard Index of pitchblende) $=1.0 \times 10^{8} \mathrm{~m}^{3}$ of $\mathrm{H}_{2} \mathrm{O} / \mathrm{m}^{3}$ of mineral. 
10.4 Appendix D: Relative Contribution of Each Long-Lived Fission Product to the Total Hazard Index of Pfssion Products

Ii $\mathrm{BI}_{\mathrm{a}} \mathrm{h}$-Level Wastes 
Table D-1. Relative contribution of each iong-1ived fiesion product to the total hazard index of figsion producte in high-level wates from the principal types of reactor fuelo

\begin{tabular}{|c|c|c|c|c|c|c|c|c|c|}
\hline $\begin{array}{l}\text { Decay } \\
\text { t1re } \\
\text { (yeara) }\end{array}$ & $\begin{array}{c}\text { Type } \\
\text { of } \\
\text { waste }\end{array}$ & $\frac{\text { Cor }}{93 \mathrm{zr}}$ & $\frac{\text { ution }}{3 \mathrm{mb}^{\mathrm{b}}}$ & $\frac{c o c a l}{99} \mathrm{Tc}$ & $\frac{\operatorname{ard} \text { in }}{107_{\text {Pd }}}$ & & $-\ldots$ & $\frac{\ln (\gamma)}{\text { other }}$ & $\begin{array}{l}\text { Total } \\
\text { hazard } \\
\text { Index of } \\
\text { fionion } \\
\text { producted }\end{array}$ \\
\hline $10^{3}$ & $\begin{array}{l}\text { PWR-U } \\
\text { PWL-PU } \\
\text { LWRBR } \\
\text { HTGR }\end{array}$ & $\begin{array}{l}3 \\
2 \\
2 \\
4\end{array}$ & $\begin{array}{l}6 \\
4 \\
4 \\
8\end{array}$ & $\begin{array}{l}86 \\
84 \\
77 \\
83\end{array}$ & $\begin{array}{l}0.1 \\
0.3 \\
0.2 \\
0.02\end{array}$ & $\begin{array}{l}1 \\
1 \\
1 \\
1\end{array}$ & $\begin{array}{r}3 \\
6 \\
10 \\
3\end{array}$ & $\begin{array}{l}1 \\
2 \\
4 \\
0.3\end{array}$ & $\begin{array}{l}1.47 \times 10^{6} \\
1.51 \times 10^{6} \\
1.40 \times 10^{6} \\
1.18 \times 10^{6}\end{array}$ \\
\hline $10^{4}$ & $\begin{array}{l}\text { PWR-U } \\
\text { PWR-PU } \\
\text { LWTBR } \\
\text { UTGR }\end{array}$ & $\begin{array}{l}3 \\
2 \\
2 \\
4\end{array}$ & $\begin{array}{l}6 \\
4 \\
4 \\
8\end{array}$ & $\begin{array}{l}86 \\
85 \\
80 \\
83\end{array}$ & $\begin{array}{l}0.1 \\
0.3 \\
0.3 \\
0.02\end{array}$ & $\begin{array}{l}1 \\
1 \\
2 \\
1\end{array}$ & $\begin{array}{r}3 \\
6 \\
13 \\
13\end{array}$ & $\begin{array}{l}\text { N11 } \\
N 11 \\
N 11 \\
N 11\end{array}$ & $\begin{array}{l}1.42 \times 10^{6} \\
1.45 \times 10^{6} \\
1.31 \times 10^{6} \\
1.15 \times 10^{6}\end{array}$ \\
\hline $10^{5}$ & $\begin{array}{l}\text { PWR-U } \\
\text { PWR-Pu } \\
\text { LYF'BR } \\
\text { HTGR }\end{array}$ & $\begin{array}{l}4 \\
3 \\
2 \\
5\end{array}$ & $\begin{array}{r}7 \\
5 \\
5 \\
10\end{array}$ & $\begin{array}{l}93 \\
82 \\
75 \\
79\end{array}$ & $\begin{array}{l}0.2 \\
0.3 \\
0.3 \\
0.03\end{array}$ & $\begin{array}{l}1 \\
2 \\
2 \\
1\end{array}$ & $\begin{array}{r}5 \\
8 \\
16 \\
4\end{array}$ & $\begin{array}{l}N 11 \\
N 11 \\
N 11 \\
N 11\end{array}$ & $\begin{array}{l}1.10 \times 10^{6} \\
1.13 \times 10^{6} \\
1.03 \times 10^{6} \\
9.00 \times 10^{6}\end{array}$ \\
\hline $10^{6}$ & $\begin{array}{l}\text { PWR-U } \\
\text { PWR-Pu } \\
\text { LMFBR } \\
\text { HTGR }\end{array}$ & $\begin{array}{r}14 \\
10 \\
7 \\
18\end{array}$ & $\begin{array}{l}29 \\
20 \\
13 \\
35\end{array}$ & $\begin{array}{l}26 \\
24 \\
17 \\
22\end{array}$ & $\begin{array}{l}1 \\
2 \\
1 \\
0.1\end{array}$ & $\begin{array}{l}8 \\
9 \\
8 \\
7\end{array}$ & $\begin{array}{l}22 \\
36 \\
54 \\
18\end{array}$ & $\begin{array}{l}N 11 \\
N 11 \\
N 11 \\
N 11\end{array}$ & $\begin{array}{l}1.80 \times 10^{5} \\
2.93 \times 10_{5}^{5} \\
2.44 \times 10^{5} \\
1.72 \times 10^{5}\end{array}$ \\
\hline
\end{tabular}

a

Assumes that 99.97 of the lodine was removed and no activation producte from the cladding.

b Short-lived but in equilibrium with $932 \mathrm{r}$.

Crimarily ${ }^{151} \mathrm{Sm}$.

$d^{3}$ of $\mathrm{H}_{2} \mathrm{O} / \mathrm{m}^{3}$ of waste. At 1000 yeara, the hazard Indax value of the long-11ved fiasion producta is about 1 to $1.5 \%$ of the value for pltchblende. 


\subsection{Appendix E: Preparation of Synthetic Hiaste Solutions}

Waste solutious were syathetically prepared by aixing nitric acid solutions of nitrate salts of nonradioactive isotopes of fission product elements. The quantities of fission product elemenis were based on the quantities of fission products that were calculated by the ORIGEN code for typical LGR fuel (no Pu recycle) irradiated to 33,000 MNd/metric ton. The fission product content of the waste was based on a fuel reprocessing tine of 160 days and storage of the waste for five years after reprocessing. The fission products from 1 wetric ton of this fuel were assuned to be present in 3100 liters of $2 \underline{M} \mathrm{HWO}_{3}$. The volume, acid concentration, and fission product content values correspond to approximately those expected for the feed solution to the coextraction colum (firsi: TBP cycle) in a Purex plant. The fission product and acid concentrations in the original Purex feed were chosen because the formation of solids and precipitates in the subsequent solvent extraction steps from which the highlevel wastes if generated car be also studied.

The approach to preparing the synthetic waste solutions was to wake up individual solutions of each element and then combine appropriate volumes of the solutions to obtain the desired concentrations. Sone of the elements are either insoluble or only slightly soluble in nitric acid, and tnis complicates the preparation. In these cases, the solutions were freshly prepared prior to use, whereas solutions conposed of soluble elements were prepared and stored until needed. The synthetic waste elements, their desired quantities in the synthetic waste, the starting cowpound, and the method used to dissolve the individual elements in nitric acid solution are given in Table E-1. The solutions containing tin and ant2. mony are not stable with regard to precipitaticn and thus wst be prepared tmediately before combining with the ott.er solutions.

The following procedure was used to prepare 15-11ter batches of synthetic solutions containing nonredinsctive forms of the fission product elements:

(1) Add proper voluses of individusl solutions of I, Br, Mo, $\mathrm{Zr}$, As, $\mathrm{Sb}, A 8$, Gd, and $\mathrm{Eu}$ to a stock solution containing the $\mathrm{Sr}, \mathrm{La}$, Sm, In, Cd, Cs, Pr, Se, Ce, Ba, Te, Nd, and Y. 
(2) Ad proper volunes of $\mathbf{W}, \mathrm{Wh}, \mathrm{Tu}, \mathrm{Pd}$, and Sa solutions to the solutios prepared in (1). Precipitation will occur; however, cost of the solide will rediesolve on stirring the solution for bout $1 \mathrm{hr}$.

(3) Filter the solution. A enell quentity of gray-colored solids is separated. The composition of the solids is not precisely known at the present tine; however, they appear to consist prianrily of tin and entimony.

Hethods for preparing agathetic wate solutions will continue to be investigated, particularly in regard to the formation of precipitates and collotds. These studies will provide valuble informating concerning the conditions and concentrations favoring formation of precipitates, and the actinide content of these precipitates, if any. 
101

Toble E-1. Preparation of syatbetic vaste solutions

\begin{tabular}{|c|c|c|c|}
\hline Elenent & $\begin{array}{l}\text { Qumeity } \\
\text { (g/liter) }\end{array}$ & Conpound & Benarles \\
\hline Sr & 0.263 & $\operatorname{Sr}\left(\mathrm{OO}_{3}\right)$ & Discolved in water \\
\hline In & 0.0004 & $\operatorname{In}\left(\log _{3}\right)_{3} \cdot 4$ & Diceolved in 1 $\underline{\mathrm{moO}_{3}}$ \\
\hline cd & 0.027 & Netal & Discolred in $8 \underline{\mathrm{M}} \mathrm{EDO}_{3}$ \\
\hline Cs & 0.780 & $\mathrm{CanO}_{3}$ & Discolved in 0.1 $\underline{\mathrm{BiO}} 3$ \\
\hline se & 0.016 & $\mathrm{~B}_{2} \mathrm{SeO}_{3}$ & 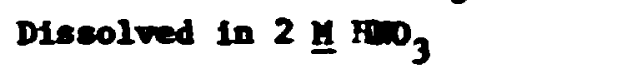 \\
\hline Ba & 0.536 & $\mathrm{Ba}\left(\mathrm{OO}_{3}\right)_{2}$ & Discolved in wher \\
\hline Te & 0.181 & Netal & Diesolved in $8 \mathrm{Y} \mathrm{ED}_{3}$ \\
\hline$y_{0}$ & 1.10 & $\left(\mathrm{mH}_{4}\right)_{6} \mathrm{Is}_{7} \mathrm{O}_{24} \cdot 4 \mathrm{~B}_{2} \mathrm{O}$ & Diesolved in $0.5 \mathrm{E} \mathrm{BDO}_{3}$ \\
\hline sa & 0.016 & Fetal, sranul, 30 mesh & $\begin{array}{l}\text { Diseolved in } 4 \text { i } \mathrm{B}_{3} \text {, no } \\
\text { hent, wo stirifis }\end{array}$ \\
\hline 18 & 0.019 & $\mathrm{ArOH}_{3}$ & Diseolved in water \\
\hline $\mathbf{z r}$ & 1.17 & $2 \pi 0\left(10_{3}\right)_{2} \cdot 24_{2} 0$ & Diesolved in $1 \underline{\mathrm{H}} \mathrm{ED}_{3}$ \\
\hline Br & 0.005 & $\operatorname{MansO}_{3}$ & Diesolved in water \\
\hline I & 0.086 & $\mathrm{ALO}_{3}$ & Diseolved in weter \\
\hline$\Delta$ & 0.00003 & netal & 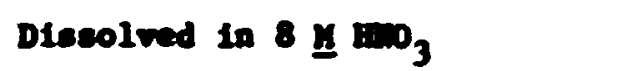 \\
\hline sb & 0.004 & Metal & Discolved in $8 \underline{E} \mathrm{ED}_{3}$ \\
\hline Pd & 0.456 & Hatal & $\begin{array}{l}\text { Discolved in } 8 \text { y En, added } \\
3 \text { drope BC1, bolled off } \\
\text { chloride }\end{array}$ \\
\hline $\boldsymbol{m}$ & 0.125 & netal & 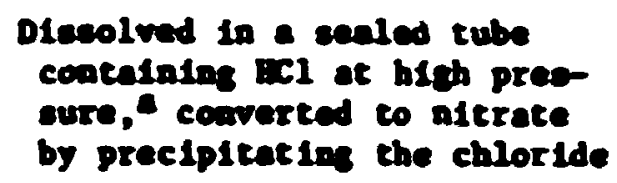 \\
\hline $\mathbf{b}$ & 0.107 & $\mathbf{a c l}$ & $\begin{array}{l}\text { Diesolved in weter, preclpt- } \\
\text { teted chlortde with } \mathrm{AdN}_{3}\end{array}$ \\
\hline su & 0.600 & $\operatorname{mec}_{3}$ & 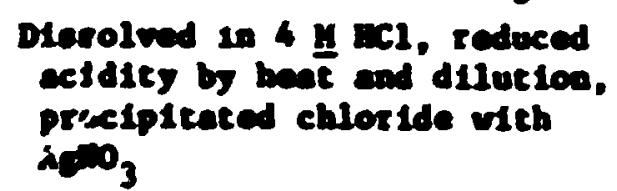 \\
\hline La & 0.410 & & Deseolved in weter \\
\hline $\mathbf{r}$ & 0.151 & & 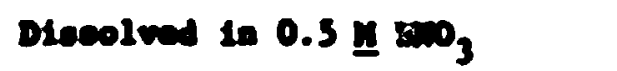 \\
\hline $\boldsymbol{u}$ & 1.32 & & Diecelved in $2.0 \mathrm{M} \mathrm{mog}_{3}$ \\
\hline Pr & $0.3 \times 6$ & $\operatorname{Pr}\left(0_{3}\right)_{3} \cdot 5 n_{2} 0$ & Desoolved is $1 \mathrm{M} \mathrm{Em}_{3}$ \\
\hline
\end{tabular}


Table E-1. (continued)

\begin{tabular}{|c|c|c|c|}
\hline Element & $\begin{array}{l}\text { Qumetity } \\
\text { (g/liter) }\end{array}$ & Cospound & Rewarks \\
\hline ce & 0.796 & $\operatorname{Ce}\left(\mathrm{m}_{3}\right)_{3} \cdot 6 \mathrm{H}_{2} \mathrm{O}$ & Dissolved In 1 ㄴ $\mathrm{HrO}_{3}$ \\
\hline Sa & 0.286 & $\sin _{2} 0_{3}$ & $\begin{array}{l}\text { Dissolved in } 12 \text { H } \mathrm{BDO}_{3} \text {, } \\
\text { evaporated to near dryness, } \\
\text { added water }\end{array}$ \\
\hline cd & 0.038 & $\operatorname{cd}_{2} \mathrm{O}_{3}$ & $\begin{array}{l}\text { Dissolved in } 12 \text { H } \mathrm{HLO}_{3} \text {, } \\
\text { evaporated to nea- dryness, } \\
\text { added water }\end{array}$ \\
\hline Eu & 0.055 & $\mathrm{Eu}_{2} \mathrm{O}_{3}$ & $\begin{array}{l}\text { Dissolved in } 12 \text { M En: } \\
\text { evaporated to near dryness, } \\
\text { added vater }\end{array}$ \\
\hline $\mathrm{Tb}^{\mathrm{b}}$ & 0.0006 & & \\
\hline$D y^{b}$ & 0.0004 & & \\
\hline Ho & 0.00003 & & \\
\hline $\mathbf{E x}^{\mathbf{b}}$ & 0.00001 & & \\
\hline Ge & 0.00012 & Ontited & \\
\hline $\mathbf{M b}$ & 0.000008 & Onitted & \\
\hline Tc & 0.271 & Onitced & \\
\hline$P=$ & 0.009 & Ontited & \\
\hline
\end{tabular}

Thodiu netal was dissolved by persomel in the ORIL Analytical Division.

brare-earth elements were not used. 


\section{REFEREACES}

1. High-Level Radioactive Uaste Managenent Mrematives, MASH-1297, U. S. Atonic Energy Coldssion (Fay 1974).

2. H. C. Claiborne, Neutron-Induced Trmsination of Bigh-Level Radioactive Hastes, ORViL-TH-3964 (Decenser 1972).

3. J. H. Bartlett, L. A. Bray, L. L. Burger, R. E. Burns, and J. L. Ryan, Feasibility Evaluation and RCD Progran P1an for Transuranic Partitioning of High-Level Puel Reprocessing Wastes, Bul-1776, dattelle Northwest Laboratory (Novenber 1973).

4. J. O. Blomeke, J. P. Michols, and W. C. McClain, Minaging Radioactive Wastes," Physics Today 26(8), 36-42 (1973).

5. H. J. Bell, ORIGEN - The ORIL Isotope Generation and Depletion Code, ORNL-4628 (May 1973).

6. K. E. LaVerne, Appendix I of Ref. 2.

7. Aqueous Processing of LYFBR Fuels - Technical Assesenent and Experiental Progran Definition (compiled and edited by the Staff of the Chendcal Technology Division), Orul-4436 (June 1970).

8. Reprocessing of Yankee Reactor Puel at Nuclear Fuel Services, Inc., Vest Valley Factlity (prepared by Fuels Reprocessing Brach, USAX, Savanah River Operations (ffice), Spo-124 (Oct. 21, 1968).

9. W. W. Schultz and G. E. Benedict, Meptuniu-237 Production and Pecone포, ARC, Critical Review Series, U.S.A.E.C. Office of Information Services (1972).

10. R. E. Leuze and M. H. Lloyd, "Processing Hithods for the Racovery of Transplutoniu Elements," in Process Cheidetry, Vol. 4, Perzenon, New York, 1969.

11. R. G. Baxiez, Actinide Propertles and Yachode of Product10n, DP-1269, R. I. du Pont de Renoure and Co. (Decenber 1972).

12. E. J. theelwright and F. P. Doberts, The Uce of Altermatese DiPA cad IIA Cation-Exchange Plowheets for the SI Diterieons locown of ad Purification of $P$, $A$, and $C$, Bill-1072, Batedie Dorthmet Loboratory (July 1968).

13. S. J. Beard and R. L. Moore, "Large Scale Recovery and Purificacton of P1setion Produces," In Procene Chenterry. Vo1. 4. Pergenon, Vew York, 1969. 
14. J. A. Telley, Ion Exchane Process for Separating Merictiv and Curlue from Irrediated Plutonle, DP-1308, E. I. du Poat de Rewours ad Co. (Woverber 1972).

15. B. Weaver and F. A. Tappelam, "Preferential Extraction of Lanthenides or Trivaleat Actinldes by Hononcidic Orgenophosphonates from Carborylic Acids and froe Carboxylic and Aninopolyacetic Acids,"

J. Inorg. Nucl. Chem. 30, 263-72 (1968).

1i. B. Wesver and F. A. Kappelman, Talspeak: A llew Hethod of Separacing nericiu and Curive froe Lenthentes by Extraction froe a squeous Solution of Afioopolracetic Acid Con lex with a Honoacidic Phosphate or Prosphouate, 0.16-3559 (August 1964).

17. Z. Tolarik, G. Toch, B. H. Tuesel, and J. Pritsch, Separation of

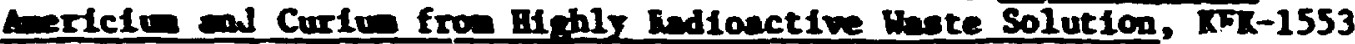
(1972).

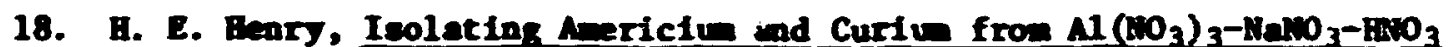
Solutions by Batch Exraction with Tributyl Phosphate, DP-972, E. I. du Poat de Benours and Co. (August 1965).

19. D. A. Orth, J. M. Mckibben, W. E. Prout, and W. C. Scotten, "Isolation of Trensplutoniw Elements," Pp. 534-55 in Pzoceedings of the International Solvent Extraction Conference, The Baque, Soc. of Chen. Ind. (1971).

20. H. C. Thompen, Distribution of Selccted Lanthanides and Actinides Between 302 TIP In D-Paraffin ad Various Hetel Hitrate Solutions, DP-1336, E. 1. du Pont de Nenours and Co. (Novenber 1973).

21. M. A. Llogi "An Anion Exchenge Procese for Americlu-Curiun Recovery from Plutonio Process Waste," Mucl. Scl. Eng. 17, 452-56 (1963).

22. C. Boehlin, H. J. Borm, ad W. Heinlender, "The Isolation of ${ }^{242} \mathrm{Ca}$ from meutroo-Irrediated 241,n," Rediochte. Acte 10, 85-91 (1968).

23. B. Waver, "Solvent Ixtrection in the Separation of Rare Earthe and Trivalent Actinidos," pp. 189-277 in Ion Erehme end Solvant Butrac-

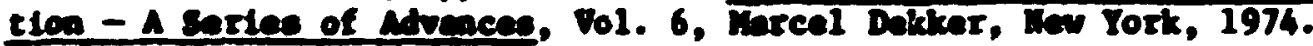

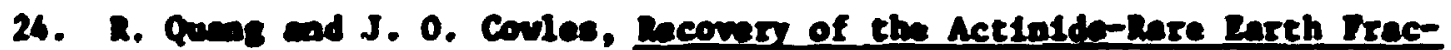

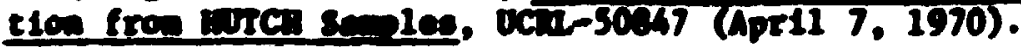

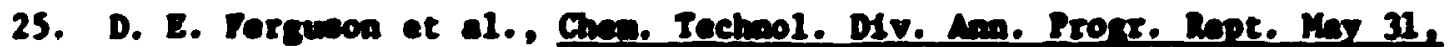
196. Ous-3945, pp. 170-75.

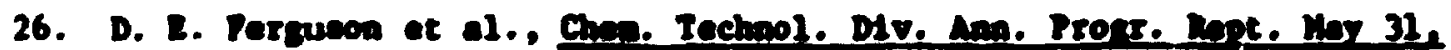
1968, 0sil-4272, pp. $103-8$. 
27. U. E. Unger et al., Aqueous Fuel Reprocessing Quarterly Report for Period Ending Septe-ber 30, 1973, ORN-'m-4394 (February 1974), pp. 13-20. (Avallable from the U. S. Atonic Energy Comission, Technical Information Center, P. O. Box 62, Oak Ridge, Ti 37830).

28. H. E. Unger et al., Aqueous Fuel Reprocessing Quarterly Report for Period Ending Dece ber 31, 1973, ORdi-T7-4488 (June 1974), Pp. 9-18. (Available from the U. S. Atonic Energy Comission, Technical Information renter, P. O. Box 62, Oak Ridge, Ty 37830).

29. H. Ochsenfeld, H. Schnieder, and S. Theiss, Aqueous Reprocessing of Fast Breeder Fuel Elenents: Comon Extraction and Separation of Macroguantities of Plutonile and Uranile in the Purex Process, EURFNR-888 (October 1970).

30. Liquid Metal Fast Bresder Reactor Progran Plan, Element 8-Fuel Recycle, WhSH-1108, U. S. Aivalc Energy Colissior (Decenter 1972).

31. R. I. Newan, "The Barnwell Nuclear Fuel Plant," Nucl. Eng. Intern. 17, 938-41 (1972).

32. D. S. Webster et al., Ches!cal Engineering Division Fuel Cycle Techulology Quarterly Report, Januart-Karch 1971, All-7799, Argonne National Laboratory (July 1971).

33. G. Roch, W. Ochsenfeld, and E. Schwind, Flowsheet Studies on the Processing of Pluconiu Puels by Solvent Extraction, KTK-990 (May 1969).

34. J. M. Mckibben and J. E. Bercaw, Hydroxylentine Mitrate as a Plutoniu Reductant in the Purex Solvent Extraction Procese, DP-1248, E. I. du Pont de Newours and $C_{0}$. (January 1971).

35. R. L. Walser, The Hanford Purex P1ent Experience with Raductents, ARH-SA-69 (July 1970).

35. D. A. Orth, J. M. Mckibben, ad W. C. Schotten, "Progres; In Tributyl Phosphate Technology in the Sevennah RIver P1eat," pp. 514-33 in Proceedinge of the International Solvent Extraction Confercence, The Herve, soc. of Chein. Ind. (1971).

37. H. A. 6. Mckay et al., Solvent Extrection Choptetry of latale (Proceedfage of the Intermational Conference on the Solvent Extrection Chendetry of Metals, Barme11), Macendilen, Hew York, 1965.

38. G. P. Dest, E. Hasford, and H. A. C. Mclny, "Tr1-n-Lutyl Phosphate as an Extracting Solvent for Inorganic Mitrates - 'JII. Trivalent Actint de Hitrates," J. Inorg. Hucl. Chem. 12, 136-40 (195!!). 
39. T. V. Bealy, "The Reaction of Nitric Acid with Forealdehyde and with Fornic Acid and Its Application to the Renoval of Mitric Acid fron Bfxtures," J. Appl. Chen. 8, 553-561 (1958).

40. H. Bahr, The Extraction Behavior of Neptumiun in the Reprocessing of Irradiated Fuels by the Purex Process, RTK-797 (Novenber 1968). 